\title{
Germany: 2007 Article IV Consultation-Staff Report; Staff Supplement; Public Information Notice; and Statement by the Executive Director for Germany.
}

Under Article IV of the IMF's Articles of Agreement, the IMF holds bilateral discussions with members, usually every year. In the context of the 2007 Article IV consultation with Germany, the following documents have been released and are included in this package:

- $\quad$ The staff report for the 2007 Article IV consultation, prepared by a staff team of the IMF, following discussions that ended on December 10, 2007, with the officials of Germany on economic developments and policies. Based on information available at the time of these discussions, the staff report was completed on January, 30, 2008. The views expressed in the staff report are those of the staff team and do not necessarily reflect the views of the Executive Board of the IMF.

- A staff supplement of February, 20, 2008 updating information on recent developments.

- $\quad$ A Public Information Notice (PIN) summarizing the views of the Executive Board as expressed during its February, 22, 2008 discussion of the staff report that concluded the Article IV consultation.

- A statement by the Executive Director for Germany.

The document listed below has been or will be separately released.

\section{Selected Issues Paper}

The policy of publication of staff reports and other documents allows for the deletion of market-sensitive information.

To assist the IMF in evaluating the publication policy, reader comments are invited and may be sent by e-mail to publicationpolicy@imf.org.

$$
\begin{gathered}
\text { Copies of this report are available to the public from } \\
\text { International Monetary Fund • Publication Services } \\
70019^{\text {th }} \text { Street, N.W. • Washington, D.C. } 20431 \\
\text { Telephone: (202) 623-7430 • Telefax: (202) 623-7201 } \\
\text { E-mail: publications@imf.org • Internet: http://www.imf.org }
\end{gathered}
$$

Price: $\$ 18.00$ a copy

\section{International Monetary Fund Washington, D.C.}





\section{INTERNATIONAL MONETARY FUND}

\section{GERMANY}

\section{Staff Report for the 2007 Article IV Consultation}

Prepared by the Staff Representatives for the 2007 Consultation with Germany

Approved by Michael Deppler and G. Russell Kincaid

January 30,2008

\section{Executive Summary}

Though strengthened by far-reaching reforms, the economy faces a severe test. The achievements are reflected in strong employment gains, a sound fiscal position, and robust competitiveness. GDP growth in 2007 was solid at 2.5 percent. However, the moderation of the global economic cycle has coincided with heightened financial tensions alongside a pause in the domestic reform process. GDP growth is projected to slow to 1.7 percent in 2008, but the greatly increased uncertainties impart substantial downside risks. To protect against these risks and to consolidate the gains achieved, the policy recommendations center on ways to foster a resilient financial sector, while raising the growth potential and securing fiscal sustainability.

Strengthening the financial sector's stability and efficiency requires policy attention. The immediate priorities are preserving the integrity of the financial system and maintaining economic confidence. However, significant medium-term challenges remain. Bank restructuring consistent with international financial integration is necessary to ensure that unviable banks do not take excessive risks. Staff also proposed a bank resolution policy to permit prompt action while maintaining incentives for prudent management. To increase accountability in banking supervision, the authorities are working to reduce overlap in responsibilities and improve coordination between BaFin, the regulator, and Bundesbank. Further corporate governance reforms are needed for capital market and productivity growth.

Stepping up productivity remains key to sustaining growth. Economic performance in the current cycle has not yet been evidently stronger than in past upswings. The authorities recognized that continued buoyant performance will require addressing emerging skills shortages, and they stated their commitment to continued reduction of red tape and openness to foreign capital. Staff expressed concern that recent labor market measures, motivated by a concern for fairness, were a step back and could have adverse effects on employment and growth.

Further efforts are needed to bolster and reinforce commendable gains in fiscal outcomes. Staff agreed that the authorities' medium-term fiscal goals are appropriately ambitious but saw a need for additional measures to achieve these goals. The authorities were not persuaded that new measures were needed — or feasible — in the short term, but agreed that long-term sustainability would require attention, especially to further healthcare reform. 
Executive Summary. 1

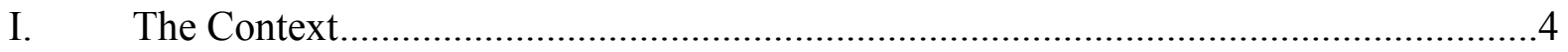

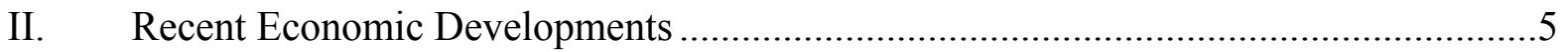

III. Outlook and Risks......................................................................................... 10

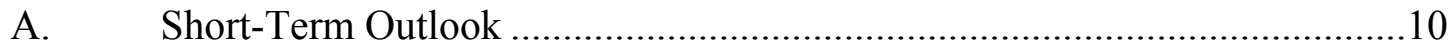

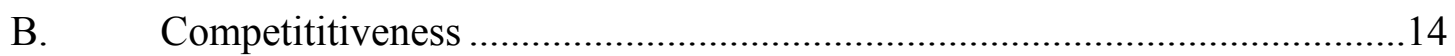

C. Medium-Term Outlook ........................................................................ 16

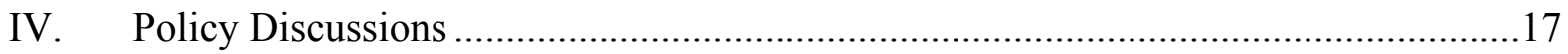

A. Strengthening Employment and Productivity ........................................18

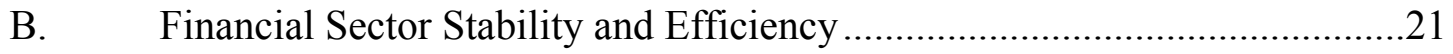

C. Strengthening Public Finances .............................................................26

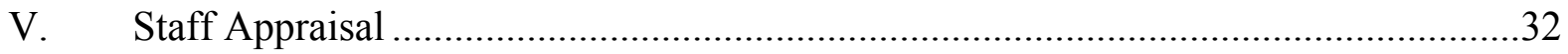

Boxes

1. Past Fund Policy Recommendations and Implementation........................................5

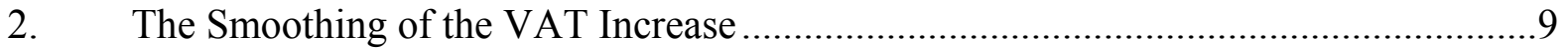

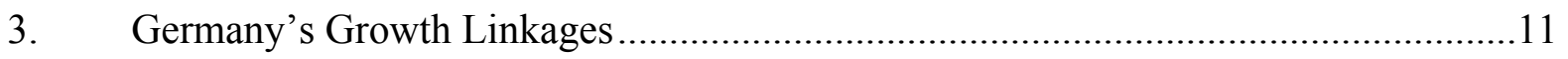

4. Growth Consequences of the Euro Appreciation …..............................................13

5. Alleviating Shortages of Skilled Labor ...................................................................19

6. Why Has Economic Convergence Across the Länder Stopped? ...............................31

Figures

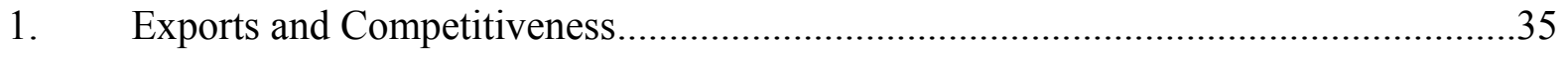

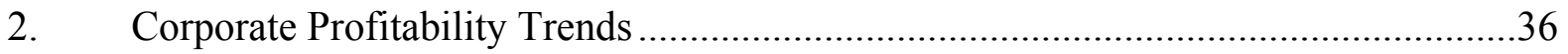

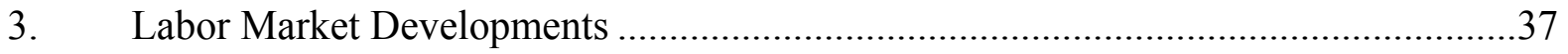

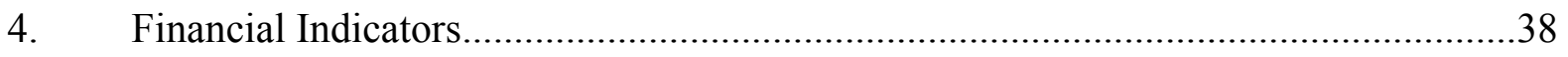

5. Corporate Spreads, Money Market Rates, and Lending Standards ...........................39

6. Sentiment, Orders, and Production .........................................................................40

7. Comparison of Business Cycles, 1990-2007 .......................................................41

8. Labor Productivity Growth, Contributions From TFP, and Capital Deepening ..........42

9. Selected Countries: Patents Developments.........................................................43

10. Labor Market and Migration Trends ................................................................44

11. Selected Countries: Traditional Bank Financing ................................................45

12. Selected Countries: Capital Markets in Comparative Perspective .............................46

13. Selected Countries: Equity Market Efficiency ...............................................47 


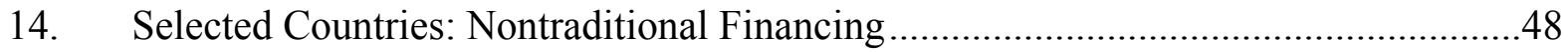

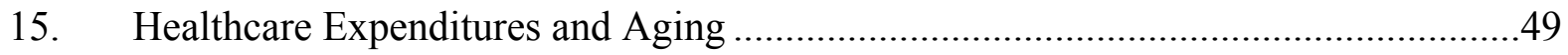

Tables

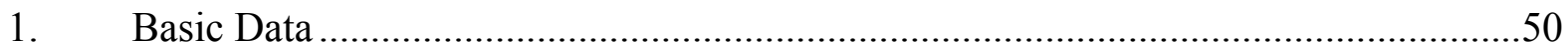

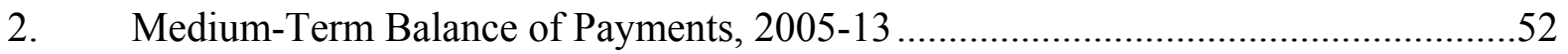

3. Core Set of Financial Indicators for Banks, 1998-2006 ..........................................53

4. Encouraged and Other Financial Soundness Indicators, 1998-2006 ...........................54

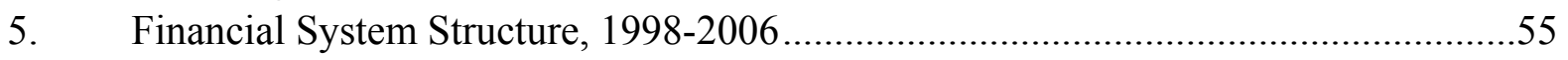

6. General Government Finances, 2002-12 ………...............................................56

Appendices

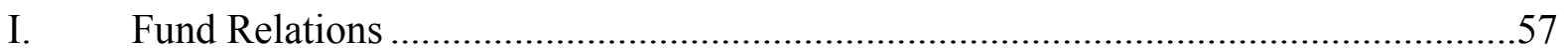

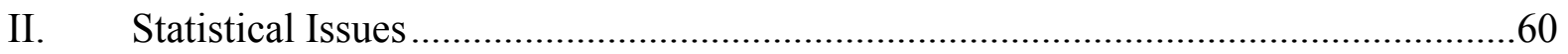




\section{The ConteXT}

1. The economy has made major strides, helped by wide-ranging reforms. From the doldrums of 2001-03, strong external competitiveness generated a robust recovery, with beneficial spillover effects for Europe. With strong performance in 2006 and much of 2007, a welcome decline in unemployment is ongoing. These developments have been aided by extensive reforms, including in labor and capital markets. Determined fiscal

consolidation has enhanced policy credibility.

\begin{tabular}{lr}
\multicolumn{2}{c}{ Reform Initiatives and Implementation } \\
\hline Sector & Date \\
\hline Labor market & $2003-04$ \\
$\quad$ Administration and program reform Hartz (I-III) & $2005-06$ \\
Unemployment benefit reform(Hart IV) & $2007-08$ \\
Fiscal & 2004,2007 \\
$\quad$ Tax reform (VAT, CIT) & 2006 \\
Pension reforms 1/ & $2004,2007-09$ \\
$\quad$ Fiscal federalism reform (Phase I) & 2005 \\
$\quad$ Health care reform1/ 2/ & 2002 \\
Structural & 2007 \\
$\quad$ Network industry regulation & \\
Banking sector and capital markets & \\
$\quad$ Supervision reform (Bafin establishment) & 2002,2007 \\
$\quad$ REITS legislation & \\
$\quad$ German Code of Corporate Governance &
\end{tabular}

\section{Germany, however, faces key challenges, with a growing risk that these may interact in insidious ways:}

- The rescue of two German banks in the summer of 2007 raised concerns that the problems may be more widespread. With the international subprime fallout still ongoing, the drip of bad news has continued, generating appreciable risks to economic confidence and short-term prospects.

- These developments come at a time when - despite progress - a sustainable increase in potential growth has not yet been secured and German consumers remain ambivalent about future prospects.

- $\quad$ The hard-won competitiveness gains could be eroded without an impetus to productivity growth. Wages remain high for unskilled labor and low returns to human capital contribute to skilled emigration. Aging costs remain a threat to fiscal sustainability.

- $\quad$ The prospects for further reforms have dimmed with no major policy proposals in the pipeline. And recent labor market measures motivated by "fairness" create distortions and incentives inimical to employment and output growth.

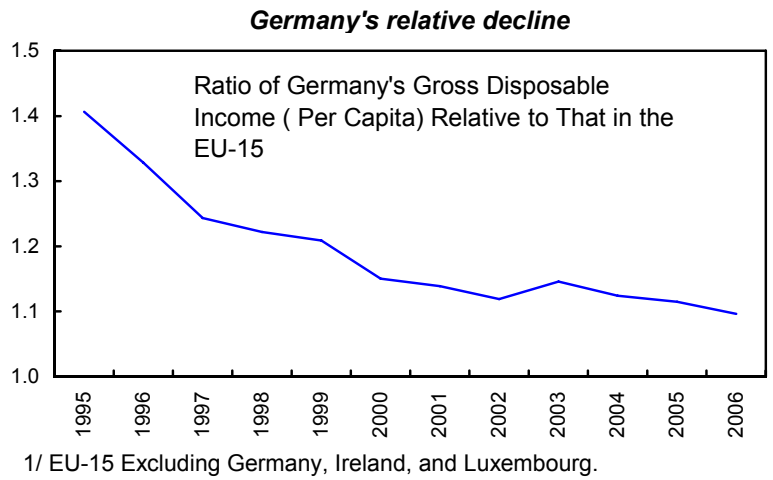

3. Pressing ahead with reforms, therefore, remains crucial. The immediate priorities are preserving the integrity of the financial system and maintaining economic confidence. However, significant medium-term challenges remain (Box 1). These include further efforts to foster employment and growth, while confronting the pressures from global movement of labor and capital and also achieving regional balance within Germany. This, in turn, will 
require a continued reorientation of traditional, corporatist institutions - wage bargaining, relationship banking, insider-dominated corporate governance, and federal decision making. Preserving solidarity through shared gains, while accommodating the forces of global competition, is the overarching challenge.

\section{Box 1. Past Fund Policy Recommendations and Implementation}

Following much progress in implementing policies recommended by Directors, the reform momentum has slowed noticeably:

Foundations for employment and growth. The authorities regard rationalization of programs under Hartz IV as a priority, but implementation has lagged. There has also been no progress in reforming employment protection legislation. Despite Directors' urging to refrain from introducing minimum wages, a sectoral minimum wage has been instituted for postal workers.. The proposed extension of unemployment benefits for elderly workers also goes against the Directors' advice to increase the incentives for work. Initiatives for cutting red tape are, however, proceeding through the Normenkontrollrat.

Financial sector efficiency. Directors have underscored the importance of an efficient financial sector. To date, bank restructuring initiatives have been limited, as has been the role of private capital - which Directors have seen as vital. The authorities are exploring rationalization of banking supervision. Following the introduction of real estate investment trusts, a push on capital market development is not imminent; indeed, risks are associated with some proposed measures.

Fiscal consolidation and reforms. Directors have welcomed the authorities' strong expenditurebased measures for fiscal consolidation and the substantial progress in reducing long-term aging costs. But they have cautioned that fiscal sustainability will not be assured even if the structural deficit were to be eliminated by 2010. Accordingly, they have encouraged the authorities to pursue a broad-based approach, encompassing both fiscal adjustment and growth-enhancing reforms.

\section{RECENT ECONOMIC DEVELOPMENTS}

4. The upswing maintained traction in 2007. From the cyclical trough in 2004, GDP growth accelerated to 2.9 percent in 2006, the highest rate since unification (except in 2000). Output grew by 2.5 percent in 2007 , with an unexpectedly strong third-quarter performance, despite the onset of the financial turbulence. Output is now close to potential. Growth in 2007 was not dented by high oil prices, fiscal consolidation, or first-quarter contraction in consumption (following purchases in 2006 in advance of the VAT hike). Reductions in social

\begin{tabular}{lcc}
\multicolumn{3}{c}{ Comparison of Real GDP Projections (percent) } \\
\hline \multicolumn{2}{c}{2006} & 2007 \\
\hline IMF staff & & \\
Staff report December 2006 & 2.3 & 1.4 \\
WEO April 2007 & 2.7 & 1.8 \\
WEO July 2007 & 2.8 & 2.6 \\
WEO September 2007 & 2.9 & 2.4 \\
Authorities October 2007 & 2.9 & 2.4 \\
Consensus October 2007 & 2.9 & 2.6 \\
\hline
\end{tabular}


contributions and a boost in investment driven by the impending elimination of a depreciation allowance in 2008 helped temper the contractionary effects.

5. The external competitive position remained strong. Price competitiveness (helped by decade-long wage moderation) has permitted sustained export growth (Figure 1). Export earnings and their stimulative effect on investment have contributed to growing corporate profitability (Figure 2).

\section{Employment-especially full-time} employment-started picking up in mid-2006.

Protracted labor shedding and wage moderation were instigated by the pressures to remain competitive. With wage moderation legitimized and reinforced by the

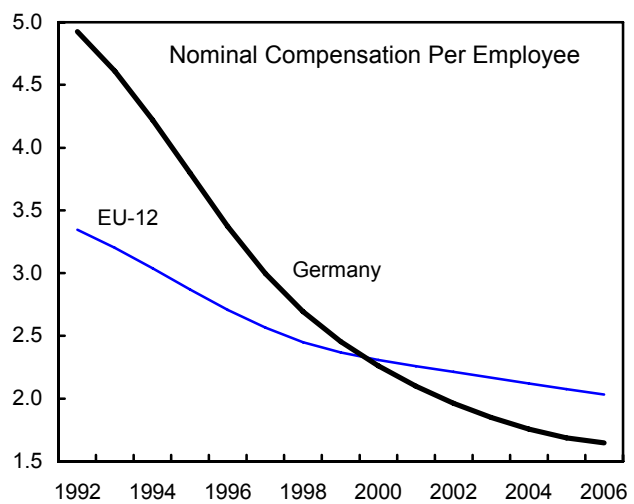
Hartz IV reforms, short-term unemployment has fallen. Indeed, the labor market has shown signs of tightening with increasing vacancy rates and a pick up in wage growth (Figure 3). Collective wage agreements imply an average gross wage increase of about 2 percent in 2008.

7. A balanced budget is the result of sustained effort. From 4 percent of GDP at the trough of the cycle in 2004, the general government deficit reached balance in 2007. Although this adjustment coincided with the upswing, substantial policy effort contributed to a structural adjustment of about three percent of GDP between 2003 and 2007. Much of this adjustment reflected cuts in discretionary, aging, and welfare expenditures. In 2006, the structural balance improved by more than one percentage point, meeting the target set under the excessive deficit procedure ahead of schedule. The adjustment continued in 2007 with the VAT hike, reduction in the deductibility of interest income, expenditure restraint, and increase in healthcare premiums.
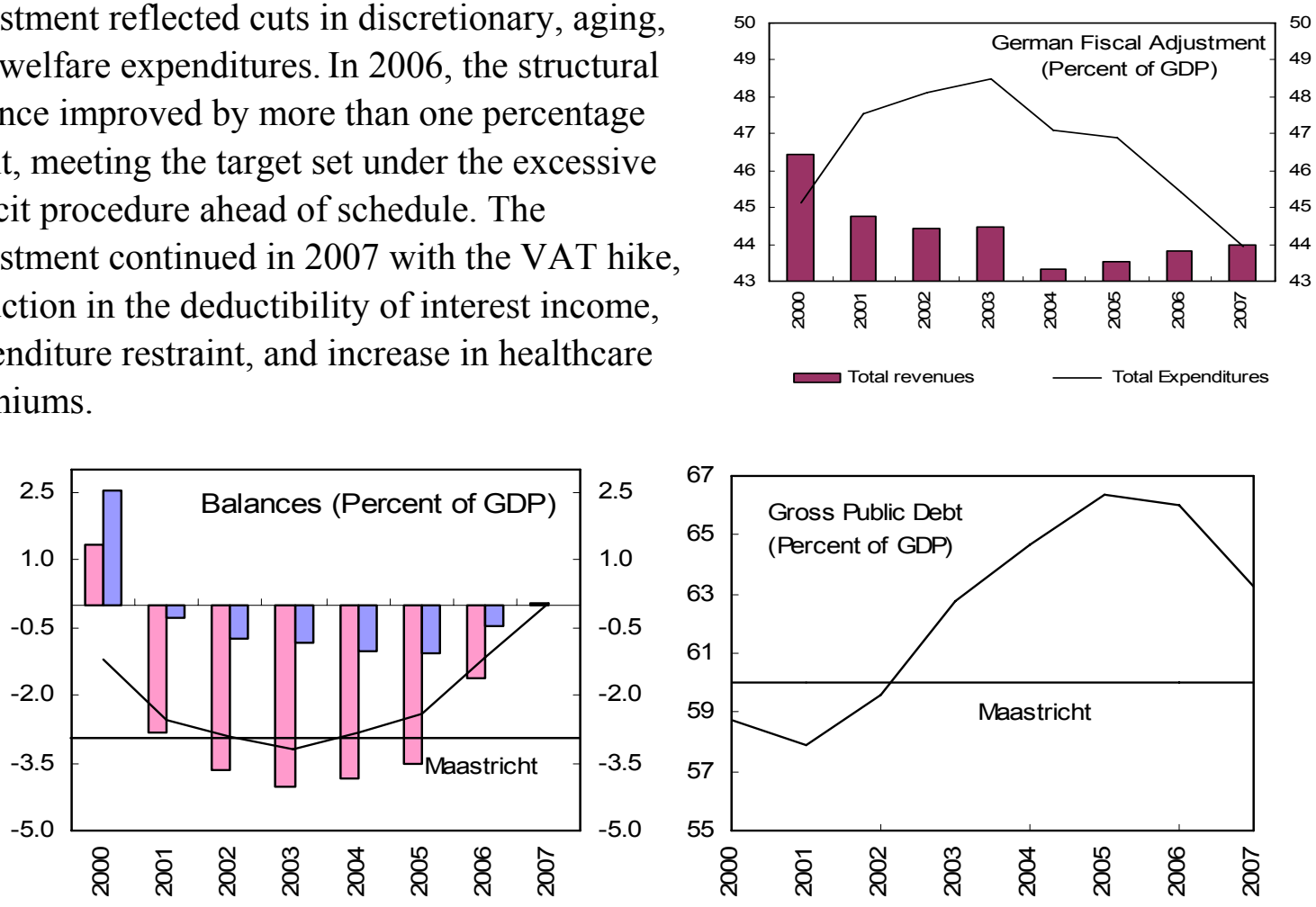

Overall $\longleftarrow$ Cyclical and one off — Structural

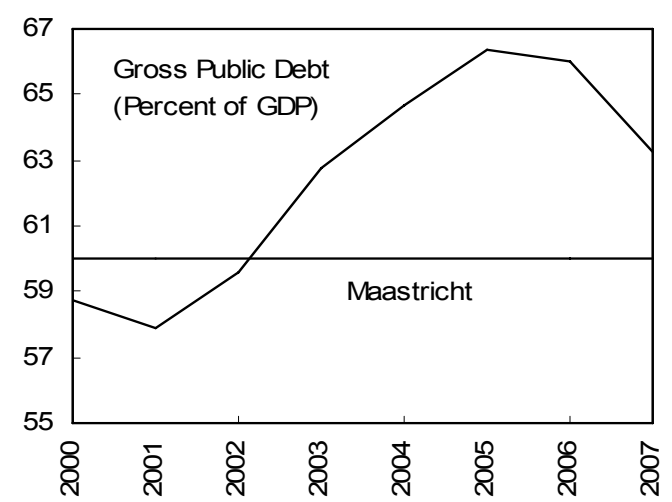


8. Inflation has remained moderate despite domestic and global pressures. In the first 11 months of 2007, headline inflation was 2.2 percent at an annualized rate, and core inflation was 2.0 percent. The sizable VAT hike in January 2007 (from 16 to 19 percentage points) had a relatively benign effect, pushing up core inflation smoothly by 0.7 percentage point rather than the expected 1.1 percentage points (Box 2). Renewed energy price inflation and a jump in food prices raised year-on-year headline inflation to 3.3 percent in November but core inflation was 2.4

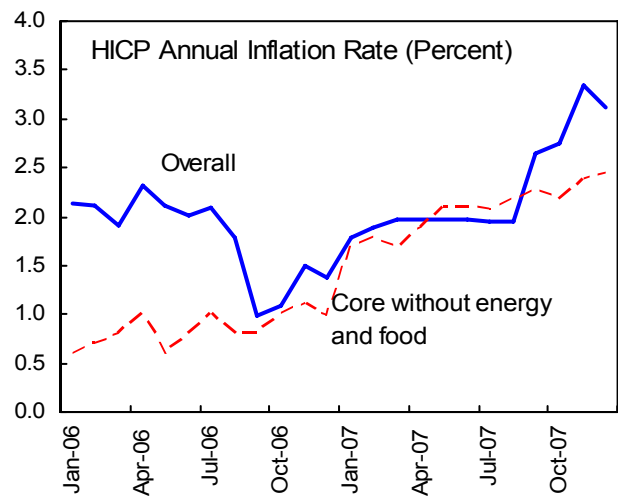
percent.

\section{International financial turbulence hit Germany with force, casting a cloud on} the sustainability of the gains achieved. Last summer, IKB (a private bank, but with a onethird ownership by the governmentowned KfW) and Sachsen Landesbank (a state-owned bank) had to be rescued after they were unable to meet their liquidity commitments to their off-balance-sheet "conduits." German banks were placed under close market scrutiny, with credit default spreads rising sharply (text figure and Figures 4 and 5). Thereafter, concerns about the German financial sector softened, especially relative to the

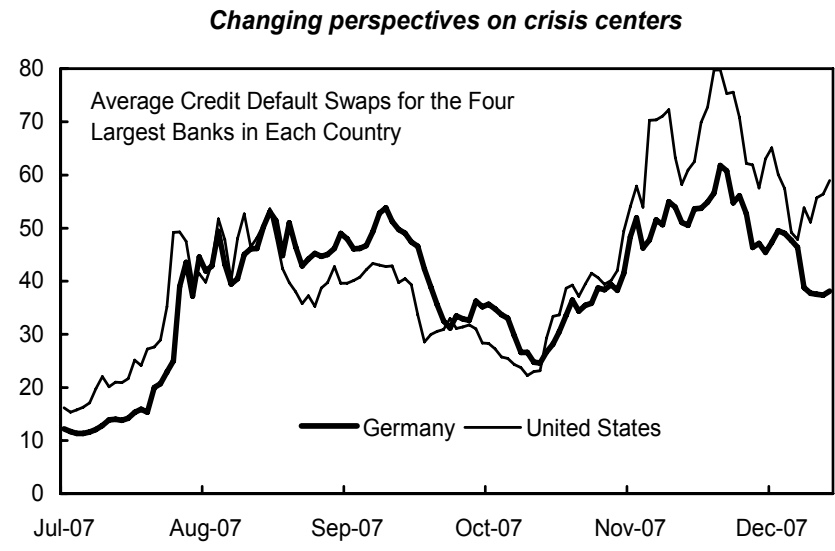
magnitude of the problems revealed in the United States. In November, the German share of main and longer-term ECB refinancing operations fell below 50 percent from about 55 percent in the first seven months of 2007. However, revelations of further write-downs have continued and German banks - notably West LB, another state-owned bank-remain under watch (text table below). Moreover, many banks have not released year-end statements and further negative surprises seem likely. 
Exposure of Select European Banks to Conduits and Special Investment Vehicles (SIVs)

\begin{tabular}{|c|c|c|c|c|c|}
\hline & \multirow[t]{2}{*}{ Ownership 1/ } & \multicolumn{2}{|c|}{$\begin{array}{l}\text { Conduit- and SIV-Financed Assets } \\
\text { (Percent) }\end{array}$} & \multirow{2}{*}{$\begin{array}{c}\text { Liquidity Facilities 2/ } \\
\text { (US\$; billions) }\end{array}$} & \multirow[t]{2}{*}{$\begin{array}{l}\text { Liquidity Facilities } 3 / \\
\text { (In percent of funding) }\end{array}$} \\
\hline & & Over Equity & Over Assets & & \\
\hline \multicolumn{6}{|l|}{ Germany: } \\
\hline Sachsen-Finanzgruppe & Public & 1,126 & 30.3 & 24.0 & 31.6 \\
\hline West LB & Public & 542 & 12.7 & 21.1 & 5.7 \\
\hline IKB (until 29 July 2007 , i.e., before bailout) & Private & 494 & 20.5 & 19.5 & 28.8 \\
\hline Dresdner Bank (mitigated by integration into Allianz group) & Private & 364 & 9.9 & 39.8 & 6.2 \\
\hline Landesbank Berlin (mitigated by integration into S-Group) & Public & 179 & 2.2 & 2.4 & 1.3 \\
\hline BayernLB (mitigated by integration into S-Verbund Bayern) & Public & 170 & 5.1 & 27.7 & 6.6 \\
\hline HSH Nordbank & Public & 126 & 4.0 & 7.0 & 2.9 \\
\hline Deutsche Bank & Private & 114 & 3.3 & 69.7 & 4.8 \\
\hline HVB (mitigated by integration into UCl group) & Private & 105 & 6.6 & $\ldots$ & $\ldots$ \\
\hline NORD LB & Public & 89 & 2.9 & 6.9 & 2.8 \\
\hline Commerzbank & Private & 85 & 2.2 & 18.7 & 2.4 \\
\hline Helaba (mitigated by integration into S-Verbund $\mathrm{HT}$ ) & Public & 68 & 1.1 & 4.3 & 2.0 \\
\hline DZ-BANK (mitigated by integration into Cooperative Network) & Private & 61 & 1.3 & 9.9 & 1.8 \\
\hline LBBW & Public & 59 & 1.7 & 8.7 & 1.6 \\
\hline $\mathrm{KfW}$ (mitigated by unlimited sovereign guarantee) & Public & 58 & 2.6 & $\ldots$ & $\ldots$ \\
\hline \multicolumn{6}{|l|}{ Europe: } \\
\hline ABN Amro & Private & $\ldots$ & $\ldots$ & 107.5 & 10.7 \\
\hline Lloyds Bank Group & Private & $\ldots$ & $\ldots$ & 39.1 & 7.2 \\
\hline Societé Genérale & Private & $\cdots$ & $\cdots$ & 42.0 & 6.2 \\
\hline Fortis & Private & $\ldots$ & $\ldots$ & 39.9 & 5.6 \\
\hline Rabo Bank & Private & $\cdots$ & $\cdots$ & 32.2 & 5.2 \\
\hline Barclays & Private & $\ldots$ & $\ldots$ & 43.5 & 4.5 \\
\hline RBS Group & Private & $\ldots$ & $\ldots$ & 47.9 & 3.9 \\
\hline ING & Private & $\begin{array}{l}\cdots \\
\ldots\end{array}$ & $\begin{array}{l}\cdots \\
\ldots\end{array}$ & 34.2 & 3.6 \\
\hline CSFB & Private & $\ldots$ & $\ldots$ & 14.2 & 3.1 \\
\hline HSBC Holdings & Private & $\cdots$ & $\cdots$ & 33.7 & 2.8 \\
\hline BNP & Private & $\ldots$ & $\ldots$ & 20.0 & 2.4 \\
\hline Santander & Private & $\ldots$ & $\cdots$ & 7.1 & 1.1 \\
\hline Intesa San Paolo & Private & $\ldots$ & $\cdots$ & 2.7 & 0.9 \\
\hline
\end{tabular}

Source: Fitch Ratings.

1/ Majority ownership.

2/ Maximum commitments.

3/ Funding defined as deposits plus senior and subordinated debt as of end-December 2006, or end-March 2007. 


\section{Box 2. The Smoothing of the VAT Increase}

The smaller-than-anticipated inflation spike following the January 1, 2007 VAT hike was the consequence of a long announcement period-13 months. Consumers made advance purchases, and retailers raised prices prior to the VAT-hike implementation. An econometric analysis of sectoral inflation trends shows that 0.3 percentage point of the increase in core inflation in 2006 can be attributed to the anticipated VAT hike. ${ }^{1}$ Advance price increases were higher for durable goods and commodities with less competitive markets.
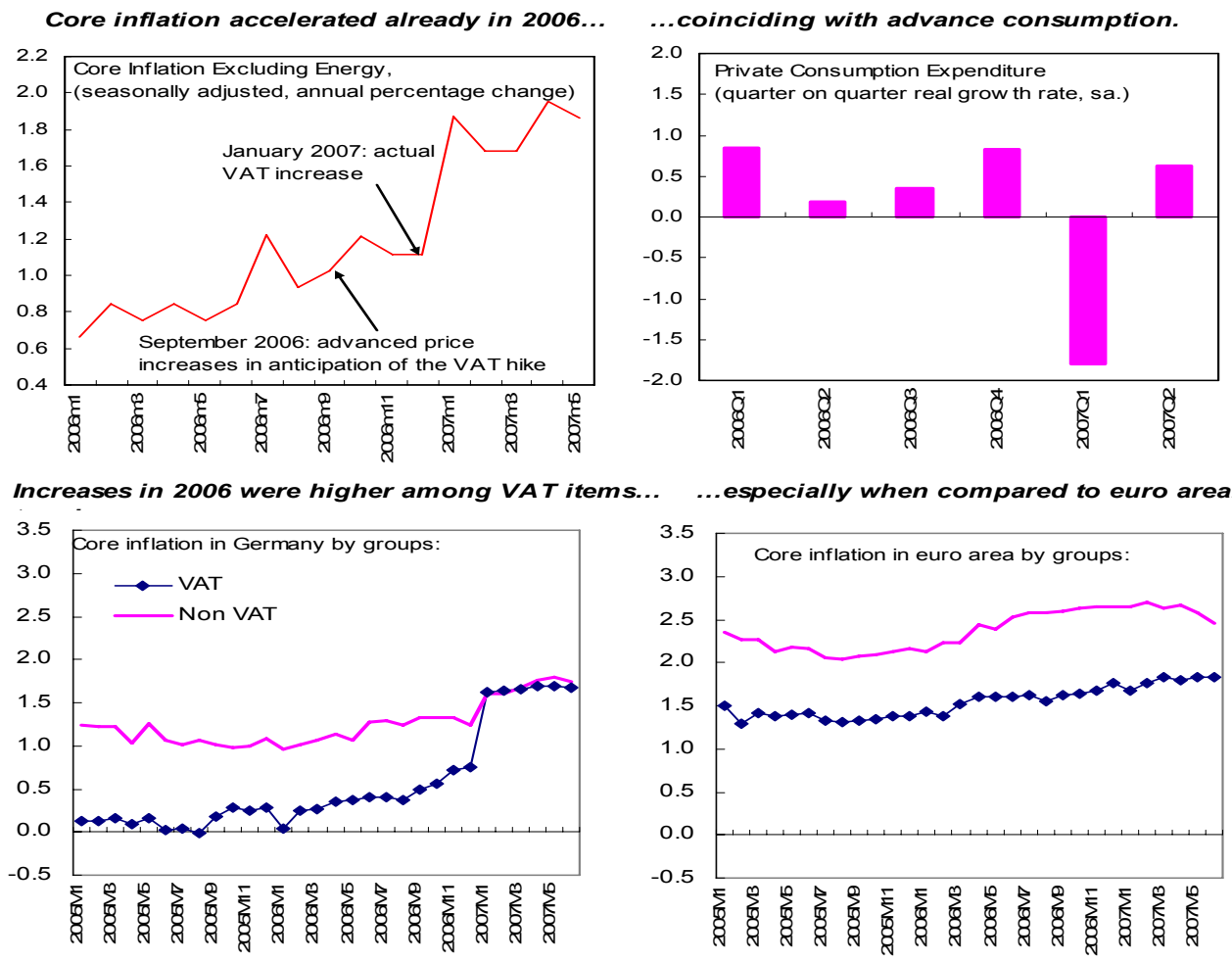

${ }^{1}$ See Selected Issues, Chapter I. The model controls for common price shocks within the euro area, seasonal factors, and onetime effects. 


\section{OUTLOOK AND RISKS}

\section{A. Short-Term Outlook}

\section{In the currently evolving situation growth is projected to slow with the} weakening global cycle. In the first half of

2007, forecasters presumed that the German and U.S. economies were "decoupling" (text figure). However, the fourth-quarter signals presaging a slowing German momentum (Figure 6) are now tied to weaker U.S. growth (Box 3). Both sides agreed that the weaker U.S. economy - through slower world trade - would be the primary factor pulling down German GDP growth, given its strong external dependence. Growth would be more modestly dampened by the stronger eurocushioned by the reliance on imported inputs. On the positive side, employment gains are

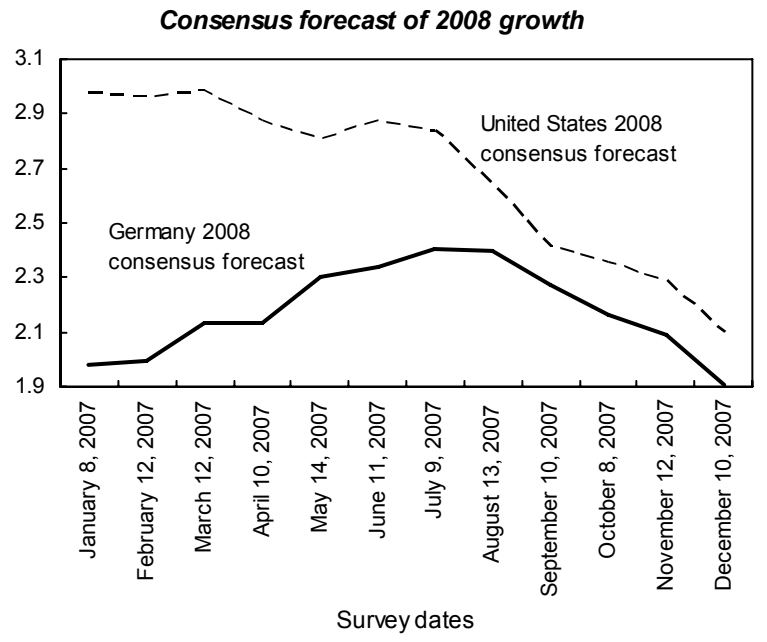
projected to fuel the beginning of a consumption recovery, holding GDP growth up at 1.7 percent in 2008 (text table). ${ }^{1}$

Comparison of the 2008 Forecasts

(Percent Change)

\begin{tabular}{lcc}
\hline & $\begin{array}{c}\text { Real Gross } \\
\text { Domestic product }\end{array}$ & $\begin{array}{c}\text { Real Private } \\
\text { Consumption }\end{array}$ \\
\hline $\begin{array}{l}\text { Corrected institute projections (Dec. 13) } \\
\text { IfW - Kiel Institute }\end{array}$ & 1.9 & $\ldots$ \\
IFO - Munich Institute & 1.8 & 1.5 \\
IMF (internal: WEO, Dec 13, 2007) & 1.8 & 1.6 \\
IMF (Interim WEO update, January 2008) & 1.7 & 1.4 \\
Bundesbank (Dec. 18, 2007) & 1.9 & 1.1 \\
Federal Government (Jan. 23, 2008) & 1.7 & 1.4 \\
IMF (Jan. 25, 2008) & 1.7 & \\
\hline
\end{tabular}

\footnotetext{
${ }^{1}$ Subject to ongoing WEO revision.
} 


\section{Box 3. Germany's Growth Linkages ${ }^{1}$}

U.S. and European growth impulses have a significant bearing on German growth. A vector autoregression (VAR) of real GDP growth in the U.S., Japan, Germany, the rest of the euro area, and new EU members finds that changes in U.S. GDP growth affect activity in Europe but not vice versa. ${ }^{2}$ Growth impulses from other euro area countries translate almost one for one into higher growth in Germany and the rest of Europe.

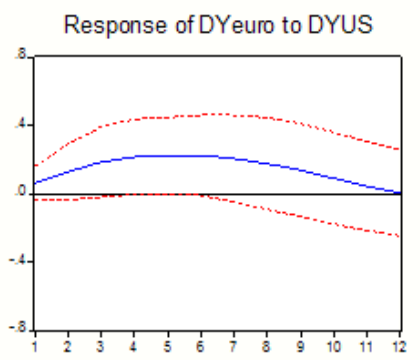

Response of DYGer to DYUS
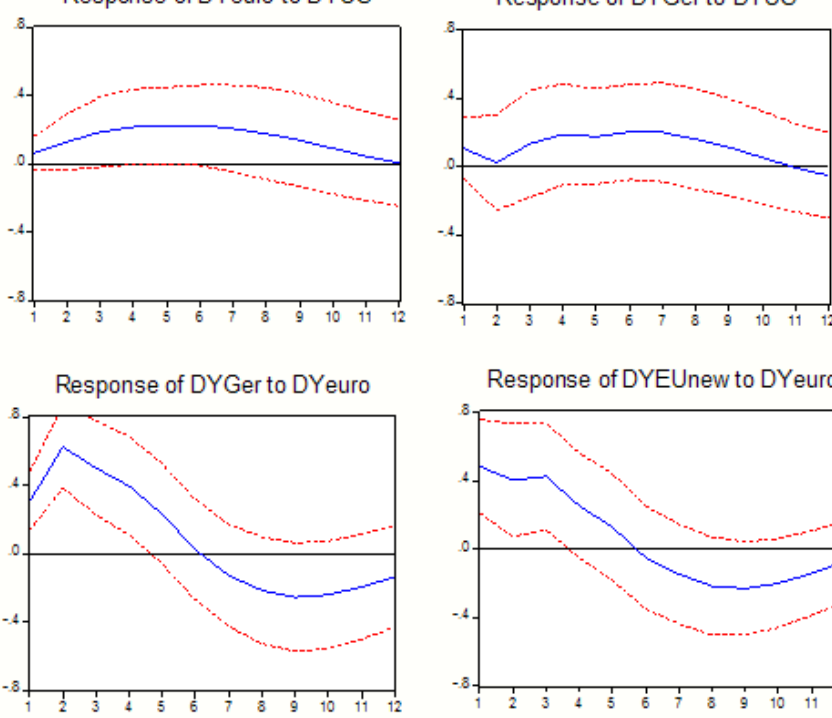

Response of DYEUnew to DYeuro

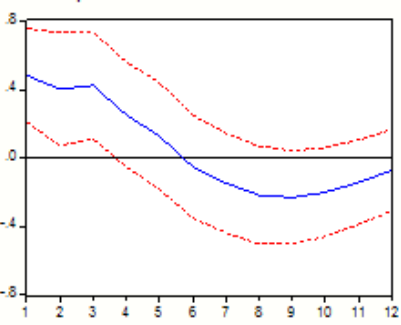

\section{Growth spillovers from}

Germany were limited in the past but are more prominent now. Estimates for the most recent period (1998-2007) indicate that a $1 / 2$ percent increase of German GDP raises growth in the rest of the euro area by

$1 / 4$ percent and by about $1 / 2$ percent in the new EU member countries after three quarters. These effects point to increasing economic integration especially with the new member states (e.g., offshoring).
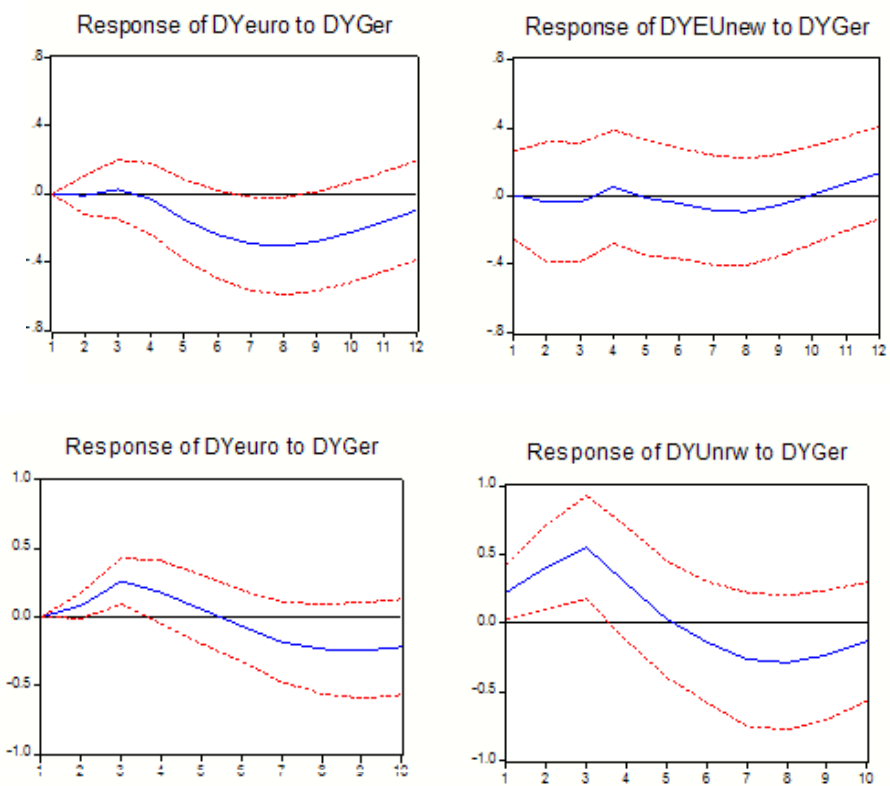
Source: Response of GDP growth (DY) to one S.D. Innovation based on Cholesky decomposition. The top six panels refer the period 1993q1-2007q2, the bottom two panels refer to 1998q1-2007q2.

${ }^{1}$ See Selected Issues, Chapter 2.

${ }^{2}$ For similar results see WEO April 2007, Chapter 4. 

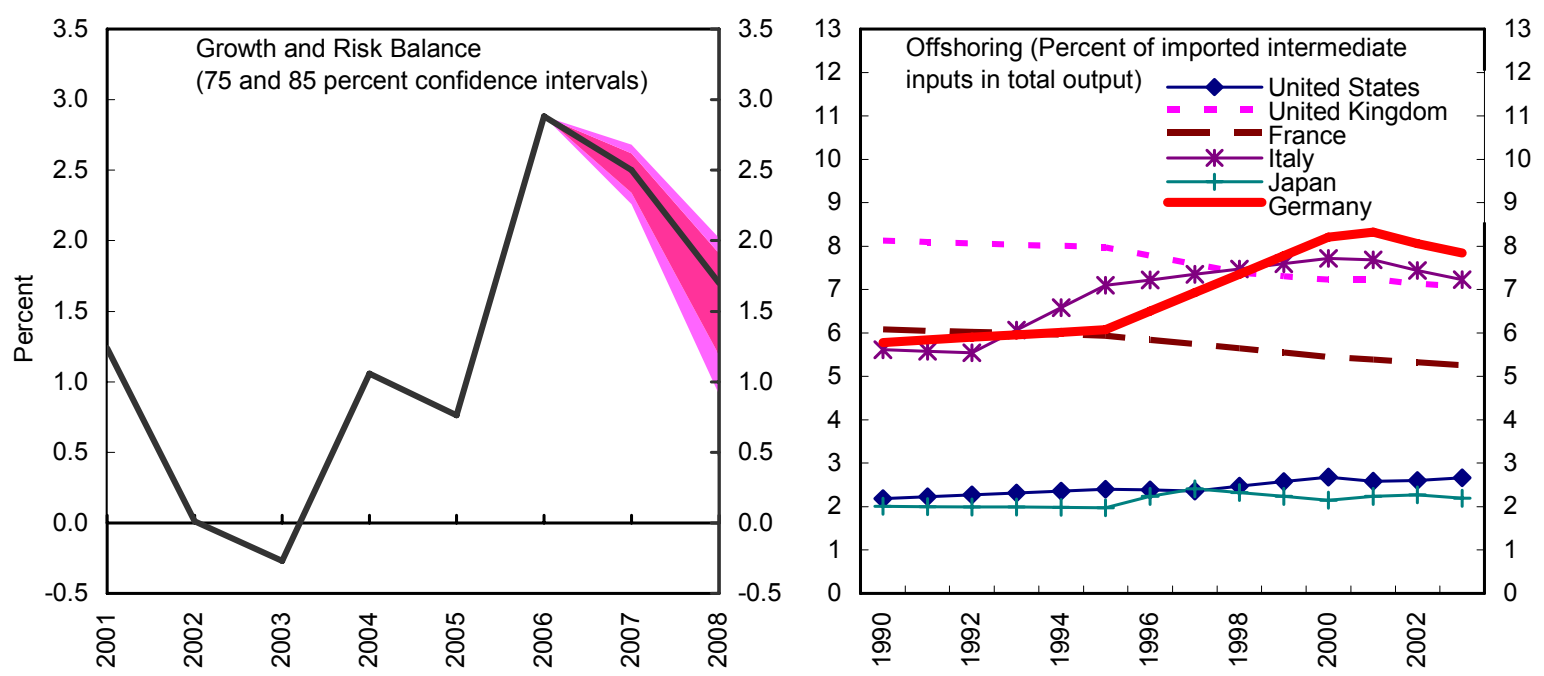

11. However, the uncertainties have increased considerably and risks are firmly on

the downside. A sharper-than-anticipated slowdown in the United States would have a potentially sizeable impact on German growth, all the more so if it undermined confidence. Strong external production linkages imply significant spillovers from Germany to the rest of Europe, especially emerging Europe (text figure). Euro appreciation associated with a disruptive unwinding of global imbalances and, hence, sharply lower world growth would also amplify the consequences of a strong euro (Box 4). Higher-than-expected oil prices would act directly and, by dampening sentiments, weaken the consumption recovery; the oil-price effect, however, would be mitigated if the euro also appreciates. 


\section{Box 4. Growth Consequences of the Euro Appreciation}

Real exchange rate movements have limited growth effects during periods of robust global growth. The current real appreciation of 3.9 percent (between January 2006 and October 2007) is moderate compared with past fluctuations. Staff econometric analysis suggests that this adjustment could dampen annual growth by less than 0.2 percentage point.

The negative effects can, however, increase significantly in a global downturn. Staff estimates show that a real exchange rate appreciation in Germany has up to twice the direct effect when the global output is well below potential. Although such events have been rare, the risks to global growth raise the possibility of a more significant negative growth

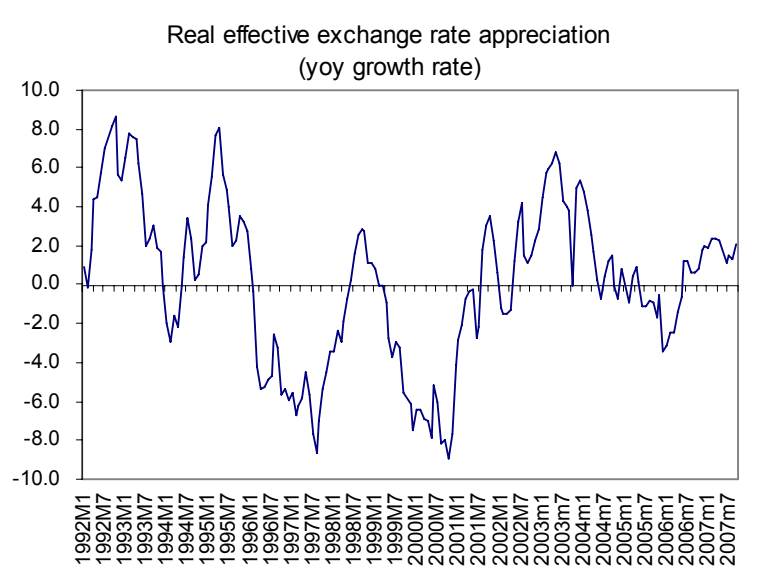
effect of a euro appreciation.

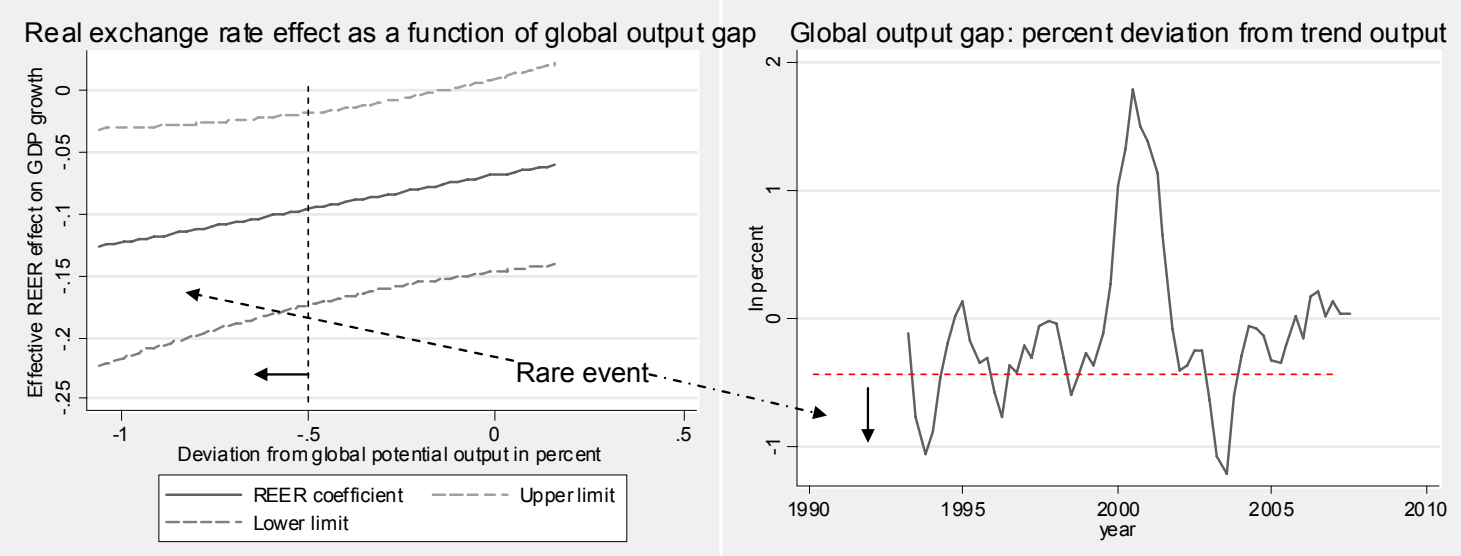

Source: Staff estimates. Global output gap measured as percent deviation from HP filtered trend.

${ }^{1}$ Measured in CPI terms based on the IMF methodology: http://www.imfstatistics.org/imf/IFSExcha.htm.

12. The authorities are acutely conscious that the greatest uncertainty arises from the unfolding international financial developments. In this context, they have taken valuable steps to assess the exposures of German banks. Consistent with their preliminary conclusion that the exposures are limited and have not impaired capital positions, credit flows thus far have remained relatively unaffected. Banks came into the crisis well capitalized and with cyclically strong profits. Moreover, the reliance of German businesses and households on financial credit is relatively modest and apparently declining (text figure). However, the authorities recognize that the turmoil has proved to be a moving target and, hence, the findings from bank examinations and stress tests can become quickly outdated. Recent indications are that lending standards have tightened, although less than elsewhere in the euro area. The continuing turbulence could further impact asset valuations and capital levels - with adverse and cascading consequences for credit availability and growth. 


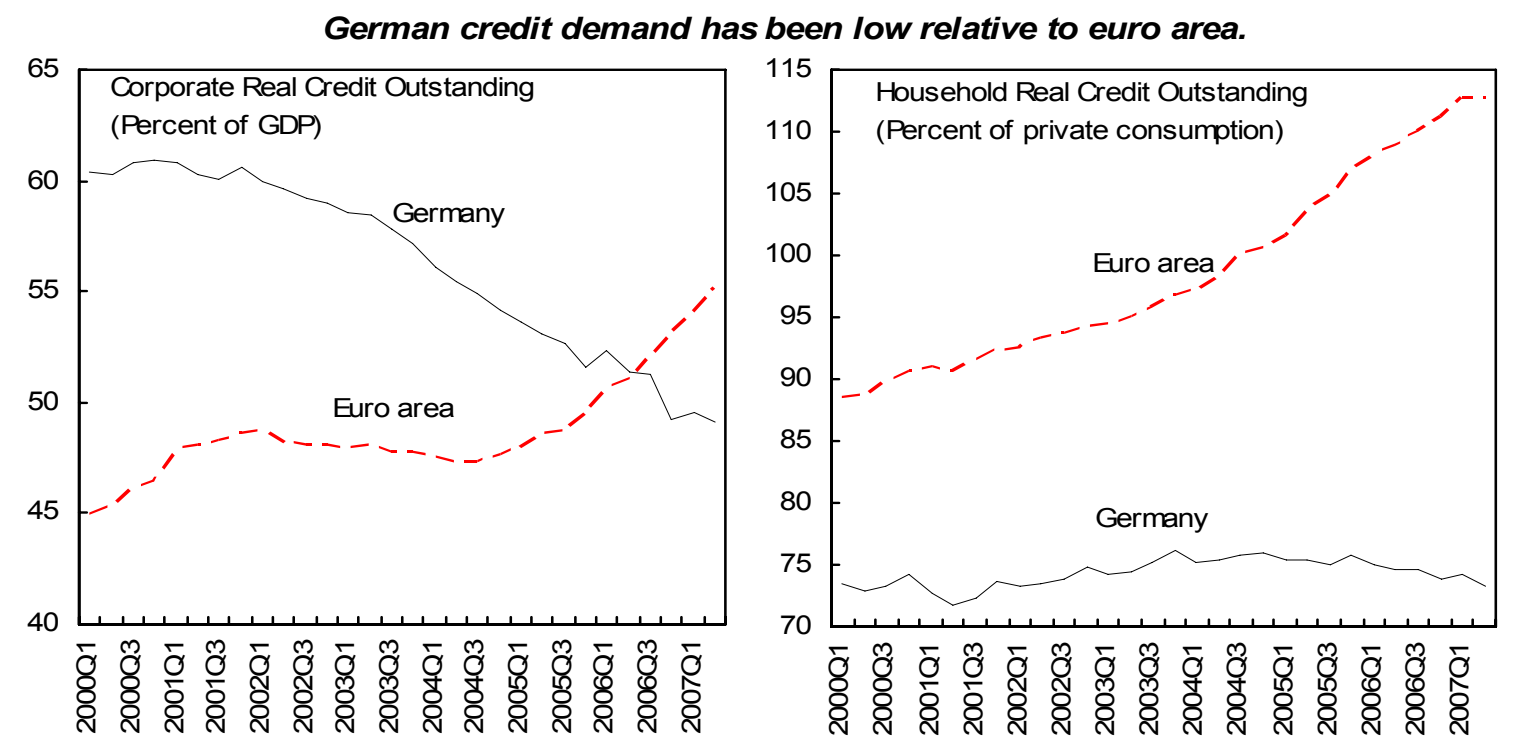

13. Inflation should slow somewhat, to $\mathbf{2 . 1}$ percent in $\mathbf{2 0 0 8}$, but the risks are on the upside. The price increase following the 2007 VAT hike will exert a dampening base effect. Oil and food price inflation are projected to add an inflationary bias, though the effects are expected to ease slowly. Higher outcomes from the new wage bargaining create risks of second-round spillovers, which, however, are likely to be mitigated by slower growth.

\section{B. Competitiveness}

14. Germany's competitiveness is adequate, with some evidence of a modest undervaluation. This conclusion, which the authorities broadly agreed with, is based on several considerations:

- The current account surplus is largely structural and is expected to contract in the medium term. Despite strong investment trends, the current account surplus widened to an estimated 5.6 percent of GDP in 2007 (Tables 1 and 2). The surplus was, however, boosted by temporary factors, in particular, the increase in the VAT rate that increased private and public savings. Stripping out these and other temporary factors from long-term trends, staff's estimate of the current underlying surplus is about $4 \frac{1}{4}$ percent of GDP.

- For Germany, the CGER exercise estimates a medium-term current account norm (reflecting long-term trends in a multilateral setting) of 3.3 percent of GDP. This norm is higher than that of other major European countries, reflecting mainly savings for old age and European financial integration that generates capital flows from Germany to the less advanced European economies. The authorities' estimates show that about half of Germany's current account surplus derives from within the euro area, with a surplus on the trade account, reflecting competitive strength in manufactured goods, and a deficit on the services account. 
Comparison of the Real Exchange Rate Assessment and Current Account (CA) Positions and Current Account Norm Contributions for the Three Largest Euro Area Countries 1/

\begin{tabular}{|c|c|c|c|c|c|c|c|c|c|c|c|c|}
\hline & \multicolumn{3}{|c|}{ CGER Assessment } & \multicolumn{2}{|c|}{2007 CA/GDP } & \multirow{2}{*}{$\begin{array}{l}\text { CA/GDP } \\
\text { norm }\end{array}$} & \multicolumn{6}{|c|}{ CA Norm Contributions } \\
\hline & MB 2/ & ERER 3/ & ES 4/ & Actual & Underlying 5/ & & CA lag & $\begin{array}{l}\text { Dependency } \\
\text { ratio }\end{array}$ & $\begin{array}{l}\text { Population } \\
\text { growth }\end{array}$ & $\begin{array}{c}\text { Per } \\
\text { capita } \\
\text { growth }\end{array}$ & $\begin{array}{l}\text { Relative } \\
\text { income }\end{array}$ & Other 6/ \\
\hline Germany & -2.0 & 3.0 & -10.0 & 5.6 & 4.2 & 3.3 & 1.3 & 0.8 & 0.5 & 0.0 & -0.5 & 1.2 \\
\hline France & -2.0 & 2.0 & 6.0 & -2.0 & -1.6 & -1.8 & 0.0 & -0.5 & 0.0 & 0.0 & -0.5 & -0.8 \\
\hline Italy & 5.0 & 6.0 & 5.0 & -2.3 & -1.9 & -0.5 & -0.5 & 0.9 & 0.5 & 0.0 & -0.6 & -0.8 \\
\hline
\end{tabular}

1/ CGER (Consultative Group on Exchange Rate Issues). Values between -10 and +10 means the real exchange rate (RER) is close to balance. International Monetary Fund, 2006, Methodology for CGER Exchange Rate Assessments (available at www.imf.org).

2/ Macroeconomic balance approach.

3/ Equilibrium real exchange rate approach.

4/ External sustainability approach.

5/ The underlying CA/GDP balance is calculated as ratio of Hodrick Prescott filters of current account balances and for nominal GDP for 1970 until 2013.

6/ Oil balance to GDP, and dummies for the EMU creation and if the country is a financial center, etc.

- According to CGER estimates, the real exchange rate is close to equilibrium.

These estimates show that the valuation of the real effective exchange rate (REER) to range from 3 percent overvaluation (equilibrium real exchange rate approach) to a 10 percent undervaluation relative to equilibrium (external sustainability approach, see text table), with large standard errors. The mid-point of the range - suggesting a 3-5 percent undervaluation - is normally considered a reasonable benchmark and also coincides with the estimate from the macroeconomic balance approach.

\section{- The implication is that the depreciation during the late 1990s and early this} decade has mainly corrected the overvaluation of the mid-1990s. As that overvaluation declined, Germany gained market shares; these shares have now begun to stabilize. The authorities emphasized the uncertainties in measuring equilibrium exchange rates. Their favored approach - treating the average over the past three decades as the "equilibrium"-also finds a small undervaluation. 


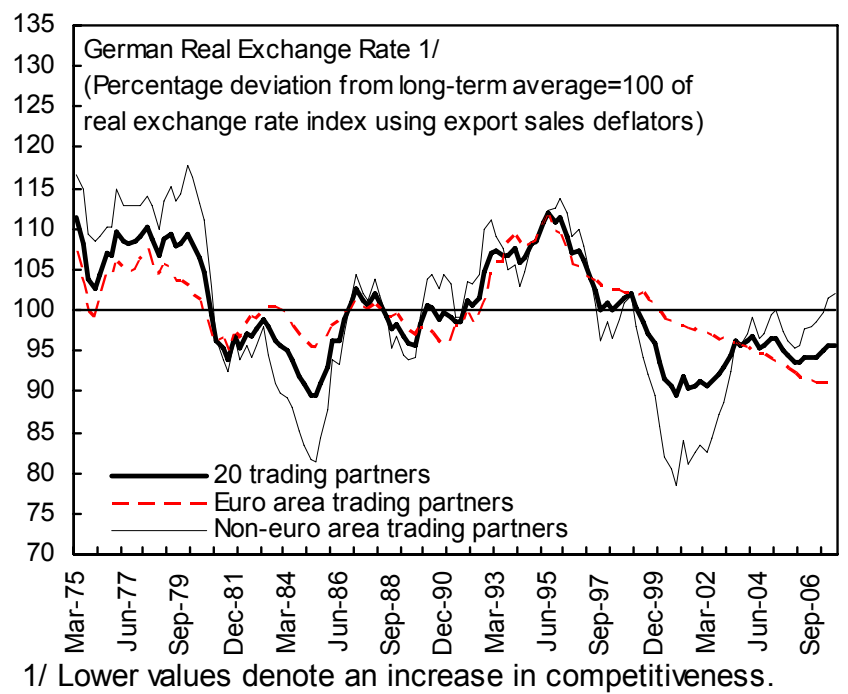

\section{Medium-Term Outlook}

15. Growth is projected to slow to the potential rate of $1 \frac{3}{4}$ percent annually, unless measures are taken to step up total factor productivity growth. The strength of the current upswing has not clearly surpassed previous ones (although it is notable in its unusual composition - buoyant investment and lagging consumption) (Figure 7). The output gap, created following the poor performance earlier in the decade, is just about closed. Looking ahead, productivity growth - crucial to maintaining the growth momentum - is difficult to predict, but recent trends are not comforting. Labor productivity rose by about $2 \frac{1}{2}$ percent in 2006 from a substantial fall earlier in the cycle (text figure), but increased by less than 1 percent in 2007. Moreover, productivity has been sustained mainly in the manufacturing sector, which accounts for a quarter of value added (Figure 8). The much larger services sector - with two-thirds of the value added - has shown little improvement, this being especially true for real estate and financial services. German firms are highly innovative, measured, for example, by the production of patents (Figure 9). However, the translation of the innovation into productivity increases has

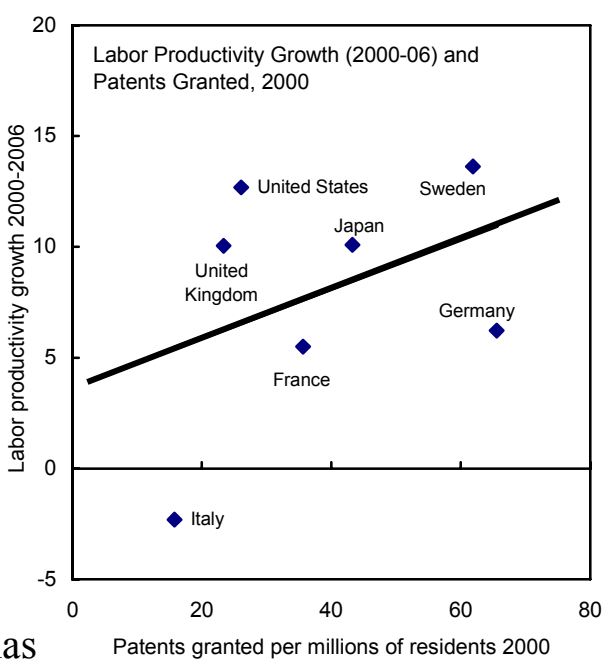
been weak (text figure). 

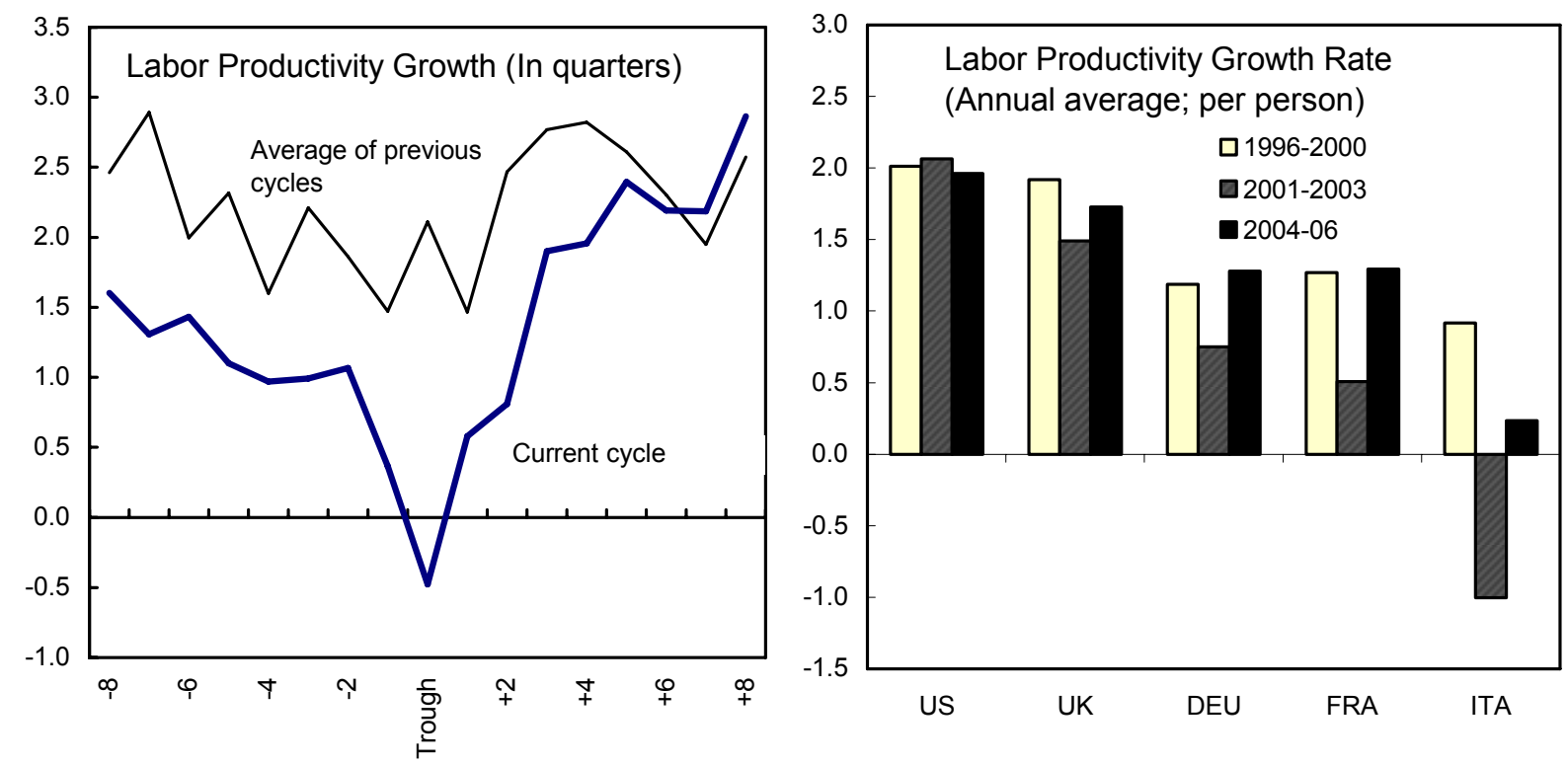

Medium-Term Projections, 2003-13

(Percentage change from the previous period, unless otherwise indicated)

\begin{tabular}{|c|c|c|c|c|c|c|c|c|c|c|c|}
\hline & 2003 & 2004 & 2005 & 2006 & 2007 & 2008 & 2009 & 2010 & 2011 & 2012 & 2013 \\
\hline Real GDP & -0.3 & 1.1 & 0.8 & 2.9 & 2.5 & 1.7 & 1.8 & 1.7 & 1.7 & 1.6 & 1.6 \\
\hline Total domestic demand & 0.6 & -0.2 & 0.3 & 1.9 & 1.1 & 1.5 & 2.0 & 1.8 & 1.8 & 1.8 & 2.0 \\
\hline Private consumption & 0.1 & 0.2 & -0.1 & 1.0 & -0.3 & 1.4 & 1.6 & 1.7 & 1.6 & 1.6 & 1.5 \\
\hline Gross fixed investment & -0.3 & -0.2 & 1.0 & 6.1 & 5.5 & 1.7 & 3.2 & 3.3 & 3.3 & 3.3 & 3.2 \\
\hline Foreign balance (contribution) & -0.8 & 1.3 & 0.5 & 1.1 & 1.5 & 0.3 & -0.1 & 0.0 & 0.1 & 0.0 & -0.2 \\
\hline Unemployment rate & 8.8 & 9.2 & 10.6 & 9.8 & 8.4 & 8.2 & 8.0 & 8.0 & 8.0 & 7.9 & 7.7 \\
\hline Employment growth & -0.9 & 0.4 & -0.2 & 0.7 & 1.7 & 0.6 & 0.4 & 0.3 & 0.2 & 0.2 & 0.2 \\
\hline $\mathrm{CPI}$ inflation & 1.0 & 1.8 & 1.9 & 1.8 & 2.3 & 2.1 & 1.9 & 1.8 & 1.8 & 1.8 & 1.8 \\
\hline \multicolumn{12}{|l|}{ Saving-investment balances $1 /$} \\
\hline Private & 3.2 & 5.6 & 5.5 & 4.4 & 3.4 & 3.6 & 2.7 & 2.3 & 2.0 & 1.4 & 1.2 \\
\hline Public & -1.3 & -1.3 & -1.0 & 0.7 & 2.2 & 1.6 & 2.1 & 2.2 & 2.2 & 2.6 & 2.5 \\
\hline Current account balance 1/ & 1.9 & 4.3 & 4.6 & 5.0 & 5.6 & 5.3 & 4.8 & 4.5 & 4.2 & 4.0 & 3.6 \\
\hline
\end{tabular}

Source: Fund staff estimates.

$1 /$ In percent of GDP.

\section{Policy Discussions}

\section{Against the background of short-term uncertainties and medium-term challenges, the discussions focused on:}

- $\quad$ strengthening employment and growth;

- $\quad$ safeguarding financial stability and reforming the financial sector; and

- $\quad$ consolidating fiscal progress to deal with near-term uncertainties and aging pressures.

17. The authorities were cautious about the likely pace of further reforms. They emphasized that recent policy measures had entailed sacrifices, generating a demand for "dividends." Staff cautioned against policy reversals and suggested that an appropriate balance was possible between efficiency and inclusiveness - to support growth, equity, and stability. Fairness is better achieved by continuing in the spirit of the Hartz IV reforms to 
focus on people rather than on specific labor market outcomes. Also, while maintaining their commitment to the Soziale Marktwirtschaft (social market economy), the authorities had allowed more options outside the framework of traditional institutions. Both sides agreed that striving for this balance would continue to prove fruitful.

\section{A. Strengthening Employment and Productivity}

18. Skills shortages need to be addressed. With a stronger labor market, a paradoxical phenomenon has emerged. While vacancies have increased, especially in skilled occupations, the inflow of immigrants to fill these positions has remained subdued, and highly trained Germans have chosen to seek employment elsewhere in Europe (Figure 10). The reasons for German emigration are complex and often specific to particular professions, but include a search for lower tax rates, higher returns to expertise, and more robust economic opportunities. These shortages are expected to increase rapidly with aging. The authorities agreed that a two-pronged strategy is necessary: invigorating education and training, and encouraging skilled immigration (Box 5). Immigration is politically sensitive, but restrictions for engineers from the new member states have been relaxed. 


\section{Box 5. Alleviating Shortages of Skilled Labor ${ }^{1}$}

\section{A dynamic general equilibrium model was used to simulate the long-term effects of} increasing the labor force by 100,000 persons a year (a 0.3 percentage point increase). The model incorporates demographics, life-cycle earnings, and savings dynamics. Skilled labor can be increased through domestic measures (such as retraining) or by increasing immigration. The two experiments lead to similar consequences for growth, but increased immigration also increases the size of the population and mitigates the aging problem; hence the focus on the latter scenario here.

\section{This annual increase in immigration of 100,000 adults compared with the baseline could} raise real GDP by 0.2 percentage point a year. With more adults joining the workforce, investment and capital stock would rise. A virtuous cycle of increases in income and consumption would then follow. The current account would deteriorate initially, but improve later as individuals start saving for retirement and older cohorts become more numerous.

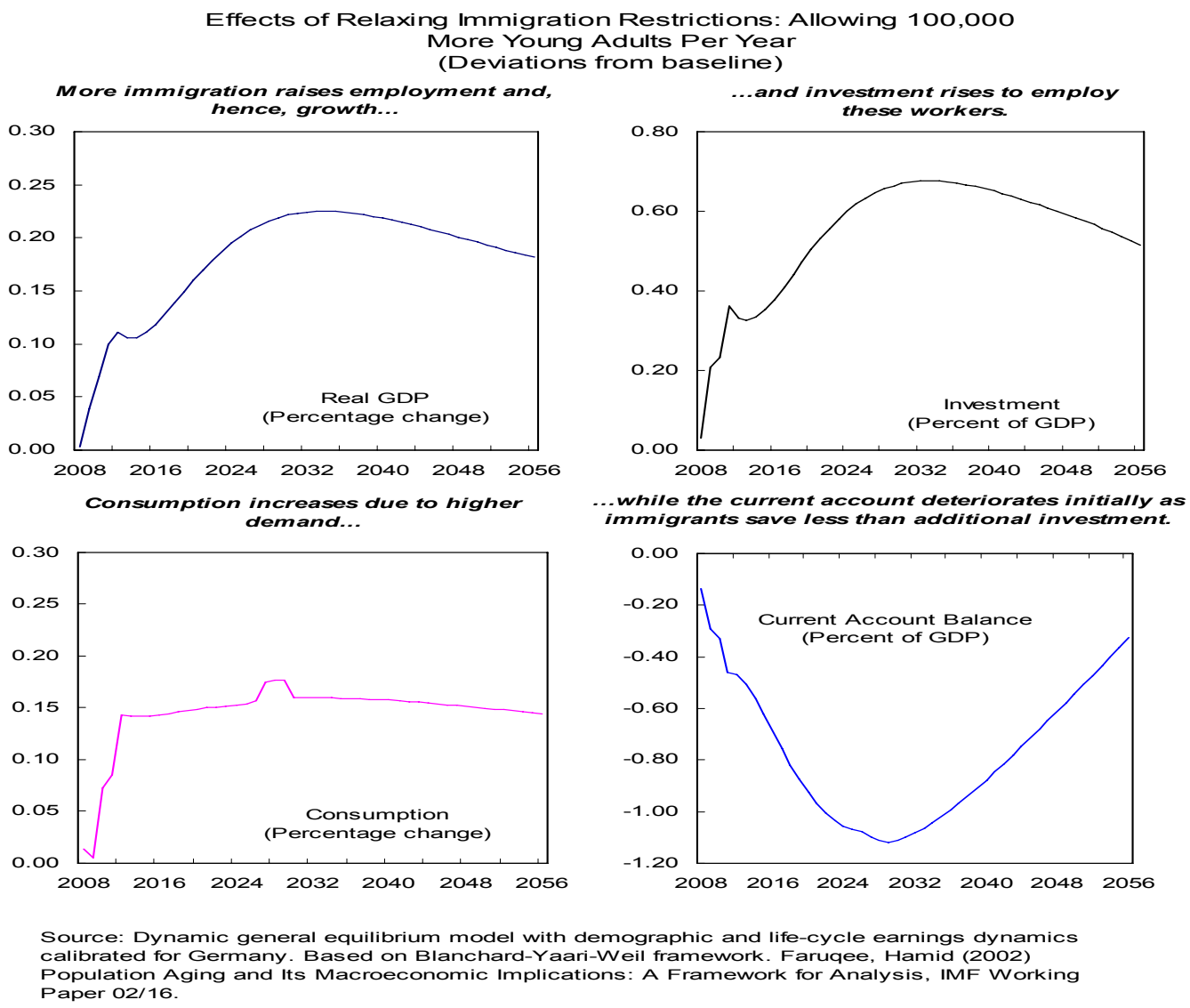

${ }^{1}$ See Selected Issues, Chapter III. 


\section{Staff cautioned that the remarkable turnaround on the labor market was} jeopardized by a misplaced focus on minimum wages to pursue social objectives. The authorities viewed the minimum wage for postal workers and extended unemployment benefits for the elderly as measures to achieve "fairness." Staff cautioned that wage floors were not an efficient instrument for social goals. The minimum wage for postal workers was already having unintended consequences: with competitors unable to match these wages, competition in postal services could be undermined. Additional sectoral minimum wages would raise the costs of, and reduce the demand for, low-skilled labor, especially in regions with endemic unemployment. Also, extension of the unemployment benefit period for older workers could open more such demands and signal a weakening commitment to improving incentives for work.
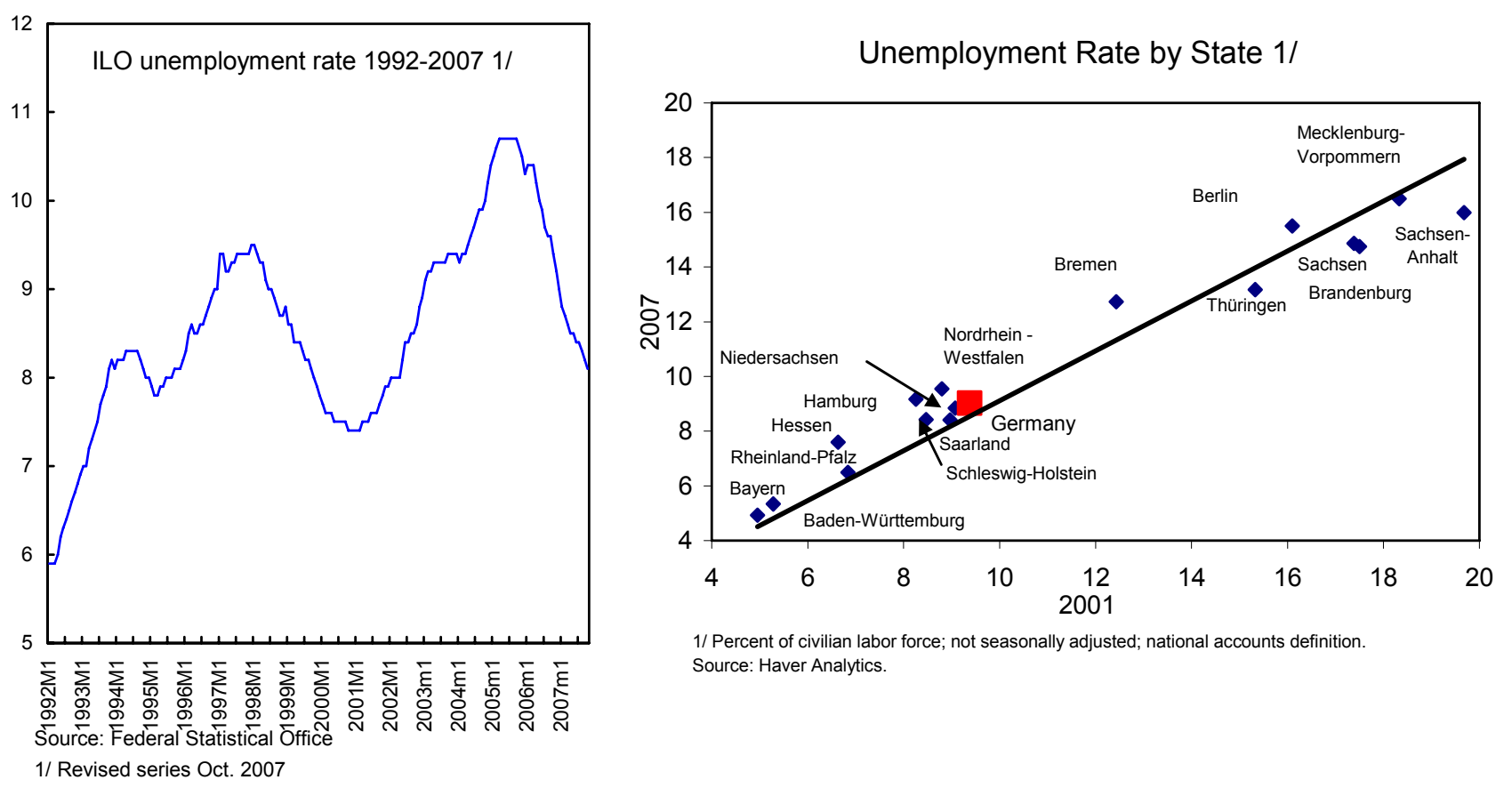

20. Perspectives on other labor market initiatives converged more. Staff supported the authorities' intent to rationalize job training and placement programs and urged more vigorous implementation. Staff also noted that the proposed child care programs will help increase the participation of women in the labor force, although care will be needed to keep them well targeted.

\section{The authorities agreed that a broad range of measures are needed to boost the} investment climate. They reported progress in the efforts of the national Normenkontrollrat as part of the government's program to reduce red tape and simplify regulations. They recognized that reducing the corporate tax rate (which remains one of the highest in Europe) and tax wedge on labor would eventually be desirable, but noted that, following the measures 
recently undertaken, a further fiscally responsible reduction in capital and labor taxes was not feasible in the short run. They were clear that any amendments to the Foreign Trade and Payments Act would be undertaken in a manner that preserves Germany's long-standing reputation for openness to foreign capital. Staff also noted that a financial sector that efficiently finances innovation can complement the high patent rates to spur growth while also improving economic welfare by allowing greater consumption smoothing than recently achieved (text figure).

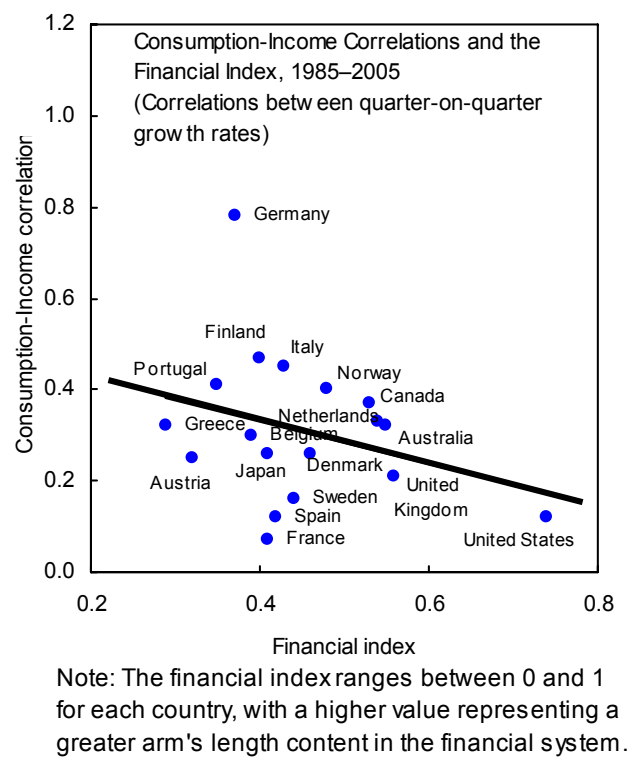

\section{B. Financial Sector Stability and Efficiency}

22. The ongoing turbulence has served as a wake-up call. Despite the progress achieved, long-standing concerns about the relatively low profitability of the still-fragmented banking system have - by creating incentives for excessive risk taking - intersected with new concerns about financial stability (Tables 3 and 4 ). ${ }^{2}$ The size of the capital market and its ability to enhance efficient allocation of resources and improve consumption smoothing leave room for considerable progress.

\section{Against this background, the mission held extensive discussions on financial sector issues, with emphasis on:}

- $\quad$ banking sector restructuring;

- $\quad$ crisis prevention and management;

- $\quad$ supervision; and

- $\quad$ continued strengthening of capital markets.

\section{Banking sector restructuring}

24. Both sides were concerned that, absent further banking sector restructuring, systemic and fiscal risks could rise. In line with international trends, the number of banks has fallen sharply in recent years and the number of employees per bank has increased (Table 5 and text table). The sector's fragmentation contributes to low interest rate margins and still modest income from nonbanking services (Figure 11). Banks unable to generate adequate profits are likely to take on greater risks. The recent turbulence has again raised the

\footnotetext{
${ }^{2}$ See Germany: Selected Issues, IMF Country Report No. 06/436.
} 
question of whether many banks, especially the Landesbanken, have viable business models. Although the banking and financial system faces major challenges, the authorities stressed that it had nonetheless proved to be stable and functionally viable, even in a clearly stressful operational setting. They recognized, however, that the domestic banking system could come under further pressure with the globalization of finance and the framework set by European competition policies. Besides creating wider systemic concerns - as it briefly did this past summer - staff noted that the fragility also generates contingent fiscal liabilities, which can turn only too real as in the case of the State of Saxony, Sachsen LB's owner.

\begin{tabular}{lrrrrr} 
& \multicolumn{2}{c}{$\begin{array}{c}\text { Number of credit } \\
\text { institutions }\end{array}$} & & \multicolumn{2}{c}{$\begin{array}{c}\text { Employment per institution } \\
\text { (Persons) }\end{array}$} \\
\cline { 2 - 3 } \cline { 5 - 6 } Country & 1997 & 2006 & & 1997 & 2006 \\
\hline Belgium & 131 & 105 & & 585 & 647 \\
Denmark & 213 & 191 & & 226 & 243 \\
Germany & 3,420 & 2,050 & & 224 & 338 \\
Greece & 55 & 62 & 1,031 & 1,003 \\
Spain & 416 & 352 & 591 & 744 \\
France & 1,258 & 829 & & 329 & 525 \\
Ireland & 71 & 78 & & 502 \\
Italy & 909 & 807 & & 377 & 421 \\
Luxembourg & 215 & 154 & 89 & 161 \\
Netherlands & 648 & 345 & 172 & 338 \\
Austria & 928 & 809 & 80 & 94 \\
Portugal & 238 & 178 & 271 & 327 \\
Finland & 348 & 361 & 77 & 66 \\
Sweden & 237 & 204 & 182 & 231 \\
United Kingdom & 537 & 401 & 848 & 1,130 \\
\hline
\end{tabular}

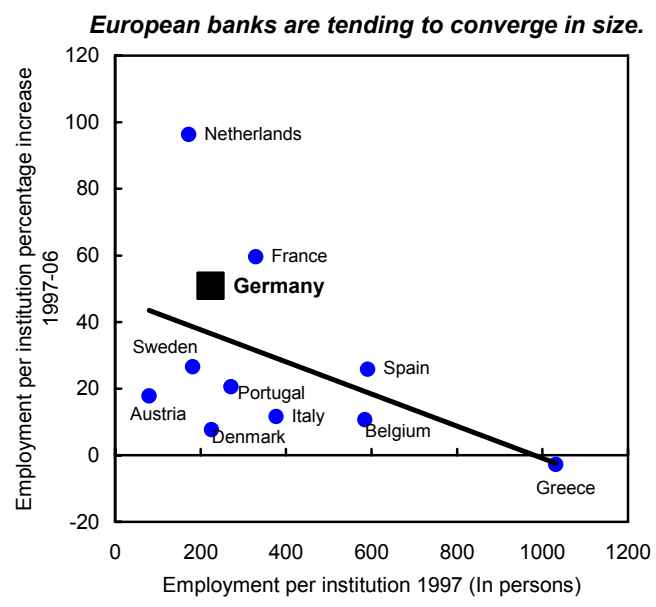

Source: European Central Bank.

25. However, views differed on how to achieve further restructuring. Staff

supported a market-based process of takeovers and exits, cautioning that the current ad hoc approach to public mergers may not achieve viable business models. Policy measures must, therefore, ensure that market forces and private capital can play their legitimate role. The authorities saw scope for restructuring through consolidation mainly within "pillars" in the three-pillar system of private, state-owned, and cooperative banks. Indeed, some of the stronger Landesbanken have forged deeper vertical links with the local Sparkassen (savings banks) and, as such, are thought to be viable. But staff argued that these vertically integrated but regionally oriented banks may not offer a long-term solution. Policy commitment to such vertical, state-based silos could prove unsustainable and pressure for market-based restructuring will continue to increase in an era of global finance and the European Commission's initiatives to create a framework for integrating retail financial markets in the context of its financial services policy. The authorities recognized that breaking the regional restrictions for the Sparkassen may be needed. However, given the rights of the Länder, the federal authorities noted their constraints in influencing the process. Staff nevertheless sees a role for the federal authorities in pushing the reform agenda and cautioned that interim measures (for example, vertical integration within the public pillars) could have unintended consequences that close future restructuring option 


\section{Crisis prevention and management}

\section{The authorities regarded the developments at Sachsen LB and IKB as}

unforeseeable "tail events." While staff was concerned about gaps in the Germany supervisory system, and the authorities did recognize gaps that needed to be addressed, they nevertheless stressed that the problems at the two banks that needed to be rescued were the consequence of failures in mortgage origination in the United States and an internationally accepted rating methodology. The unusual nature of the banks' off-balance-sheet activities and the liquidity commitments to their conduits were, at least in broad terms, known to the Bundesbank and Bundesanstalt für Finanzdienstleistungsaufsicht (BaFin), but were not viewed as alarming at the time. As elsewhere, the risk that the commercial paper market could freeze up was not recognized.

27. They agreed, however, that more transparency was needed. Looking ahead, staff recommended that supervisors should require banks to file financial statements on a quarterly basis and encourage a more widespread use of IFRS reporting (which mandates consolidation of group activities). The authorities agreed that regular stress tests, which were sensitive to the newly revealed vulnerabilities, were needed. They noted that the SarkozyMerkel-Brown initiative and the Ecofin decisions will likely establish further norms for enhancing transparency and other arrangements for financial stability.

\section{Staff argued for a bank resolution framework with better incentives for} prudent operations. As the two German banks felt the full force of the U.S. subprime crisis, rapid action by the authorities helped preserve confidence in the system. Nevertheless, broader questions about Germany's resolution policy remain. The authorities noted that measures to contain the damage from potential bank failures sought to balance the need for quick action with maintaining incentives for prudent behavior by bank managers and owners. The authorities explained that, in the case of IKB, private shareholders stakes had not been diluted, in part because the process would have entailed considerable delays under the corporate insolvency procedures. Staff recommended that the German insolvency framework should recognize the role of banks in the payment system and the macro economy and incorporate greater flexibility to allow for quick resolutions and dilution of the equity claims of all shareholders.

\section{Supervision}

\section{Prompted by recent events, the authorities are reviewing ways to improve} coordination between BaFin and Bundesbank. BaFin is the consolidated financial sector supervisor, similar to that found in some other countries. Enforcement actions can only be taken by BaFin based on its sole determination of the circumstances at a bank. Under the law, the Bundesbank performs on-site and off-site monitoring of banks under the guiding principles issued by BaFin in agreement with the Bundesbank. BaFin can accompany Bundesbank staff and can also commission auditors to perform special audits. These overlapping mandates have been viewed by banks as unnecessarily duplicative. More 
important, the coordination problem inherent in the existing structure weakens accountability and risks poor decisions and delays in problem situations. The Finance Minister has called on BaFin and the Bundesbank to revise the above-mentioned guiding principles.

\section{Though agreeing that enhanced supervisory accountability should be a} principal objective, the authorities were not persuaded by staff's structural suggestions. Staff recommended that accountability would be increased by consolidating supervision of banks in one of the two agencies. The supervising agency should also have enforcement powers to lower a bank's risk profile, recognizing that the ultimate step of closing a bank could require a joint decision involving the Ministry of Finance. Thus, if the Bundesbank were to supervise, BaFin would retain its regulatory role, but not its enforcement powers. If accountability were better achieved by consolidating supervision under BaFin, the Bundesbank would still need full access to information on systemically important banks and on other banks as needed, given its financial stability and lender-of-last-resort responsibilities. The authorities were not persuaded that such a consolidation of supervision was practical. Giving the Bundesbank additional authority would, they felt, dilute the BaFin model of integrated supervision. And BaFin could not in the near term take on the full task of supervision, especially given the need to attract skilled supervisors at premium wages. Staff conceded that even a partial streamlining of the current arrangement could improve accountability but remained concerned that coordination problems would continue.

\section{Under any arrangement, the urgent need for upgrading supervisory capability}

is evident. IFRS and Basel II should help deal with evolving issues of greater transparency and liquidity risks, but new challenges will also arise. The Capital Requirements Directive (CRD) will fully introduce Basel II in Europe from 2008. Pillar 2 of Basel II requires a more integrated approach to risk management, and pillar 3 fosters further disclosure.

Implementation will require establishing new norms, including on the extent and frequency of disclosure (especially of complex financial products), management of liquidity through access to adequate contingent funds, and increased emphasis on the use of risk models and management. With the growing sophistication of financial markets and the complexities introduced by Basel II, the authorities agreed that the reliance on external auditors must decline with stepped-up efforts to attract and retain skilled supervisors. The same skills will be demanded by banks. The 9 percent add-on to civil service salaries available to the Bundesbank's staff, flexible contracts that offer targeting of specialized skills, and training programs are the authorities' means to deal with these challenges.

\section{Capital markets}

\section{Despite steps taken to strengthen capital markets, these remain} underdeveloped and not widely used for investment by firms and households. Traditionally, Germany has had a significant public bond market. The stock market, though still small, has made strides helped by regulatory easing, with greater liquidity and more new capital raised (Figure 12). Yet the equity market is dominated by relatively few firms and the 
share of closely held stocks remains high (Figure 13). Also, despite progress, Germany lags in nontraditional sources of financing, including nonbank intermediation and asset-backed securitization (Figure 14). The authorities noted that barriers to domestic asset securitization and flexibility of mortgage markets had been essentially removed, including through the recent introduction of real estate investment trusts. The continuing lag in Germany's capital markets

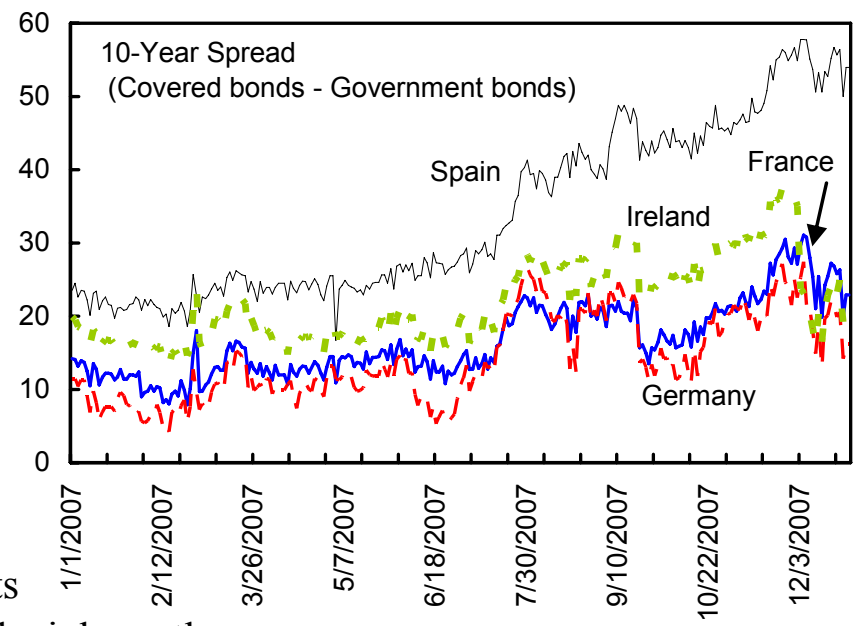
was seen by them as reflecting inertia and the inherently conservative financial preferences of the population. The authorities noted that the conservatism was something of a blessing in the second half of 2007. Notably, even through the recent market turmoil, Pfandbrief credit spreads traded below benchmark yield curves, whereas other covered bond spreads widened by up to 50 basis points.

33. Further corporate governance reforms would add impetus to capital market development and investments in productivity growth by firms. A comparison across OECD economies suggests that German companies achieve relatively low market value in relation to their investments (text figure). Both internal and external controls on company management can potentially be strengthened. First, the operation of the two-tier (supervisory and management)

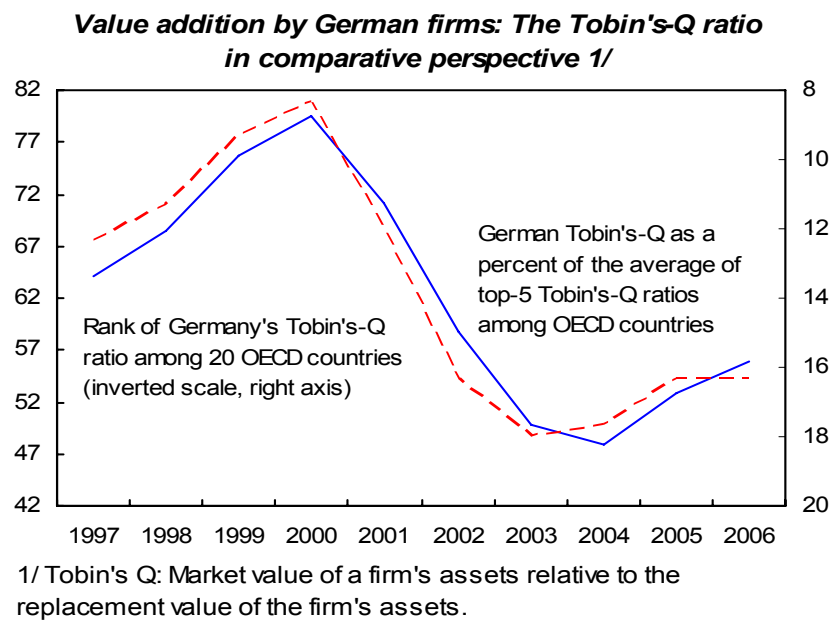
board structure at many companies is widely viewed as cumbersome, if not ineffective. Recent studies point to the crucial importance of efficiently functioning boards for value maximization and productivity growth. The authorities noted that several supranational companies (text table below), responding to global pressures, had exercised the option of operating either under a one-tier board or smaller board sizes permitted under the 2004 law governing the Societas Europea (the European Company Law) and such an option could be extended to a wider range of companies. ${ }^{3}$ Second, continued ownership concentration, albeit declining, creates the risk of

\footnotetext{
${ }^{3}$ The issue of codetermination - the representation of labor on the supervisory board in large companiesremains politically contentious. See Selected Issues, Chapter IV.
} 
self dealing - diversion of assets by insiders at the cost of minority shareholders. While selfdealing transactions need to be declared in an annual report, staff suggested that the current practice of limiting the availability of this report to the supervisory board should be changed and the report distributed to all shareholders to strengthen internal control. The authorities were concerned that lengthy court proceedings related to self-dealing could undermine shareholder rights. Finally, while they agreed that activity in the takeover market remained sluggish, they were less concerned than staff about management's scope for defensive measures.

German Societas Europea: Changes in Board Structure

\begin{tabular}{lrlcl}
\hline SE & Employment & Board Structure & $\begin{array}{c}\text { Labor Participation in } \\
\text { Supervisory Board }\end{array}$ & $\begin{array}{c}\text { Labor Participation } \\
\text { Rights }\end{array}$ \\
\hline Allianz & 177,000 & Two-tier & 6 out of 12 & Yes \\
Conrad Electronic & 2,314 & One-tier & Not applicable & No \\
Donata Holding & 3,922 & One-tier & Not applicable & No \\
Fresenius & 100,000 & Two-tier & 6 out of 12 & Yes \\
MAN Diesel & 6,625 & Two-tier & 5 out of 10 & Yes \\
PCC & 3,756 & One-tier & Not applicable & No \\
Porsche Holding & 11,500 & Two-tier & 6 out of 12 & Yes \\
Surteco & 2,109 & Two-tier & 3 out of 9 & Yes \\
\hline
\end{tabular}

Source: ETUI-REHS.

34. New governance initiatives carry risks. Staff expressed concern that the draft Risk Limitation Law may create legal uncertainties and stifle legitimate shareholder opposition to management. The authorities agreed on the need to ensure a level playing field, and intend to clarify the draft in this respect. The authorities were aware of views that the draft Law on Modernizing the Framework for Venture Capital and Private Equity could have been stronger, to establish a unified legal and regulatory framework for this important industry. They pointed to the need of targeting the law at those activities that truly merit tax relief. Staff acknowledged that a more far-reaching law would result in higher revenue losses, another reason for continued expenditure moderation to accommodate such initiatives. Staff also cautioned against the proposal to introduce profit sharing, which, though consistent with the authorities' objective of Soziale Marktwirtschaft, could further complicate corporate governance. Such arrangements might be best undertaken on a voluntary basis rather than through legislation.

\section{Strengthening Public Finances}

\section{After absorbing the costs of two tax reforms in 2008, the authorities plan to} achieve a structural surplus of $1 / 2$ percent of GDP by 2011. Following structural balance in 2007 , the current year's budget is projecting a deficit of more than $1 / 2$ percent of GDP. The deterioration is primarily due to two tax measures: a corporate income tax reform $(0.3$ percent of GDP) and a reduction of the unemployment insurance rate from 4.2 to 3.3 percentage points of personal income ( 0.2 percent of GDP). Healthcare reform and research and development subsidies will increase spending by 0.1 percent of GDP. Moving forward, 
in their latest Stability Program, the authorities have set the medium-term target of a structural surplus of $1 / 2$ percent and a primary surplus of $3 \frac{1}{2}$ percent of GDP. Achieving this objective would aid long-term sustainability; in fact, the present discounted value of government's net worth would be almost balanced assuming that such adjustment is maintained and, importantly, that the authorities' estimates of aging costs hold (text table balance sheet).

\section{The slippage in $\mathbf{2 0 0 8}$ is regrettable and achieving the appropriately ambitious}

medium-term goals remains a challenge. To be sure, the benefits from past reforms will continue to pay dividends. Thus, changes in the pension formula for benefits and indexation of long-term care benefits will achieve incremental reductions over time. The expenditure containment will continue through public sector wage moderation and the phasing out of homeowners subsidies. Nevertheless, staff estimates that the accumulated shortfall by 2011 in the primary balance goal could be as much as 1 percent of GDP on announced policies (Table 6). If the many real risks to revenues and

Risks to overall fiscal balance are linked to growth risks, and implementation of reforms.

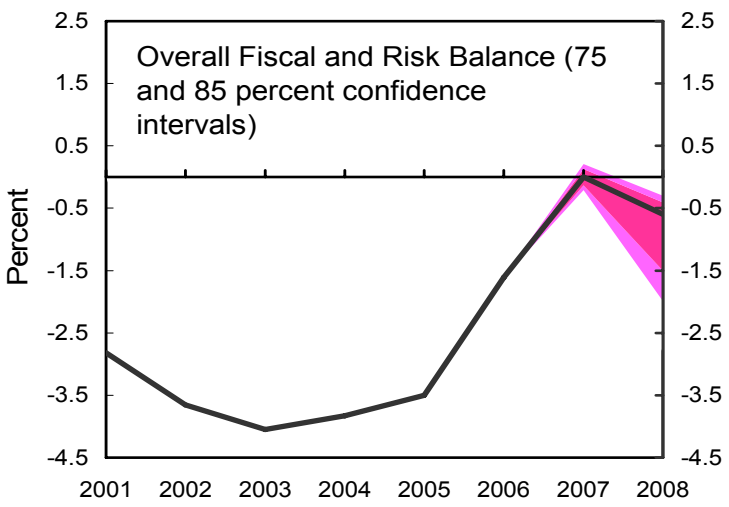

expenditures - such as those from lower growth and higher-than-expected losses from the corporate income tax reform - also materialize, the shortfall would be even larger. In particular, corporate taxes tend to increase on the upswing, but can decrease dramatically during a downturn. As such, the downside risks to growth create a corresponding risk to fiscal outcomes, even in structural terms.

\begin{tabular}{|c|c|c|c|c|c|c|}
\hline \multicolumn{7}{|c|}{$\begin{array}{c}\text { General Government Fiscal Position } \\
\text { (Percent of GDP) }\end{array}$} \\
\hline & \multirow[b]{2}{*}{2003} & \multirow[b]{2}{*}{2004} & \multirow[b]{2}{*}{2005} & \multirow[b]{2}{*}{$2006^{-}$} & \multicolumn{2}{|c|}{ Proj. } \\
\hline & & & & & 2007 & 2008 \\
\hline Overall balance & -4.0 & -3.8 & -3.5 & -1.6 & 0.0 & -0.6 \\
\hline $\begin{array}{l}\text { Revenue } \\
\text { of which }\end{array}$ & 44.5 & 43.3 & 43.5 & 43.8 & 44.0 & 43.2 \\
\hline Direct taxes & 10.4 & 10.0 & 10.1 & 10.8 & 10.9 & 10.6 \\
\hline Indirect taxes & 11.8 & 11.8 & 11.8 & 12.1 & 12.9 & 12.8 \\
\hline Primary expenditure & 45.5 & 44.3 & 44.1 & 42.6 & 41.3 & 41.1 \\
\hline $\begin{array}{l}\text { Social benefits } \\
\text { of which }\end{array}$ & 27.5 & 26.8 & 26.6 & 25.8 & 25.0 & 24.7 \\
\hline Pensions & 12.4 & 12.2 & 12.0 & 11.6 & 11.1 & 10.9 \\
\hline Health & 7.7 & 7.4 & 7.5 & 7.4 & 7.4 & 7.5 \\
\hline Other expenditures & 18.1 & 17.5 & 17.5 & 16.8 & 16.3 & 16.5 \\
\hline Structural balance & -3.2 & -2.8 & -2.4 & -1.2 & 0.0 & -0.7 \\
\hline
\end{tabular}




\section{Staff therefore proposed that additional measures be taken to create a} precautionary buffer. Since delays in achieving the primary balance target have longlasting implications, identifying and implementing subsidy-cutting measures and rationalization of tax expenditures remain important tasks - also to create the room for reducing tax rates in a responsible manner. Although the Stability Program identifies potential savings from a wide range of measures, the authorities felt that the likelihood of their implementation was low, given the current "reform fatigue." If, however, the risks to the fiscal position did materialize, there could be more appetite for these measures.

\section{Securing a sound fiscal position today will protect against the risk that}

healthcare costs have been underestimated. While pension reforms have helped greatly, the authorities recognize that the costs from healthcare will pose an increasing burden. Since the trajectory of the public debt-to-GDP ratio is very sensitive to long-term assumptions (text table $^{4}$ and Figure 15), higher rates of cost increase implying rapid debt accumulation. Staff was concerned that the authorities' forecast of a rise in healthcare costs of 1.2 percentage points of GDP over the next 45 years may be too low. Other estimates show increases of up to 5.6 percent of GDP (for example, the IFO Institute), while staff considers a 3.0 percent of GDP increase as highly likely, given past cost dynamics, the structure of age-related benefits, and the costs of new treatments. The authorities plan to review their estimates in the context of the 2008 long-term sustainability report.

\footnotetext{
${ }^{4}$ Traa, Bob, 2006, “A Long-Run Fiscal Baseline and Indicative Public Sector Balance Sheet”, paper presented at the Long-Run Fiscal Sustainability in Germany Berlin symposium.
} 
General Government Indicative Balance Sheet for 2007

(In percent of GDP)

\begin{tabular}{|c|c|c|c|c|c|}
\hline & $\begin{array}{r}\text { Authorities' } \\
\text { Scenario }\end{array}$ & \multicolumn{4}{|c|}{ Alternative Scenarios } \\
\hline & $\begin{array}{r}\text { Low Aging } \\
\text { Costs and } \\
\text { Planned } \\
\text { Adjustment by } \\
20111 /\end{array}$ & $\begin{array}{r}\text { Medium Aging } \\
\text { Costs and } \\
\text { Planned } \\
\text { Adjustment by } \\
20112 /\end{array}$ & $\begin{array}{c}\text { Large Aging } \\
\text { Costs and } \\
\text { Planned } \\
\text { Adjustment by C } \\
20113 /\end{array}$ & $\begin{array}{r}\text { Medium Aging } \\
\text { Adjustment 4/ }\end{array}$ & $\begin{array}{r}\text { Large Aging } \\
\text { Costs and } \\
\text { Slower } \\
\text { Adjustment } 5 /\end{array}$ \\
\hline Comprehensive net worth=budget constraint $6 /$ & -3 & -25 & -93 & -44 & -110 \\
\hline Comprehensive financial net worth $7 /$ & -55 & -77 & -145 & -96 & -162 \\
\hline
\end{tabular}

Sources: Ministry of Finance, and Fund staff calculations.

1/ Primary surplus of $31 / 2$ percent of GDP achieved by 2011 (see Stability Program Dec. 2007) and 1.2 percent of GDP increase in public expenditures on health benefits due to aging over 2004-2050 (corresponding to 2.7 percent of GDP total aging costs, AWG). 2/ Primary surplus of $31 / 2$ percent of GDP achieved by 2011 (see Stability Program Dec. 2007) and 3.0 percent of GDP increase in public expenditures on health benefits due to aging over 2004-2005 (corresponding to 4.0 percent of GDP total aging costs). 3/ Primary surplus of $31 / 2$ percent of GDP achieved by 2011 (see Stability Program Dec. 2007) and 5.6 percent of GDP increase in public expenditures on health benefits due to aging over 2004-2005 (corresponding to 7.8 percent of GDP total aging costs, IFO current projections. See Martin Werding presentation at Joint IMF-Bertelsmann Foundation Conference, Berlin, Nov. 2006 on Long-term Sustainability of Public Finances in Germany).

4/ Primary surplus of $21 / 2$ percent of GDP achieved by 2011 (see IMF projections, Table 3) and 3.0 percent of GDP increase in public expenditures on health benefits due to aging over 2004-2005 (corresponding to 4.0 percent of GDP total aging costs). 5/ Primary surplus of 2 1/2 percent of GDP achieved by 2011 (see IMF projections, Table 3) and 5.6 percent of GDP increase in public expenditures on health benefits due to aging over 2004-2005 (corresponding to 7.8 percent of GDP total aging costs, IFO current projections. See Martin Werding presentation at Joint IMF-Bertelsmann Foundation Conference, Berlin, Nov. 2006 $6 /$ Defined as current financial and nonfinancial wealth and net present value of debt projections of fiscal scenarios for a rolling 50-year period; based on 2007 population projections Federal Statistical Office.

7/ Excludes the nonfinancial net worth as many such assets may not be marketable. Therefore, they would not be available to alleviate the public sector liquidity constraint.

39. Several options to deal with aging costs were discussed. Staff proposed that a more automatic tie between the retirement age and population longevity would contain the growth of pension outlays under the first pillar. Also, the second pension pillar, linked to the individuals' employment, limits the employees' risk diversification and serves implicitly to subsidize the employer. Hence, more options to place employee savings into financial instruments, as in the third pillar, would help. Addressing the greater challenge of escalating healthcare costs, the authorities noted, would require stronger incentives for cost savings by insurers. This would require revisiting the arrangements through which insurers are reimbursed by the Health Fund. They also recognized that, while ensuring basic health coverage for all, the private burden for traditionally publicly financed services would have to continue to rise to ensure the sustainability of the social security system.

\section{Past breaches of the Maastricht budget deficit criteria and enforcement} problems with the existing fiscal rule have led to a review of the fiscal framework. The existing "golden rule" requires that borrowing at the central government level not exceed gross investment. With reduced public investment needs, the rule implies a close-to-balance budget, leaving little room for automatic stabilizers; it has lost credibility since an escape clause (declaration of macroeconomic disequilibrium) was repeatedly invoked. The authorities have proposed a new fiscal rule, which calls for a (close to) structurally-balanced budget for the central government and states every year but with some room for the operation of automatic stabilizers. Staff agreed that the new rule would be better aligned with the 
Stability and Growth Pact and would serve to anchor and improve incentives for fiscal selfdiscipline. Staff recommended, in addition, that the rule should require further belt tightening when necessary for long-run sustainability. Moreover, the effectiveness of the rule will depend on how the discretion is used — or abused. Imparting greater transparency remains crucial. In this regard, staff welcomed the authorities' effort to embed more systematic program evaluation into fiscal decisions (for example, assessment of tax expenditures, as presented in the Stability Program) but also called for standardized fiscal reporting at all levels of government.

41. Reform of fiscal federalism is also needed. The medium-term fiscal targets are based on the assumption of budget surpluses at the subnational level. Ensuring this goal requires increased fiscal efficiency at the subnational level, necessary also to control subnational debt and prevent budget crises. The authorities and staff shared the diagnosis. The current system, based on the cooperative principle of uniform spending standards, is inefficient and is also not achieving the authorities' goal of greater equality across states (Box 6). Spending is financed by horizontal transfers across the Länder (primarily from shared taxes with the federal government), together with vertical transfers from the federal government. Most Länder have few incentives to manage their public finances efficiently, given the rigidity in spending, the limited authority over tax policy, and a de facto bailout guarantee. The system encourages unproductive tax competition through Länder tax administration decisions. The arrangement is under stress, with the surplus Länder disinclined to subsidize those with deficits.

42. But the politics for achieving the needed reforms is unfavorable. Greater Länder tax autonomy (for example, by allowing them to set personal income tax rate surcharges within defined bands), along with centralization of tax administration, could help establish greater accountability at the subnational level. As international experience shows, tax autonomy and clarification of obligations at different levels of government would also improve effectiveness of local service delivery while maintaining the objectives set within a cooperative framework. Finally, timely and consistent data on Länder finances, including on subnational debt, are needed for transparency and monitoring of general government finances. The difficulty is that each measure, taken in isolation, faces considerable opposition from a number of states. A package of measures in line with other countries' experiences may help achieve the necessary compromises to move ahead on the broad agenda. 


\section{Box 6. Why Has Economic Convergence Across the Länder Stopped? ${ }^{1}$}

Following reunification, consumption across German states converged rapidly at first (figure; larger negative numbers imply faster convergence). But the convergence rate has declined steadily, and recently there has actually been divergence (positive values on the convergence axis). Because consumption growth rates are now similar across states, citizens in poorer states are not catching up but have greater insurance: a temporary decline in income does not imply a corresponding decline in consumption.

\section{Why has the rate of convergence declined?} Following reunification, investment flowed to

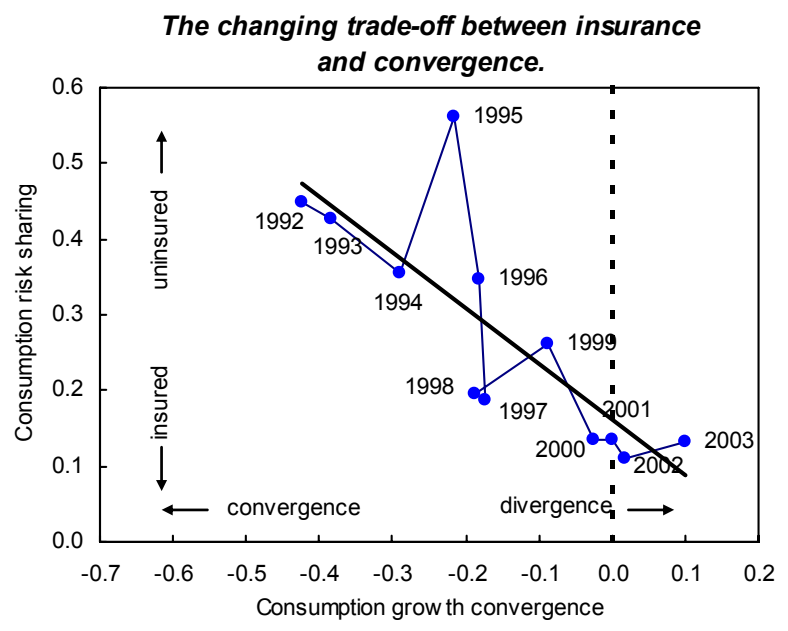
the poorer states, helping capital accumulation and raising labor productivity and growth (figure below).
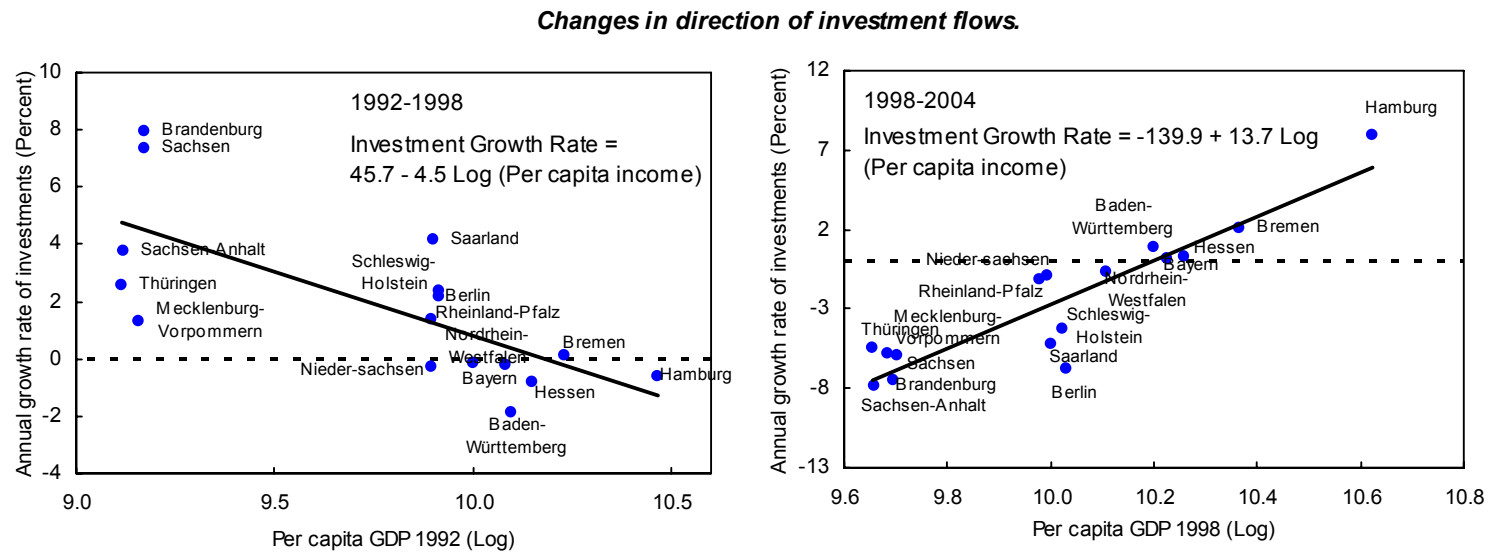

However, since the late 1990s, the richer states are achieving higher investment growth rates, reinforcing their already high incomes. The data suggest that, despite increased productivity in the poorer states, their high wages have implied high labor shares of income. In turn, the lower profitability has apparently resulted in low (even negative) investment growth rates.

${ }^{1}$ Prepared by Akito Matsumoto.

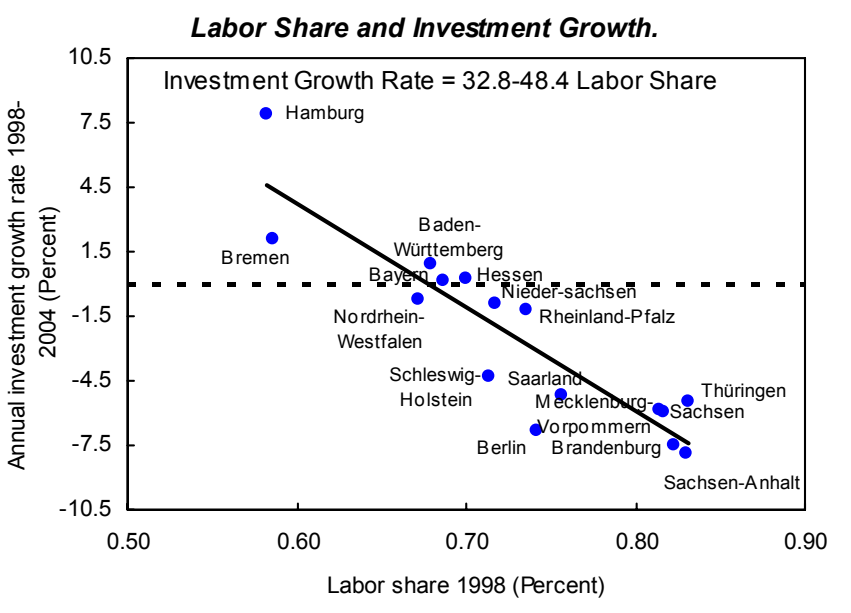




\section{Staff Appraisal}

43. Bold reforms have strengthened the German economy. From the economic doldrums early in the decade, Germany has made valuable gains. These include strong GDP growth, substantial employment gains, an impressive increase in the share of longer-term jobs with social security benefits, and fiscal position in the best shape since unification. Wage moderation helped competitiveness, in turn, allowing firms to profit from the global upswing. With the improved competitiveness, the real exchange rate is estimated to be close to equilibrium, with some evidence of a modest undervaluation.

\section{The economy has so far withstood the financial turmoil—but downside risks}

are substantial. Strong cyclical bank profitability before the turbulence and the low reliance of enterprises and households on credit have helped maintain normalcy in lending. Writedowns have continued as assets have had to be revalued, but systemically important banks have dealt with these without impairing their core capital. However, the tightening lending standards and the deepening turbulence raise the risk of a cascading decline in lending and growth.

45. To protect against the unfolding risks and build on the hard-won gains, the outstanding challenges must be tackled. The authorities have stepped up their assessment of bank exposures to credit and liquidity risks, a vigilance that must continue in view of the yet unknown dimensions and fast-moving nature of the current turmoil. A significant unfinished policy agenda remains - in labor markets, the general investment climate, financial sector stability and efficiency, and fiscal policy. Persevering with this agenda holds the enticing promise of substantial improvements in living standards for all. This goal can be met by fostering efficiency and growth, while enhancing the sustainability of the Soziale Marktwirtschaft (social market economy).

46. A pause in the broader reform process would be unfortunate, and reversals risk undermining the gains achieved. In the second half of the electoral cycle, the next generation of reforms will no doubt confront difficult political challenges and pressures for a front-loaded sharing of the "reform dividend." However, economic performance in the current cycle has not yet been evidently stronger than in past upswings. Moreover, the recent strength has been aided by an unusually long and strong global cycle. As such, continuation of the buoyant performance is far from assured.

\section{Enhancing Germany's growth potential and resilience requires interrelated}

measures. To alleviate skills shortages, a two-pronged strategy is necessary: invigorating education and training, and encouraging skilled immigration. Sectoral minimum wages will not serve the goal of fairness and risk distorting competition; and diluting work incentives could hurt the progress of Hartz IV. Instead, more vigor in rationalizing active labor market and placement assistance programs and enhanced child care availability for women to participate in the labor force would strengthen the labor market. Finally, the investment 
climate would be strengthened by continued reduction of red tape, a reduction of taxes on capital and labor (offset by expenditure reductions), and preserving Germany's reputation for openness to foreign capital.

\section{Policy on banking sector restructuring should be mindful of, and consistent} with, the forces of international financial integration. The recent events highlighted the concern that the fragmented banking structure generates only modest profits and, therefore, creates incentives that risk destabilizing the system. Measures to foster bank restructuring should be guided by the goal of creating robust and sustainable banks, while allowing private capital to play its role. As global competition intensifies, eroding the traditional businesses of banks that only serve targeted communities, their market share will likely continue to diminish and the structure of German banking will evolve. While such localized services are important, these banks should operate in response to market demand. Where political compromises are made, these should not be at the cost of constraining future options.

49. Greater transparency and stronger incentives for prudent action will support crisis prevention and management. The bank resolution framework should allow for quick resolution but improve management incentives by allowing for dilution of private shareholders' equity. Supervisors should require more frequent financial statements and encourage more widespread use of IFRS reporting to better capture off-balance-sheet activity.

50. Structural and coordination improvements are needed for enhancing supervisory accountability. Consolidation of bank supervision and prudential enforcement in either the Bundesbank or BaFin would increase accountability. Regulation will need to stay with BaFin to maintain its role as a consolidated supervisory agency and, under any supervisory arrangement, the Bundesbank would need all necessary information to fulfill its financial stability and lender-of-last-resort responsibilities. Effective implementation of Basel II will require reduced reliance on external auditors and stepped-up efforts to attract and retain skilled supervisors.

\section{The further development of capital markets will be aided by creating} additional options for, and greater transparency in, corporate governance. Such steps that hold the promise of raising economic productivity. In particular, the large size of the supervisory boards slows decisions. The option available to some German companies for rationalizing their boards under the Societas Europea rules could be more widely extended. Internal and external discipline can also be fostered through further improvements in disclosure standards, especially on board members' financial dealings, and by lowering barriers to takeovers. A number of new initiatives in the pipeline carry risks of further strengthening insiders or rendering governance more complex.

52. Building on their significant recent achievements, achieving fiscal sustainability is within reach —and the ingredients for doing so are clear. Although the fiscal situation 
is expected to deteriorate mildly in 2008 , the incremental gains from measures already taken should help continued consolidation. Additional measures now will help mitigate the shortterm risks, especially those from an asymmetric decrease in revenues were growth to decline sharply. Because short-term slippages accumulate, precautionary belt tightening will also aid long-term sustainability. In that regard, tackling healthcare expenditures is the priority. The authorities' move to a fiscal rule that achieves close to structural balance is in the right direction, but the rule should also allow for additional measures for preserving long-term sustainability. The second round of fiscal federalism reforms offers the opportunity for a significant increase in efficiency and mitigation of fiscal risks. A package of measures that includes centralized tax administration but increased Länder autonomy on tax policy would create better incentives for fiscal management.

53. It is proposed that the next Article IV consultation be held on the standard 12-month cycle. 
Figure 1. Germany: Exports and Competitiveness
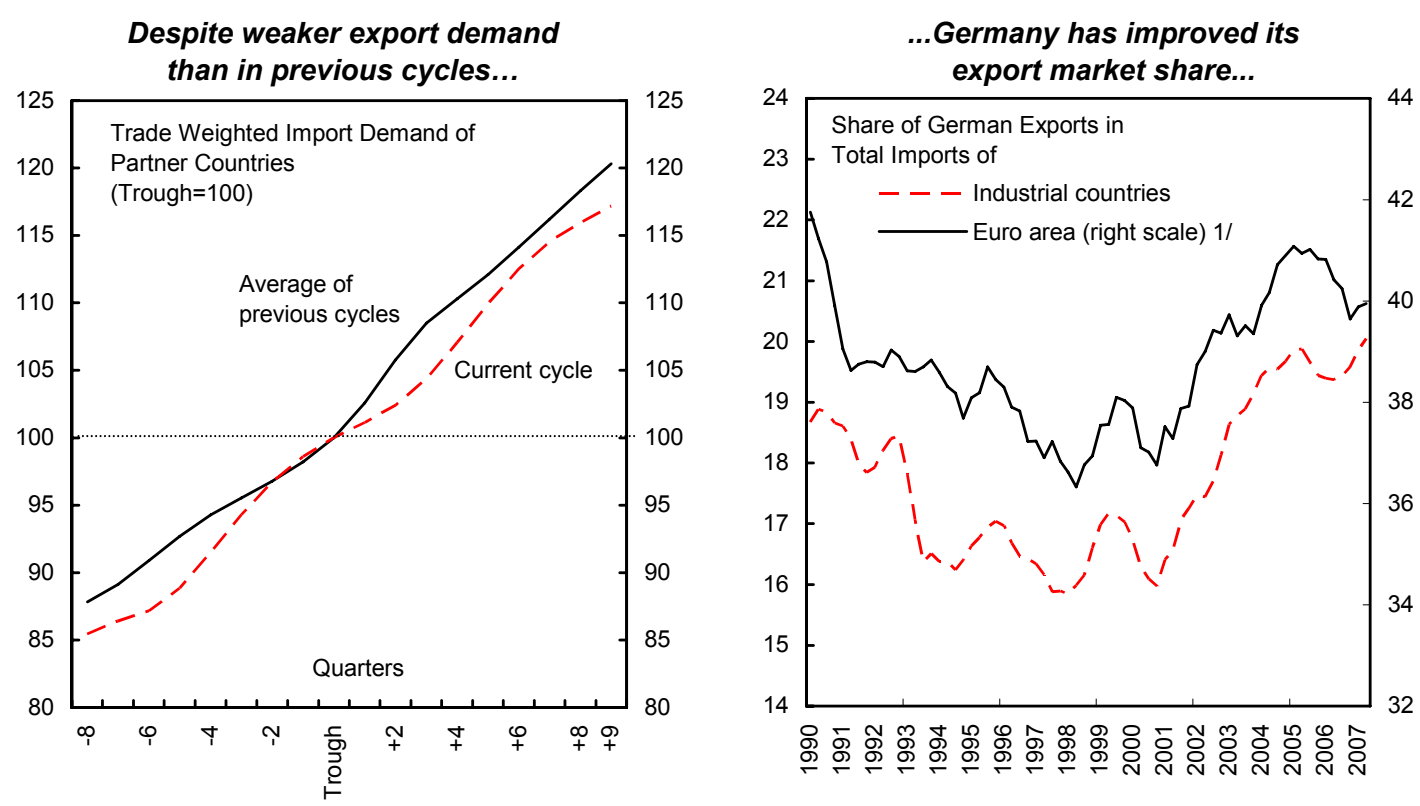

...helped by improved price competitiveness....

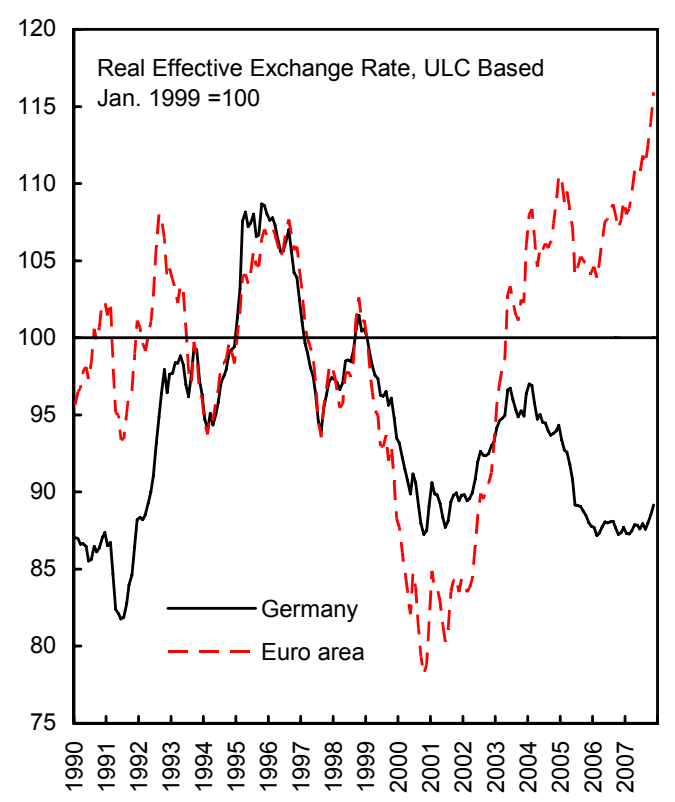

\section{... leading to fast export growth in Europe and new markets.}

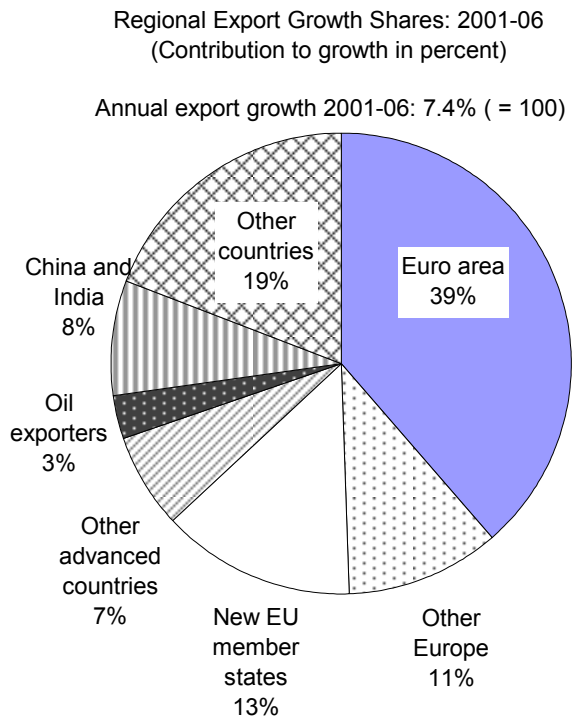

Sources: IFS, WEO, OECD, Direction of Trade Statistics, and IMF staff calculations. 1/ Excludes Belgium and Luxembourg. 
Figure 2. Germany: Corporate Profitability Trends 1/
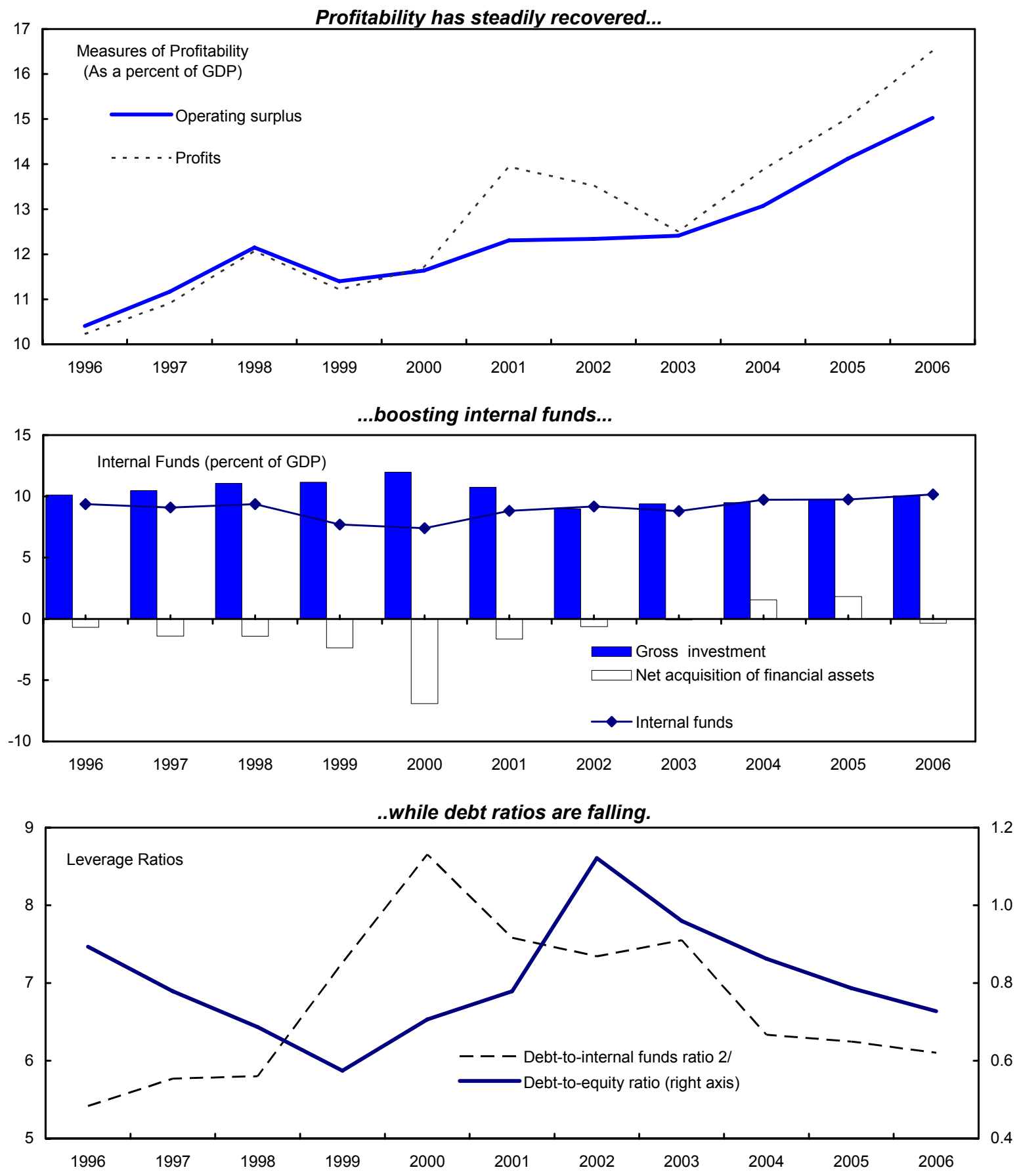

Source: Bundesbank

$1 /$ Nonfinancial corporate sector.

2/ Debt over depreciation plus corporate savings and transfers. 
Figure 3. Germany: Labor Market Developments

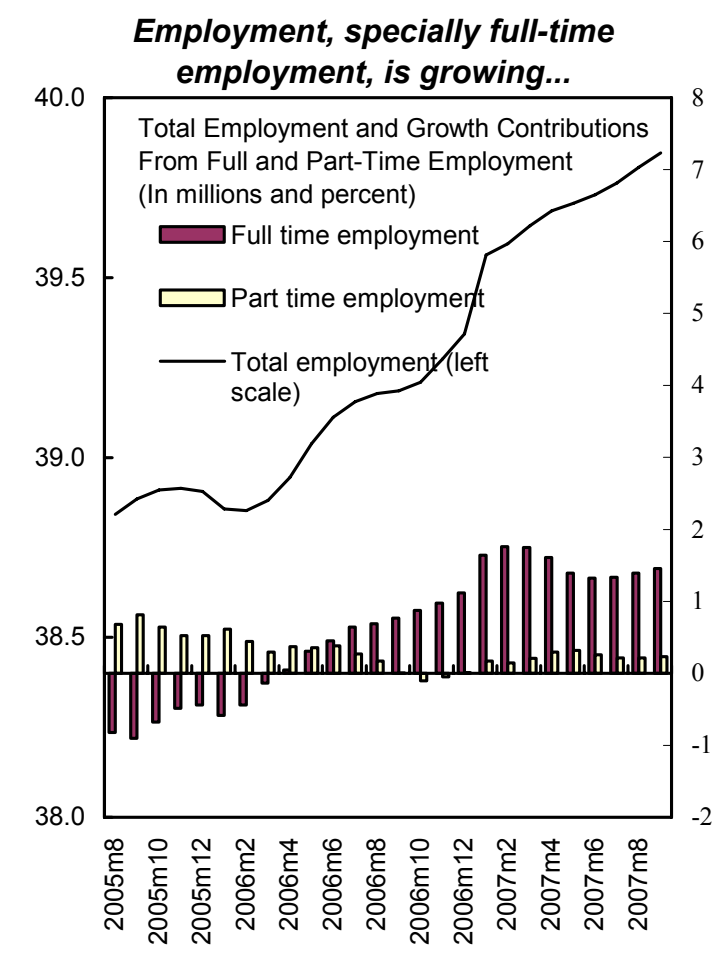

... leading to lower unemployment.

However, labor markets are
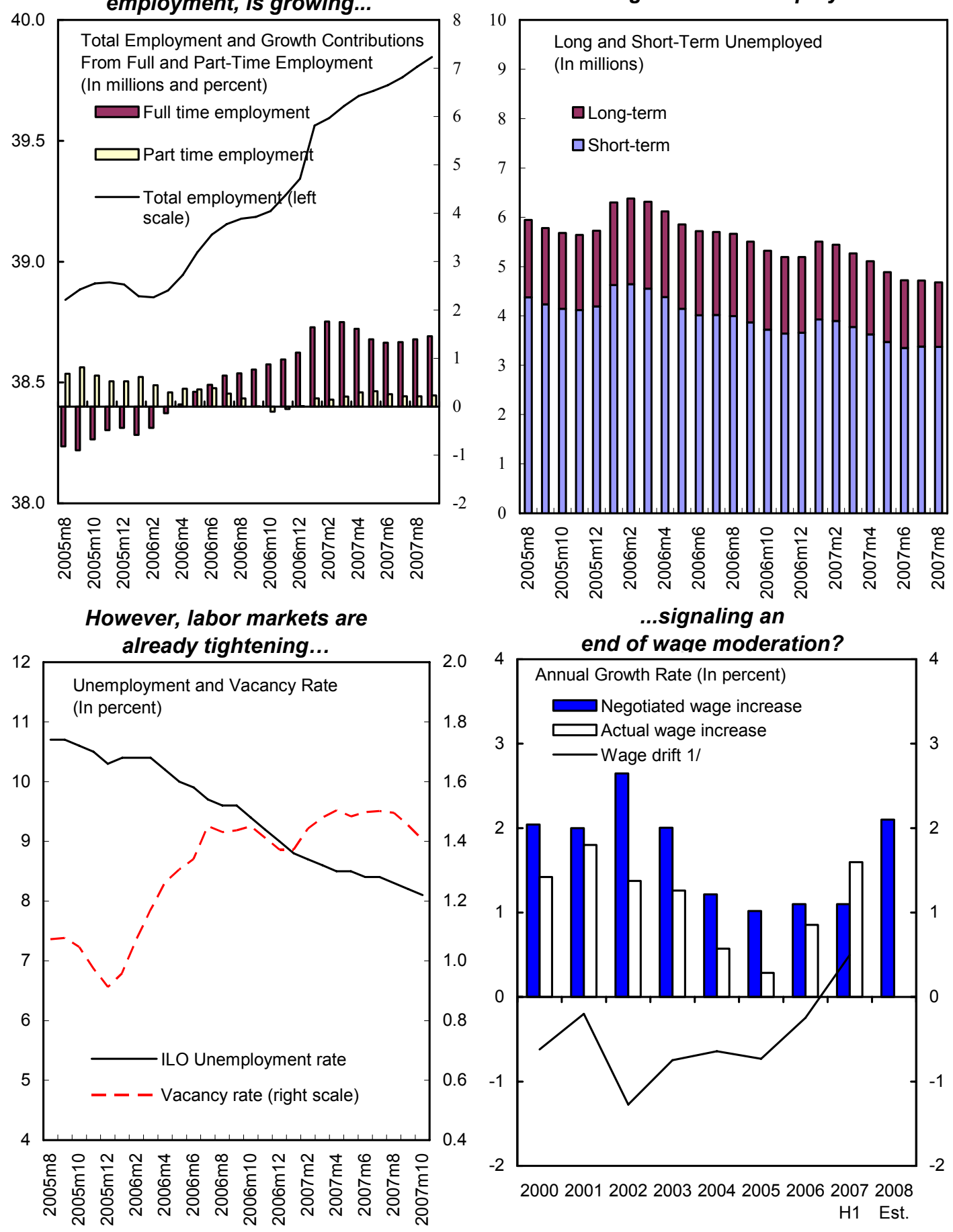

...signaling an

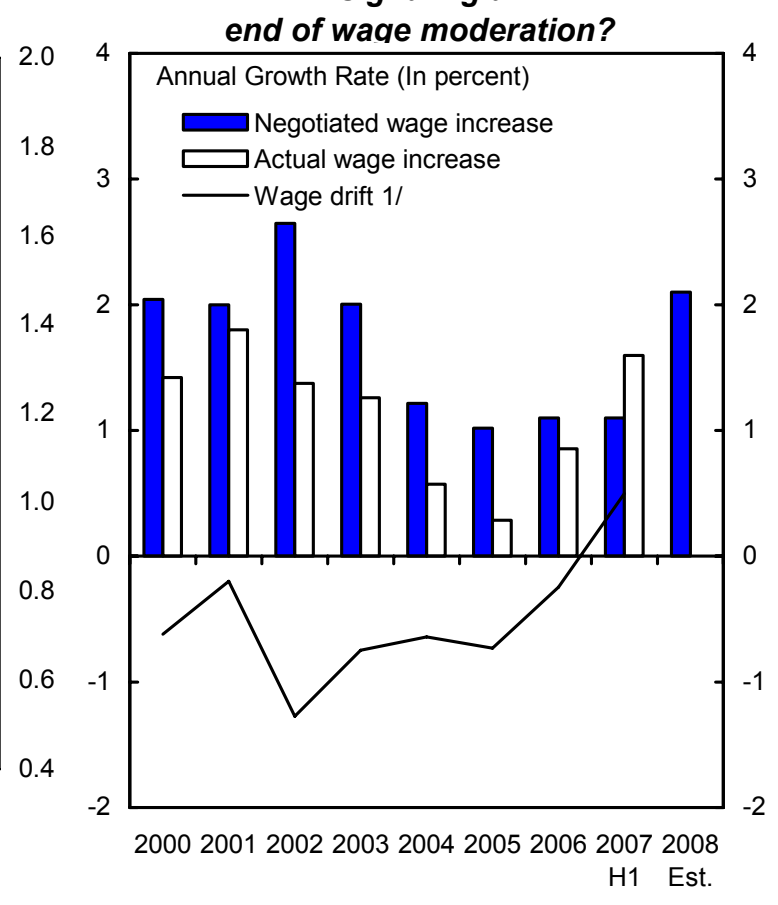

Source: Federal Statistical Office, Federal Labor Office, and Bundesbank $1 /$ Difference between actual and negotiated wage rate. 
Figure 4. Germany: Financial Indicators
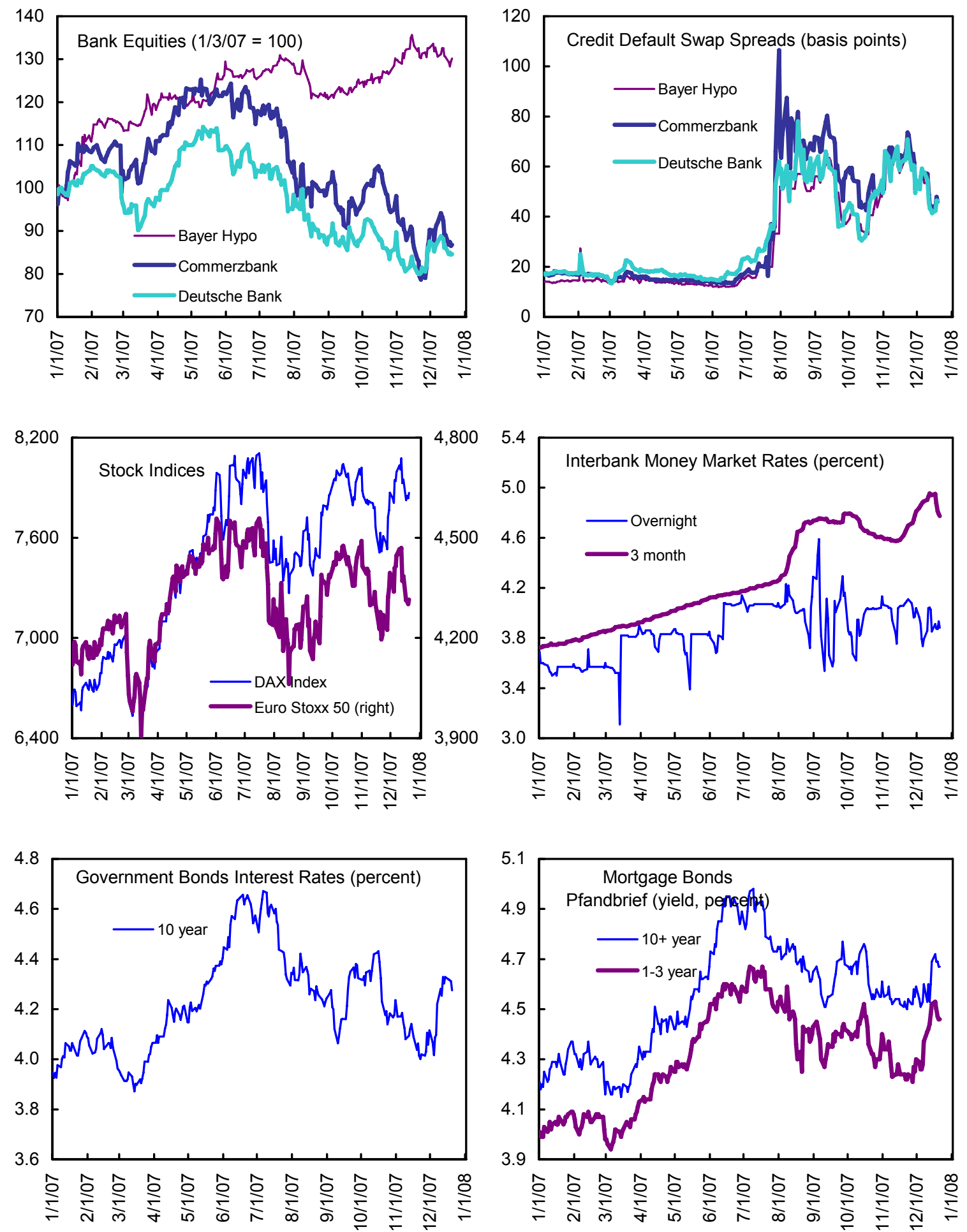

Source: Thomson Financial/DataStream. 
Figure 5. Germany: Corporate Spreads, Money Market Rates, and Lending Standards
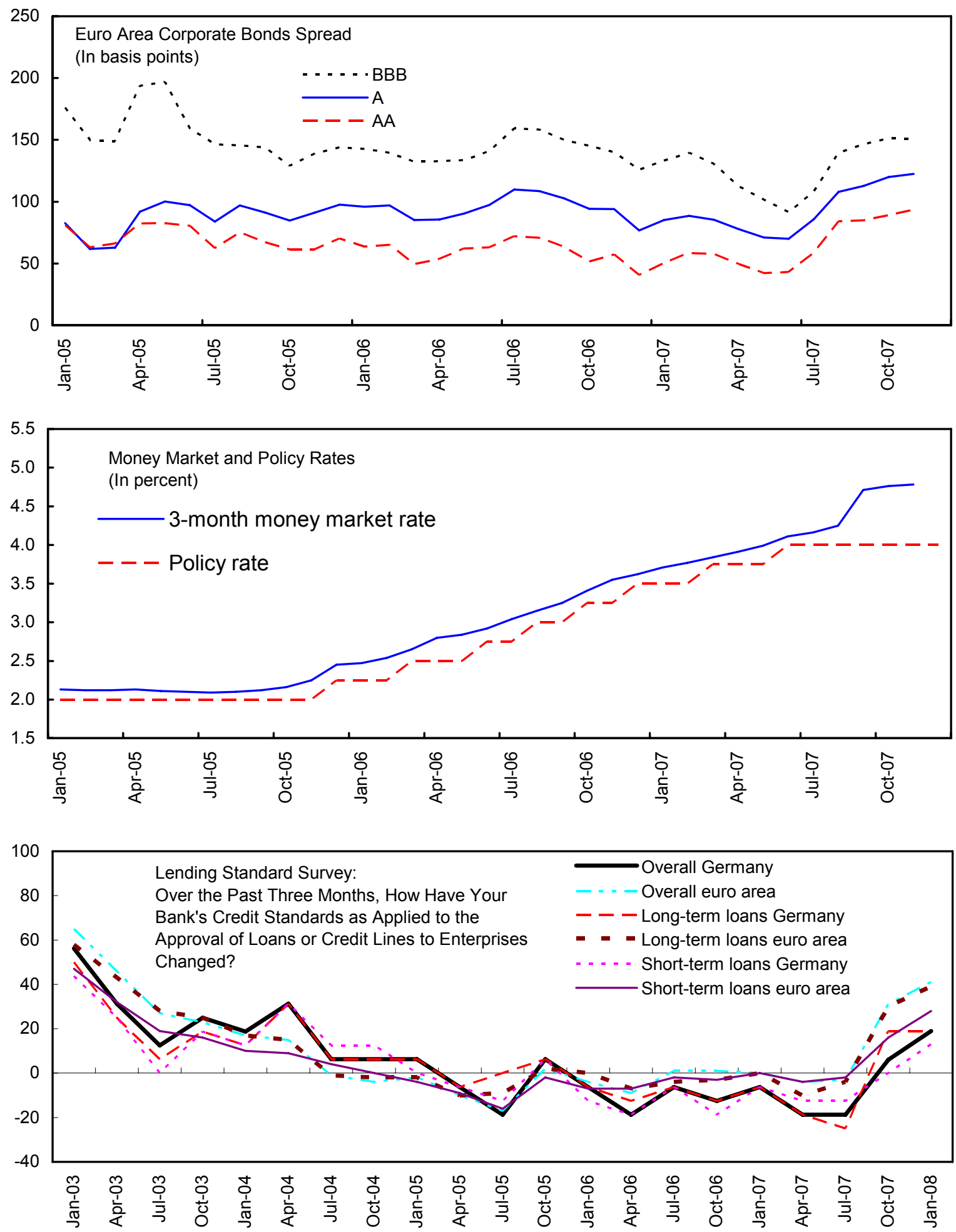

Source: DataStream and Deutsche Bundesbank. 
Figure 6. Germany: Sentiment, Orders, and Production

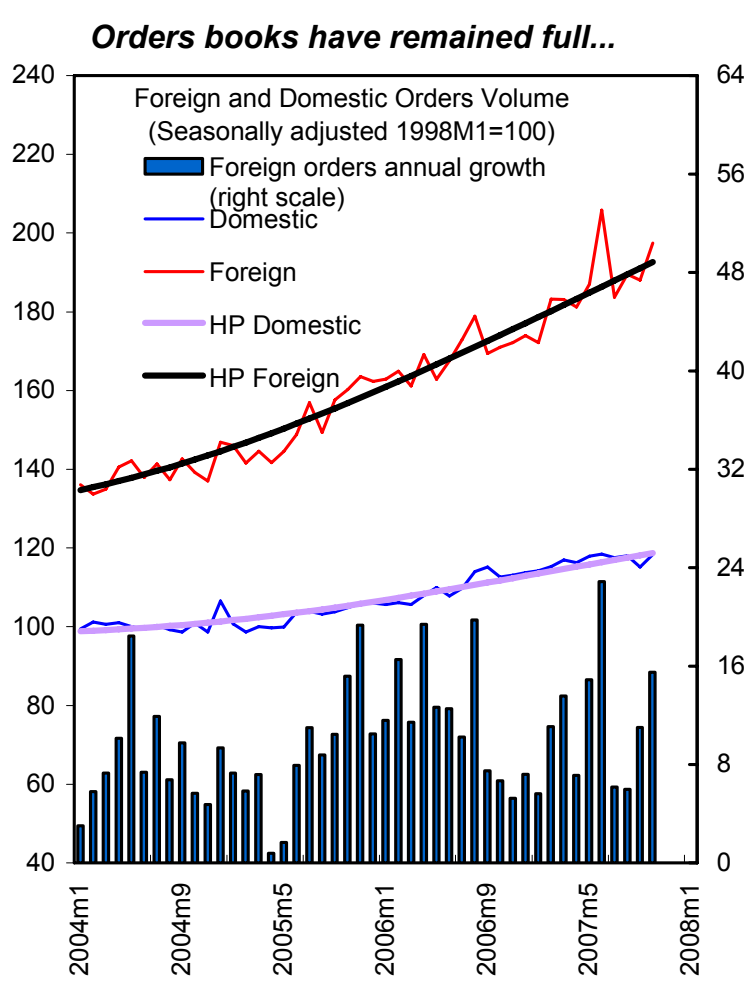

Business expectations are tapering off...
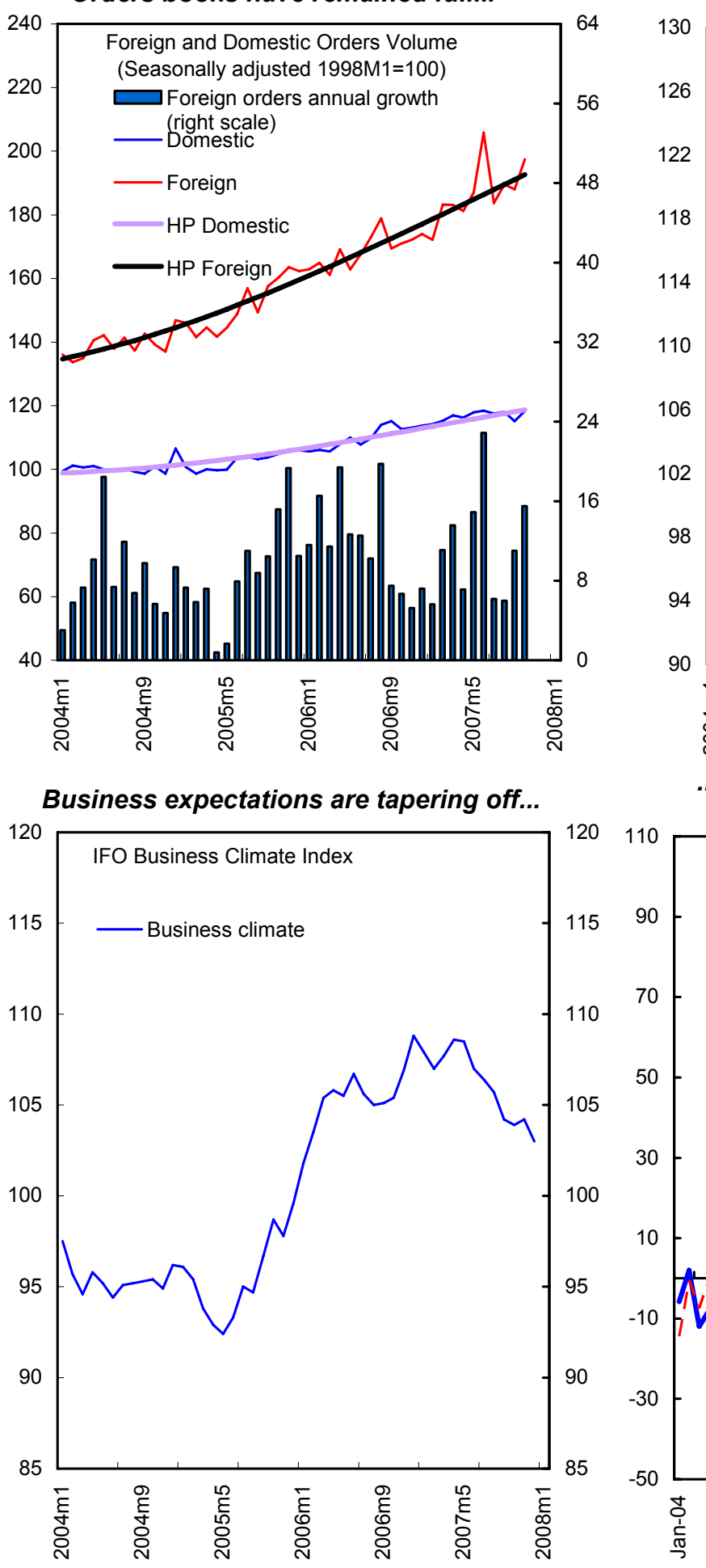

...but industrial production is expanding

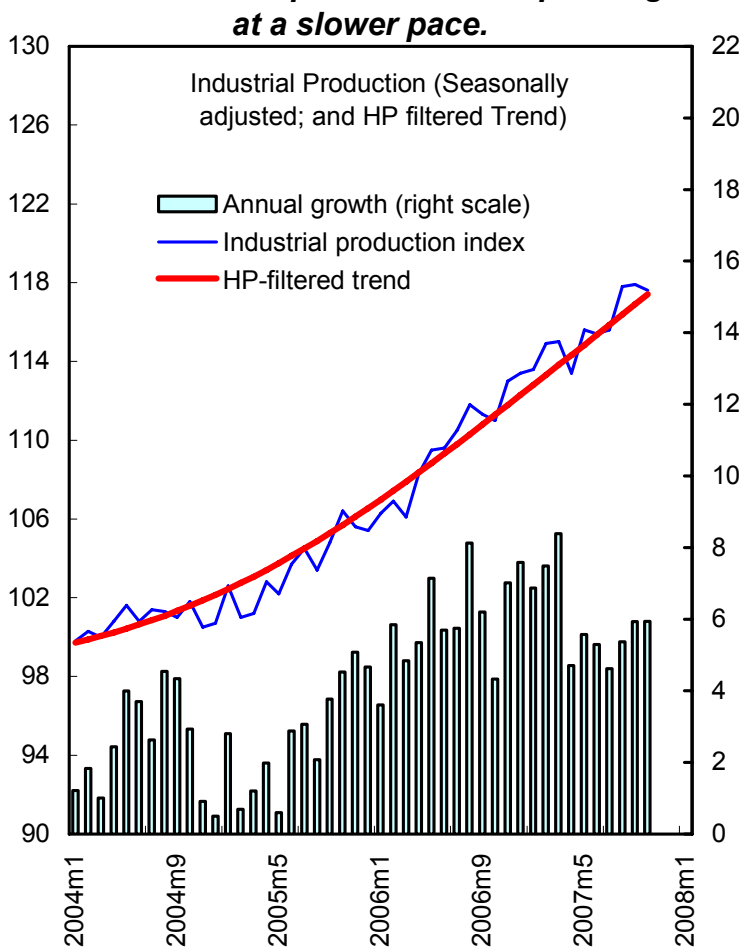

...while consumers are reassessing

120

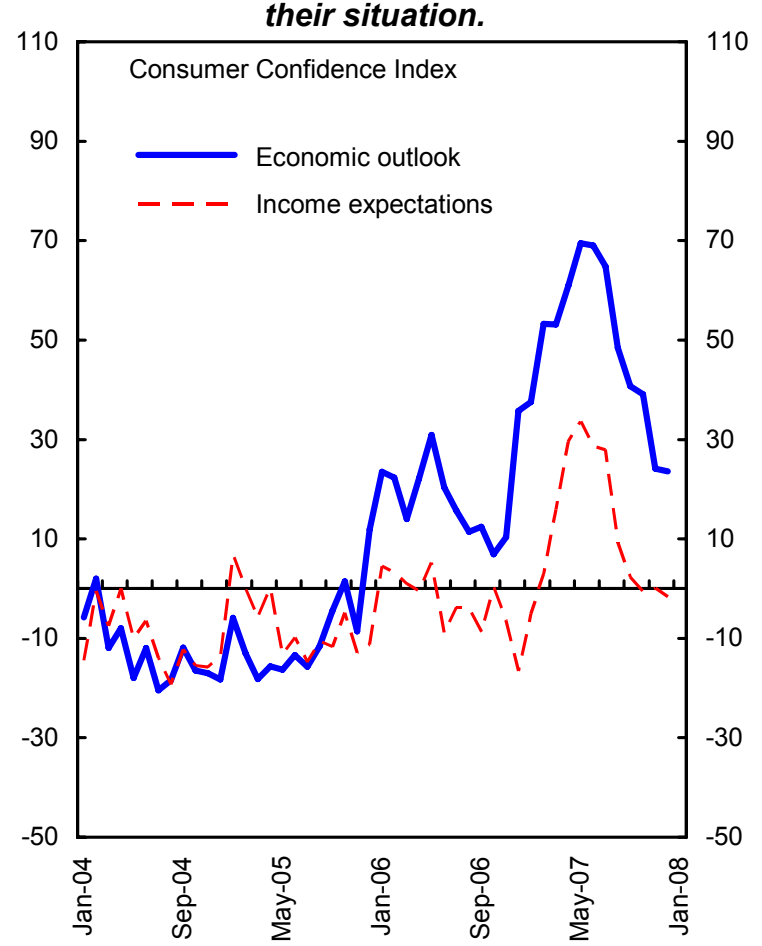

Source: Bundesbank, IFO institute, and GfK. 
Figure 7. Germany: Comparison of Business Cycles, 1990-2007 1/

GDP growth is similar to that in previous cycles.

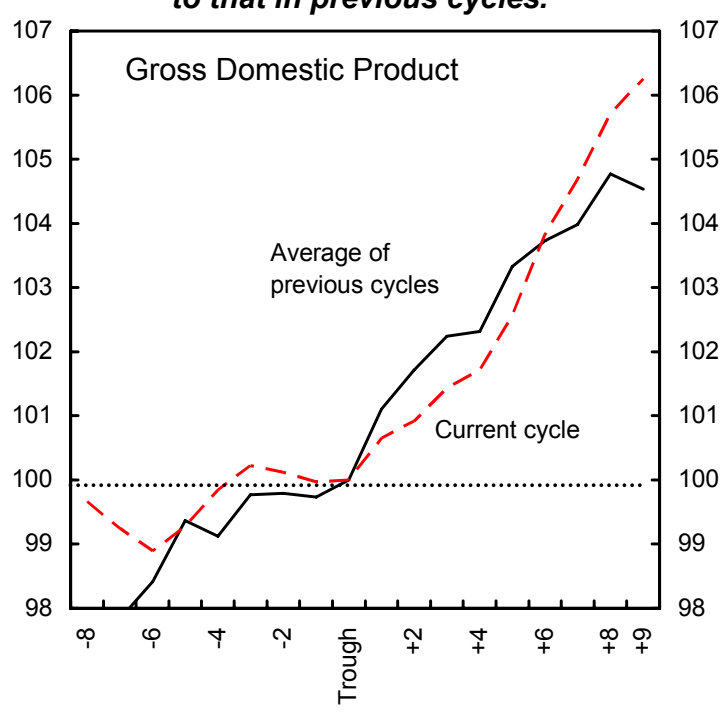

Quarters

...has been accompanied by weak consumption growth...

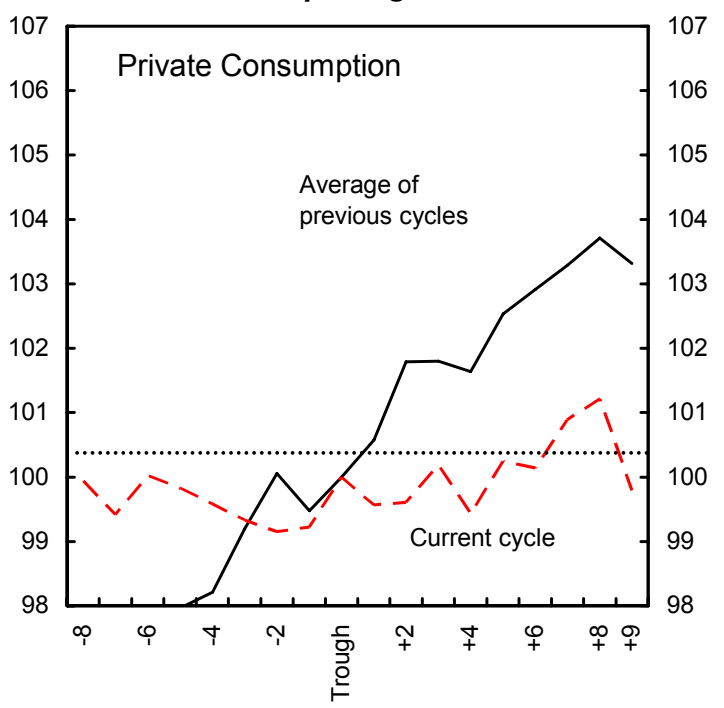

Quarters

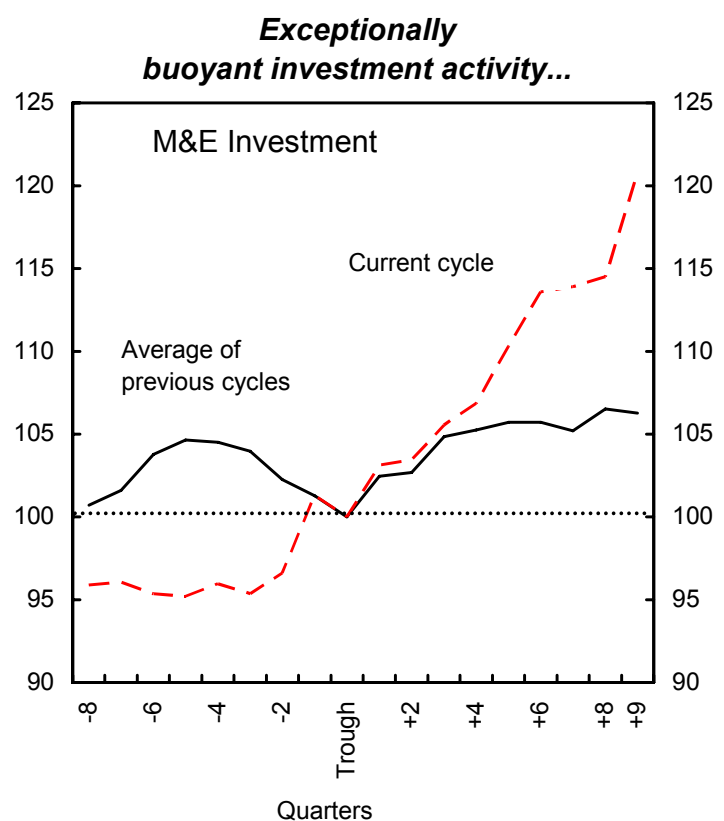

...possibly because of a late recovery in employment growth.

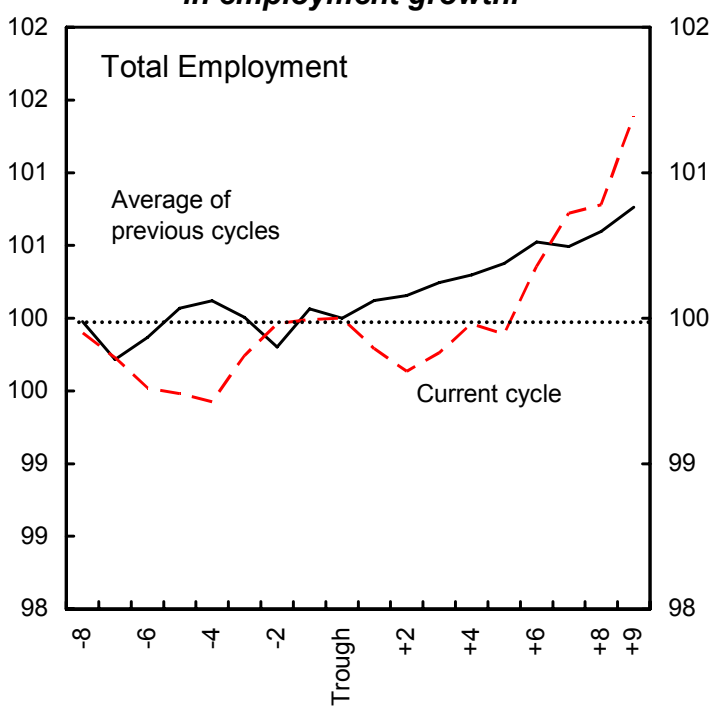

Quarters

Sources: Federal Statistical Office; and IMF staff calculations.

$1 /$ All values relative to trough equal to 100. The trough of the current cycle is Q4 2004. Average of previous cycles is an unweighted average of cycles with troughs in 1993Q2, 1996Q1, and 1989Q4. Troughs identified using largest negative distances between real GDP and trend GDP (HP filter). 
Figure 8. Germany: Labor Productivity Growth, Contributions From TFP, and Capital Deepening

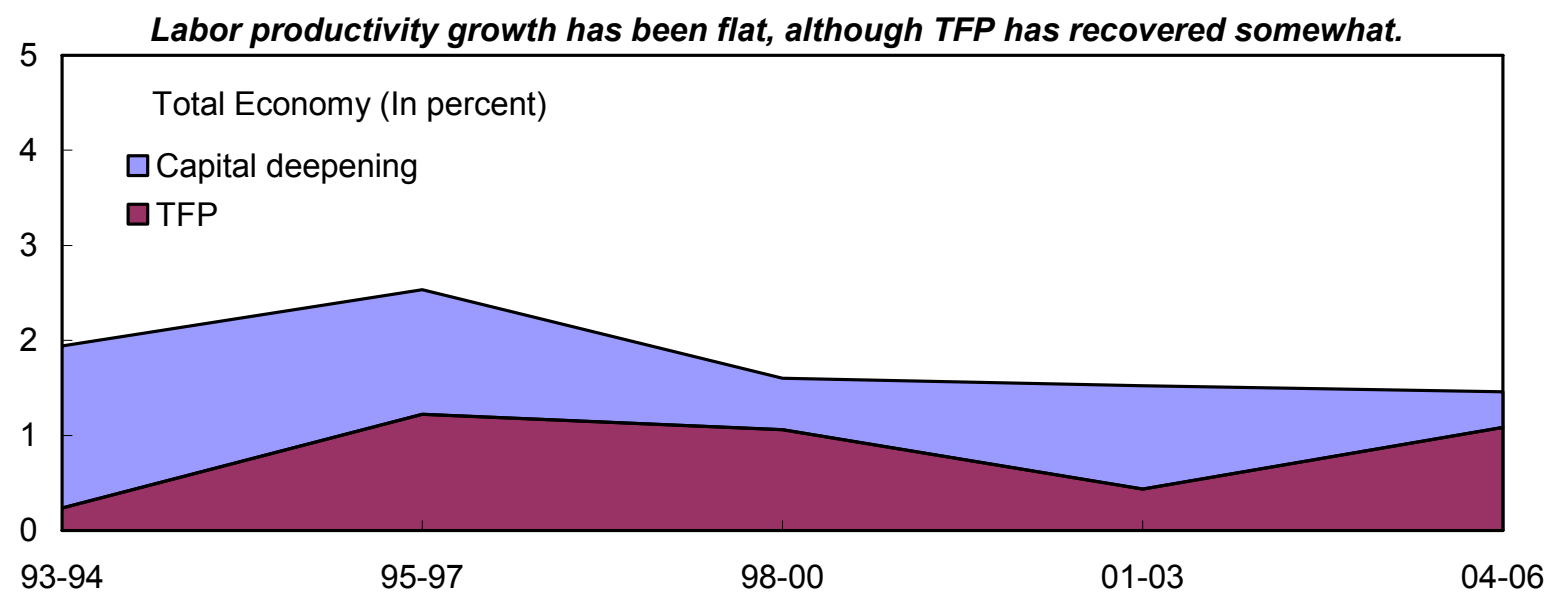

...masking a bifurcation between industry and services...
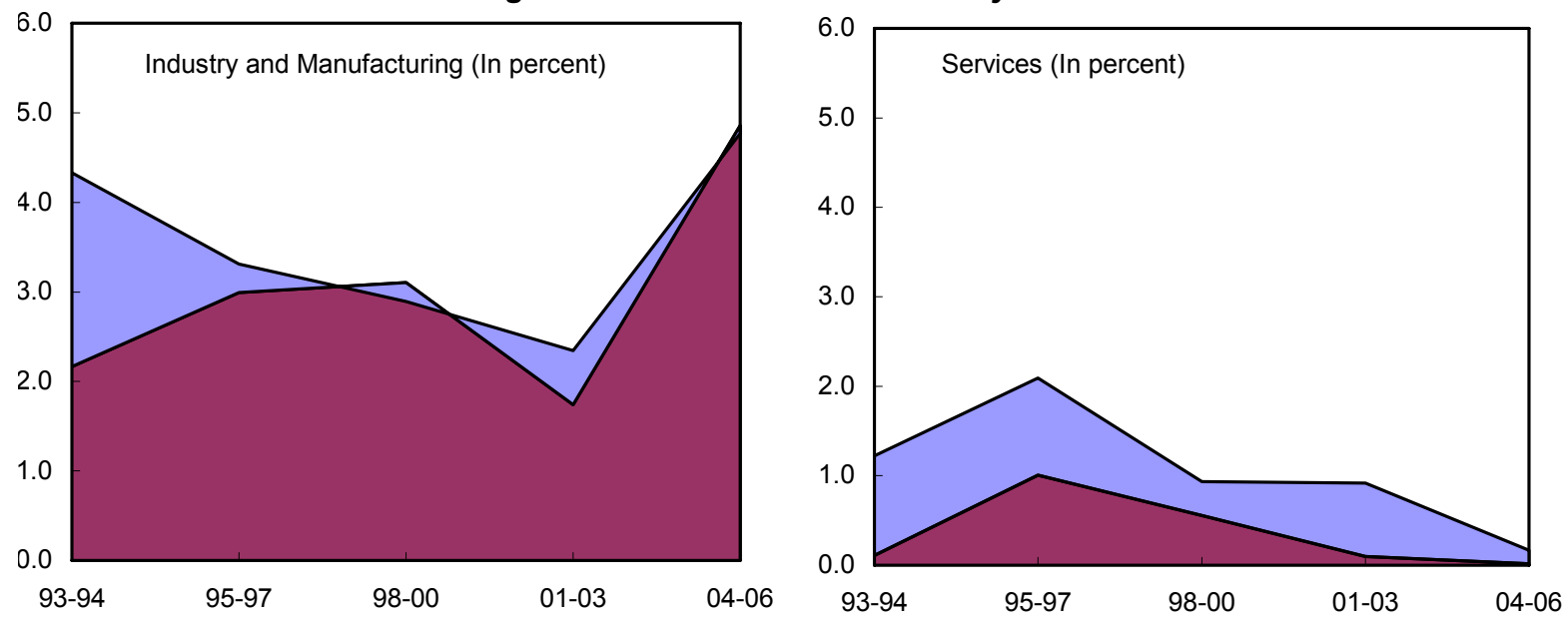

...although cyclical hiring in services may overplay low productivity growth in services.

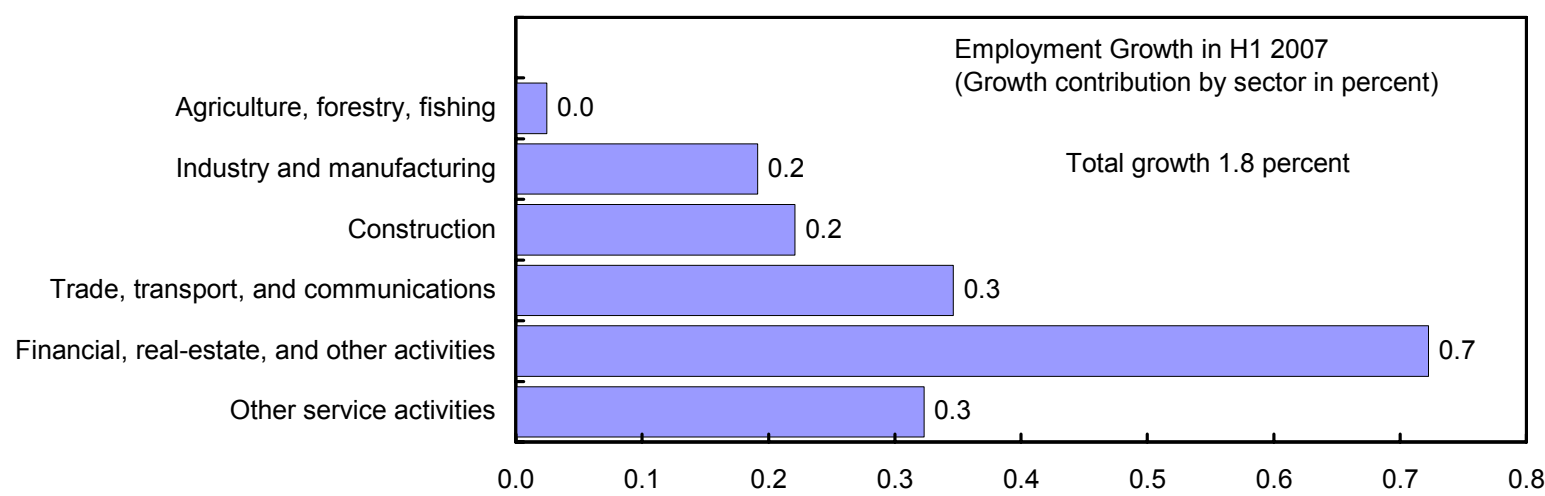

Source: Federal Statistical Office and staff calculations. 
Figure 9. Selected Countries: Patent Developments

German residents have many patentable ideas...

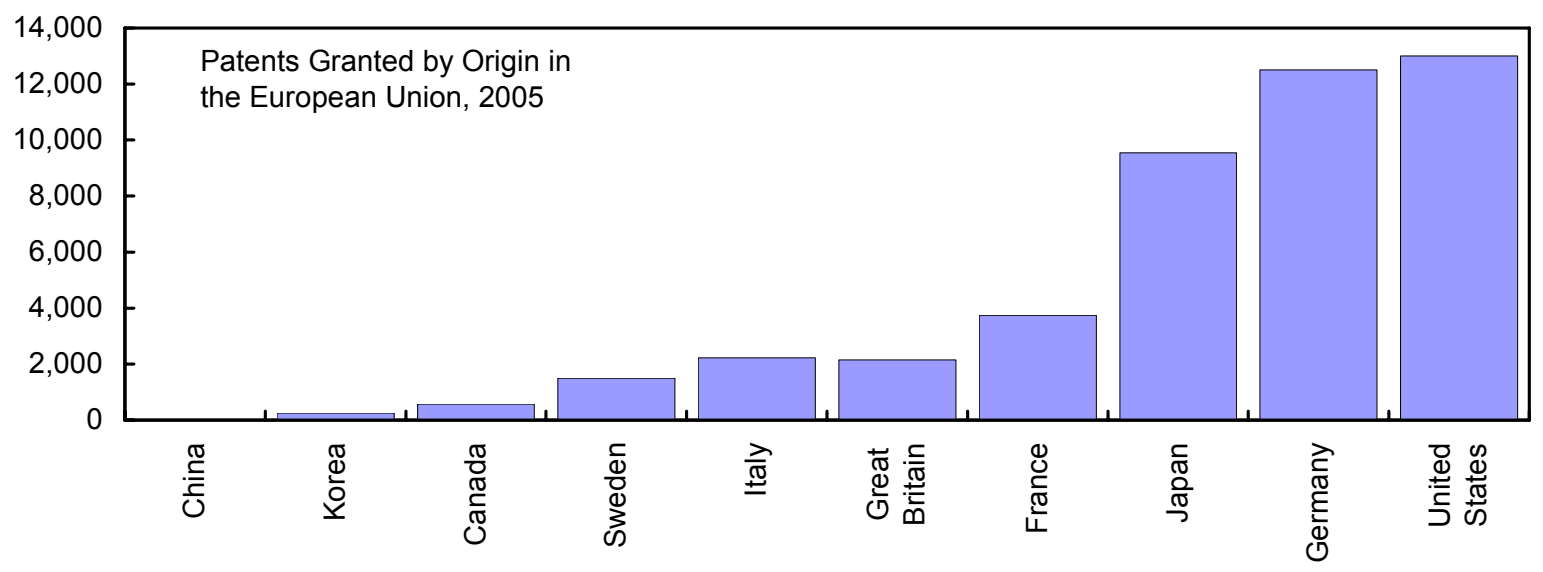

...which is especially evident in per capita terms.

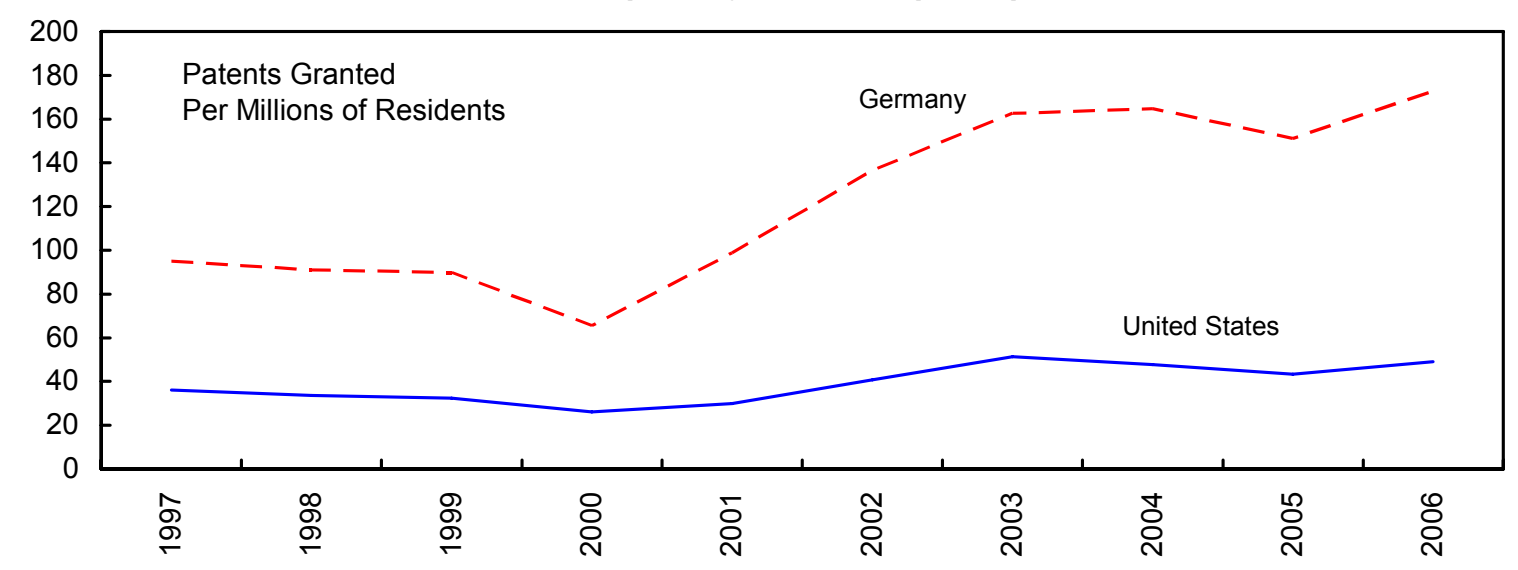

They tend to be strong in traditional mechanical and chemical engineering areas.

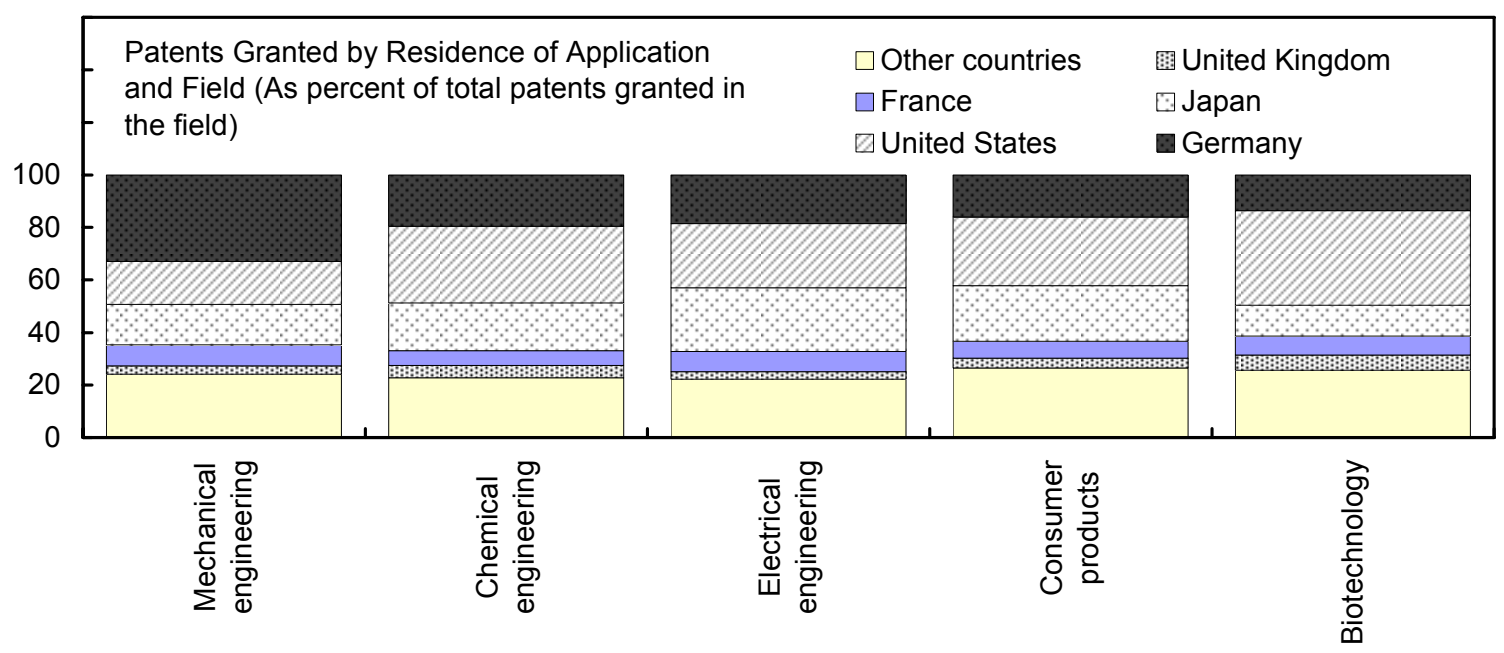

Sources: European Patent Office; OECD; and IMF staff calculations. 
Figure 10. Germany: Labor Market and Migration Trends

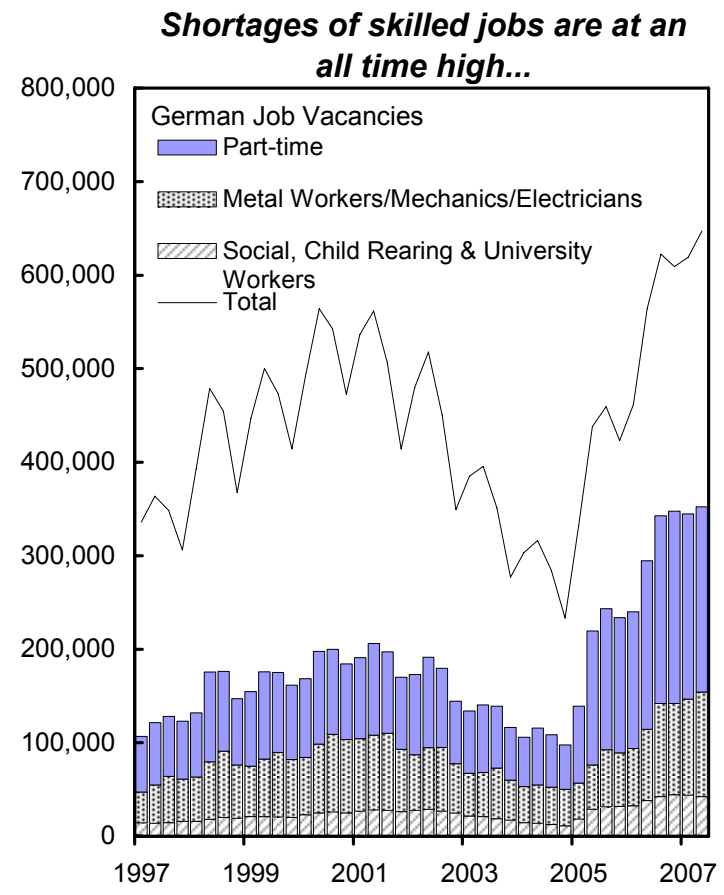

...to countries that target high skilled labor..

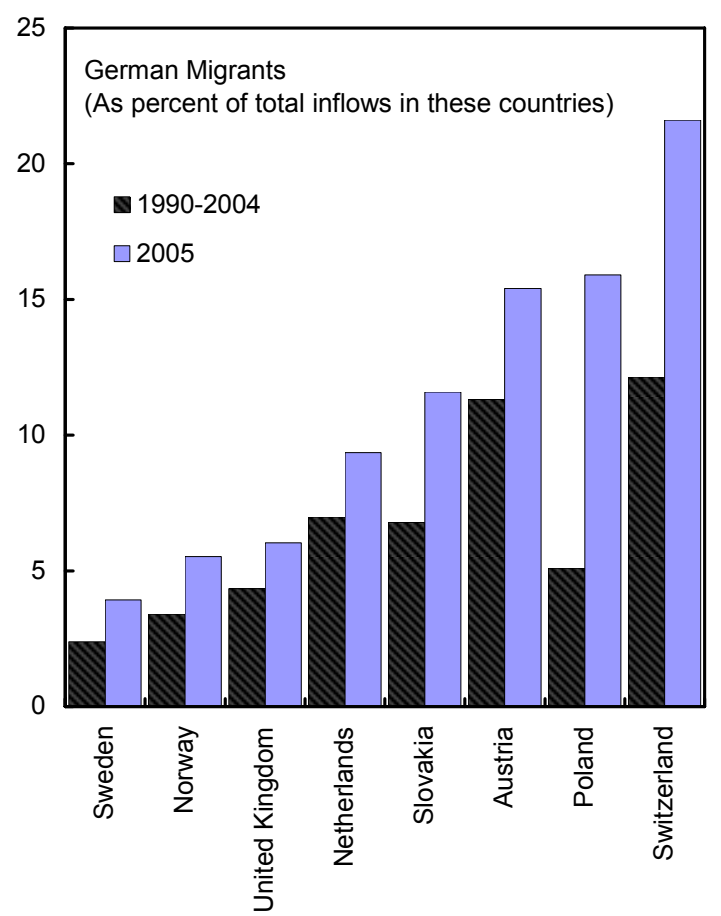

...as Germans leave...

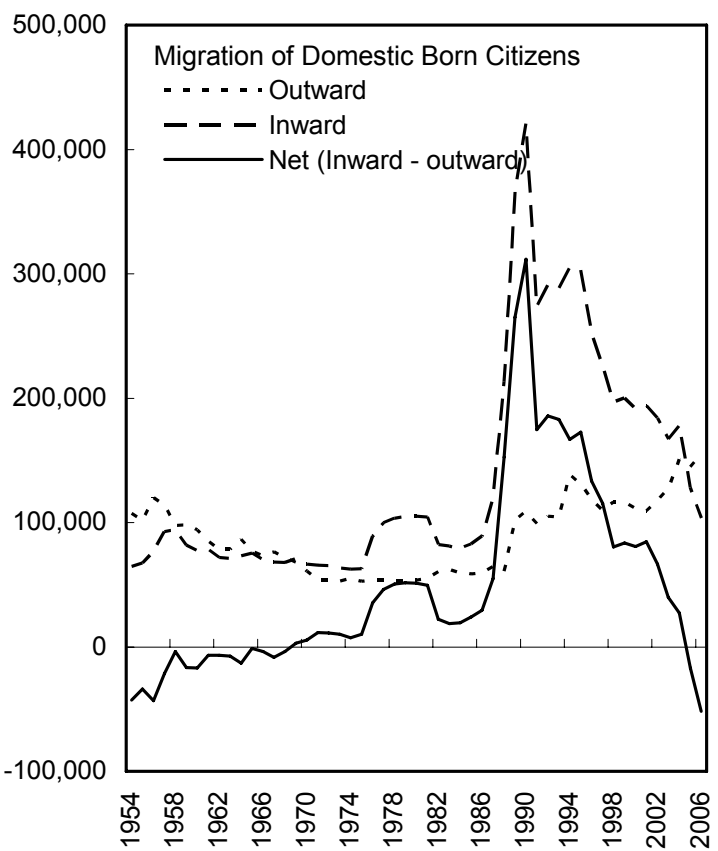

... and foreigners go somewhere else.

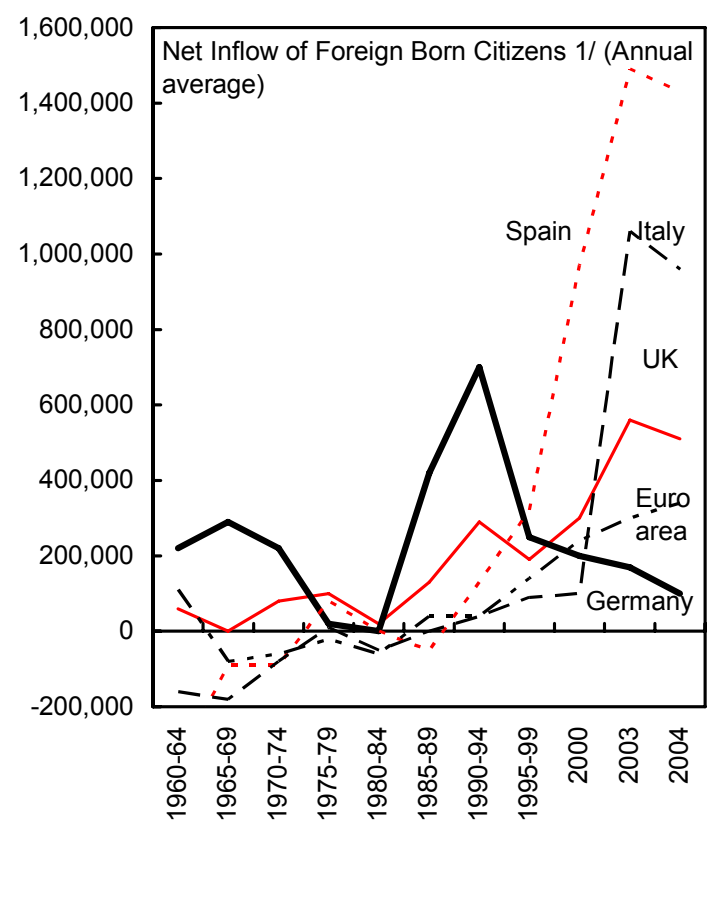

Source: Federal Statistical Office; and IMF staff calculations. 1 / Inward migration less outward migration of foreigners. 
Figure 11. Selected Countries: Traditional Bank Financing

The banking system continues to be fragmented...
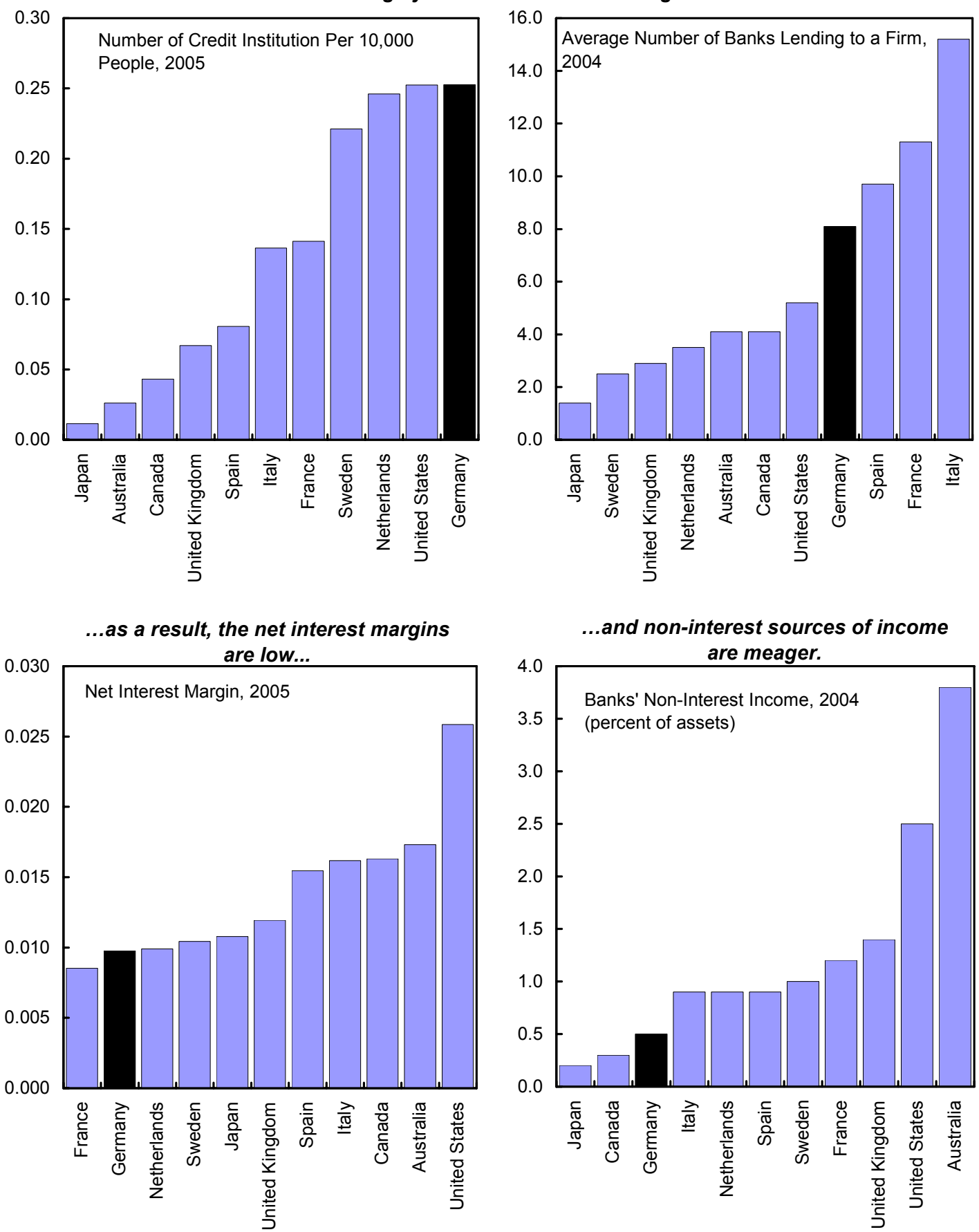

Sources: World Economic Outlook 2006; Financial Sector Development Indicators; and IMF staff calculations. 
Figure 12. Selected Countries: Capital Markets in Comparative Perspective
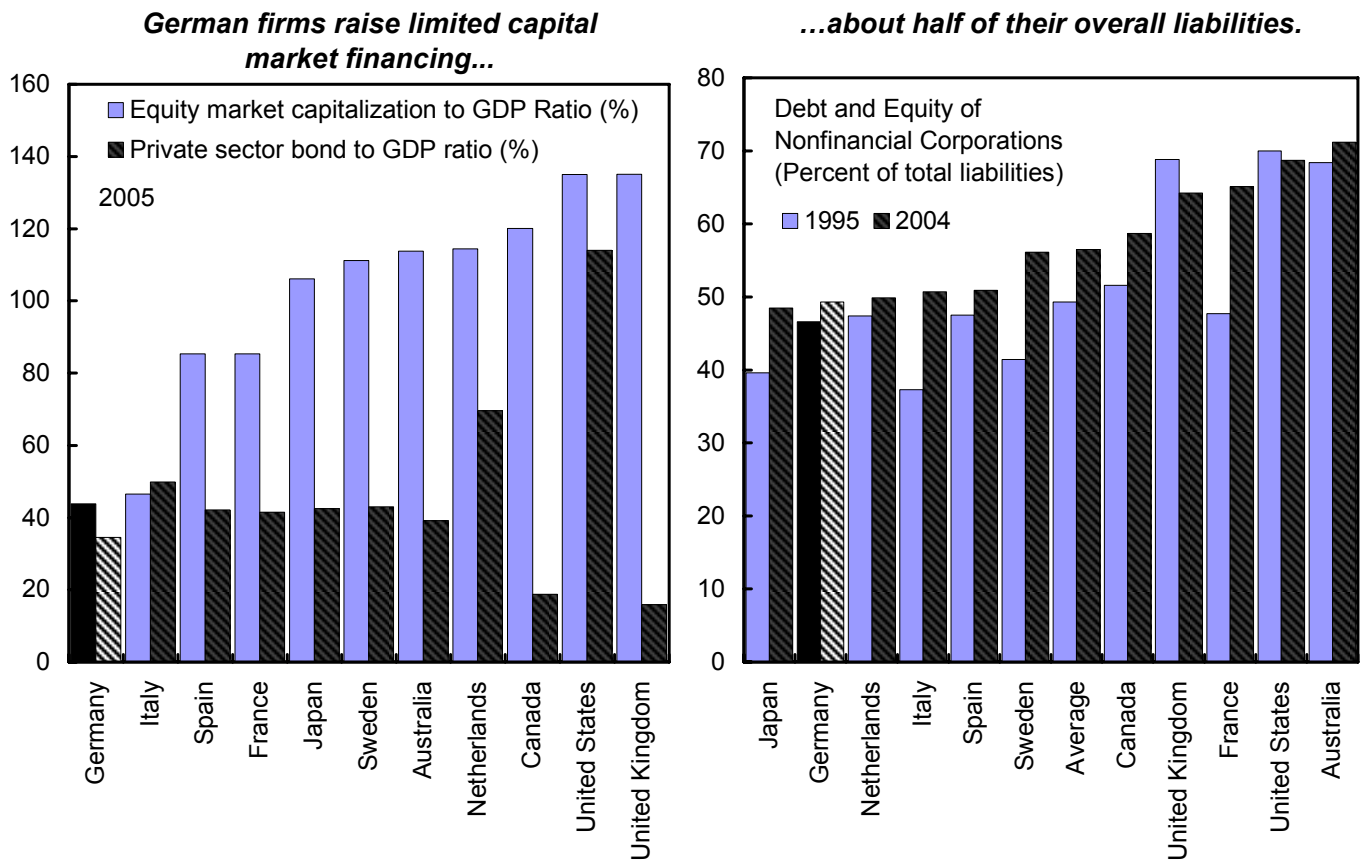

But market financing is increasing...

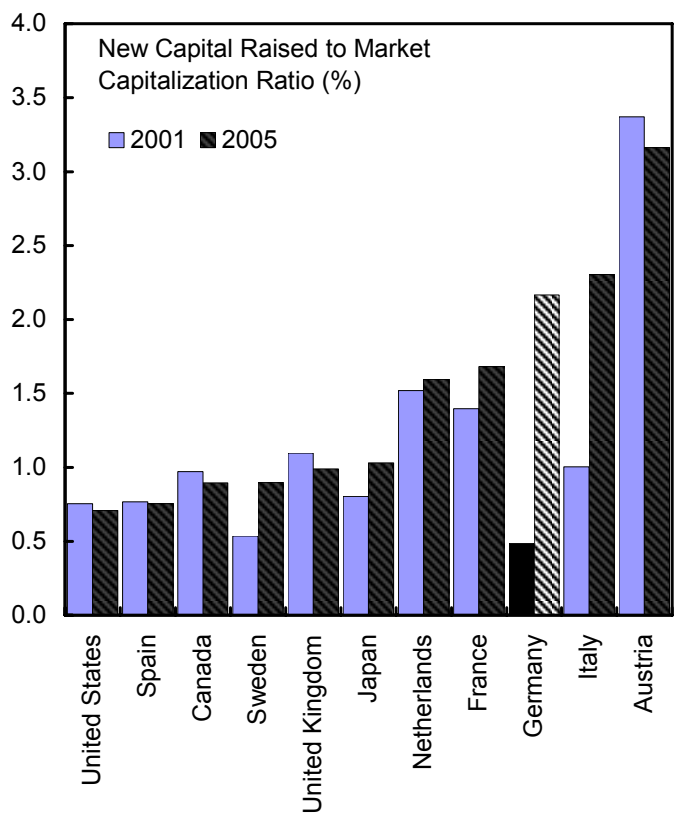

...raising equity market liquidity.

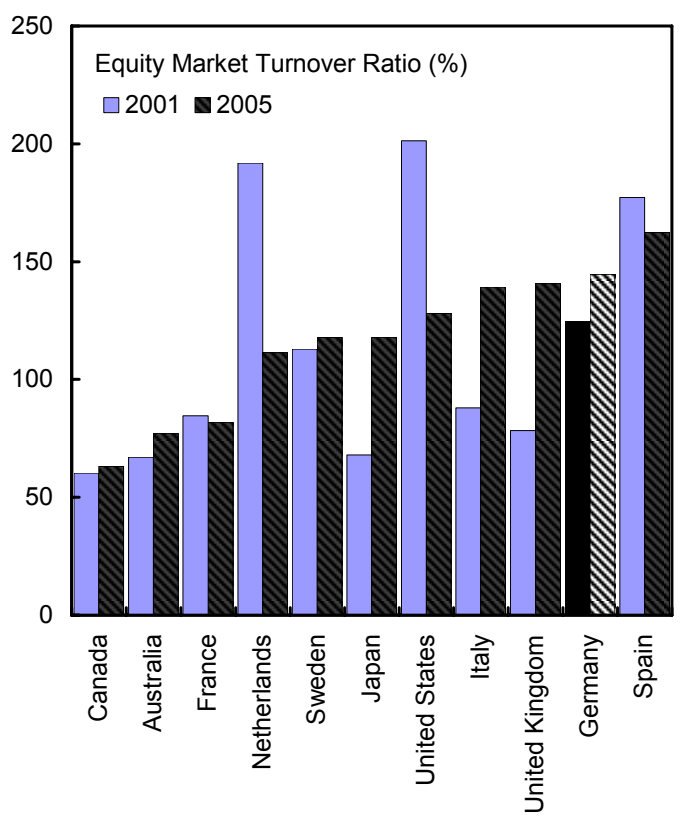

Sources: World Economic Outlook 2006; and Financial Sector Development Indicators. 
Figure 13. Selected Countries: Equity Market Efficiency
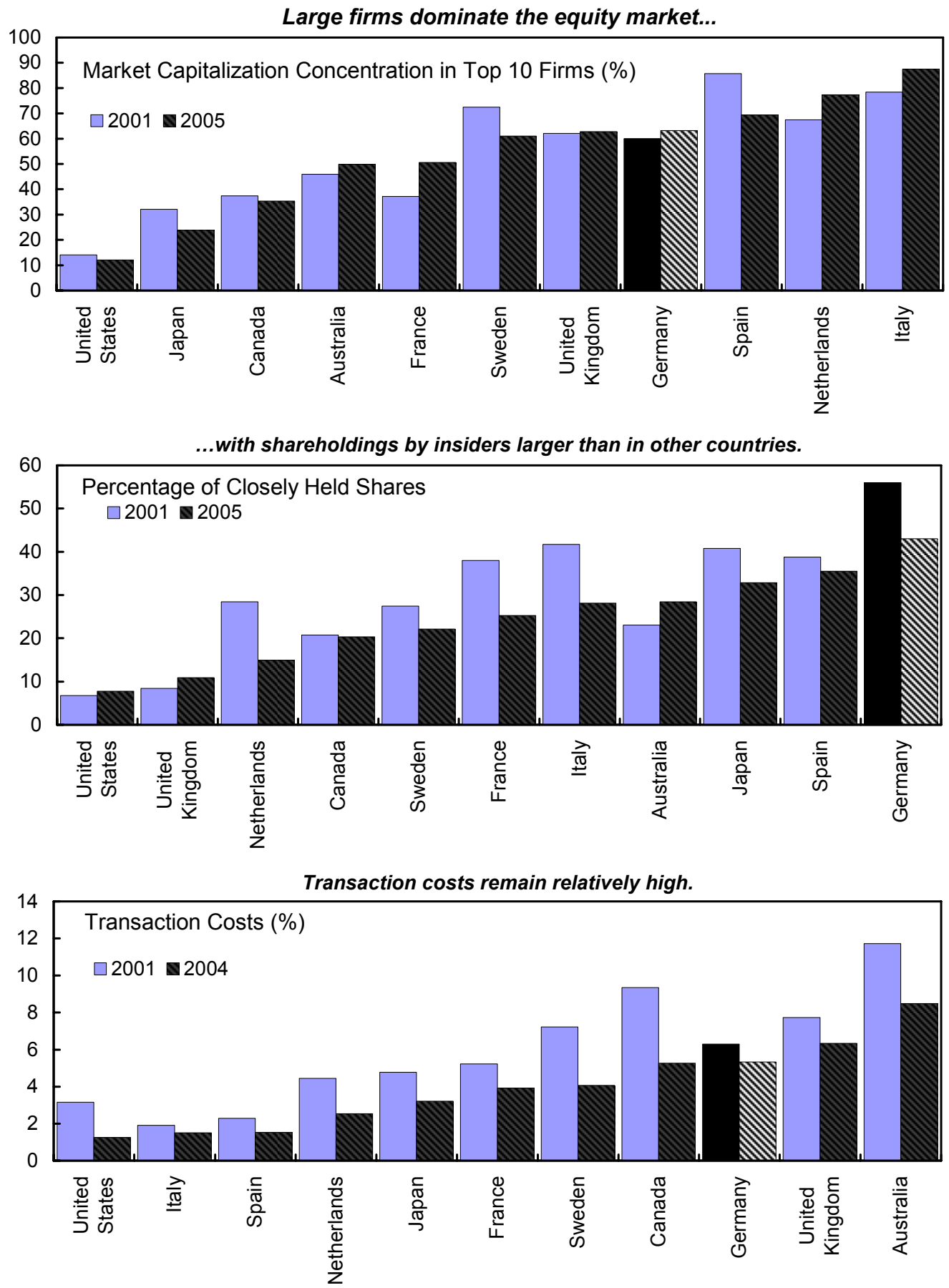

Source: Financial Sector Development Indicators; and IMF staff calculations. 
Figure 14. Selected Countries: Nontraditional Financing

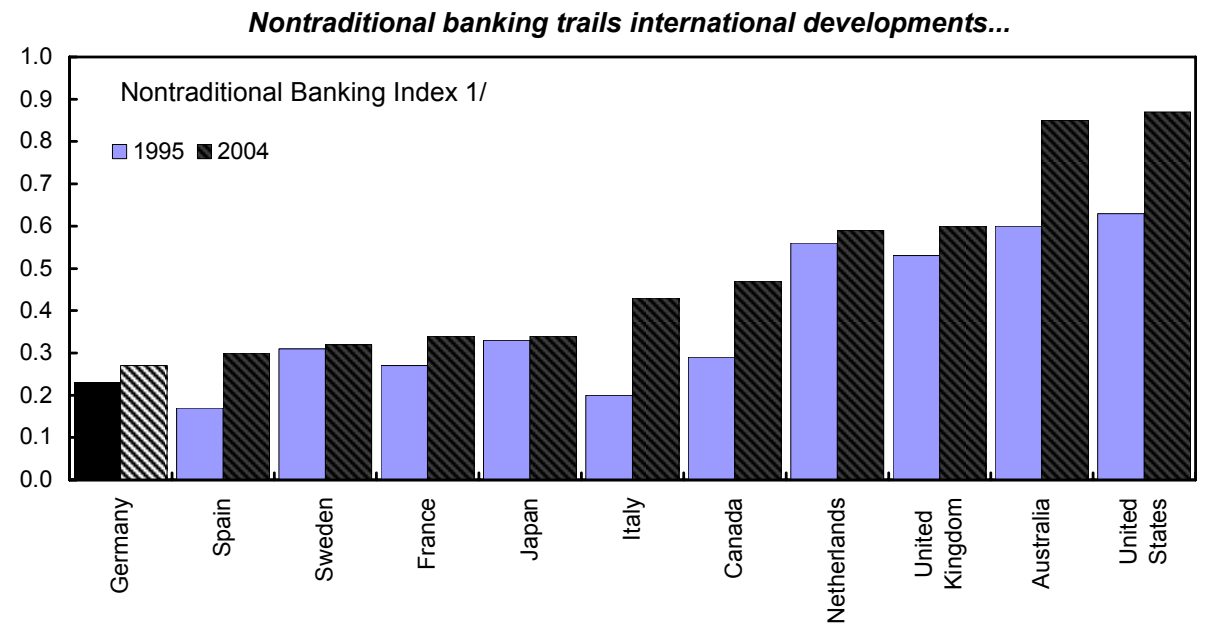

...as does nonbank intermediation...

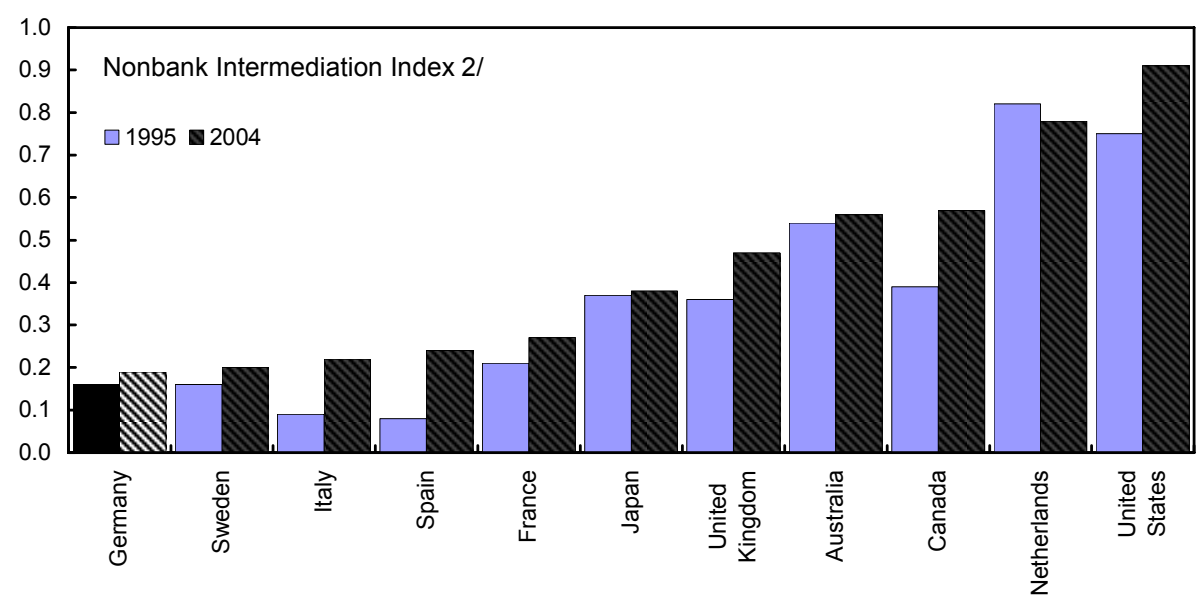

...although households are beginning to rely on nonbanks.

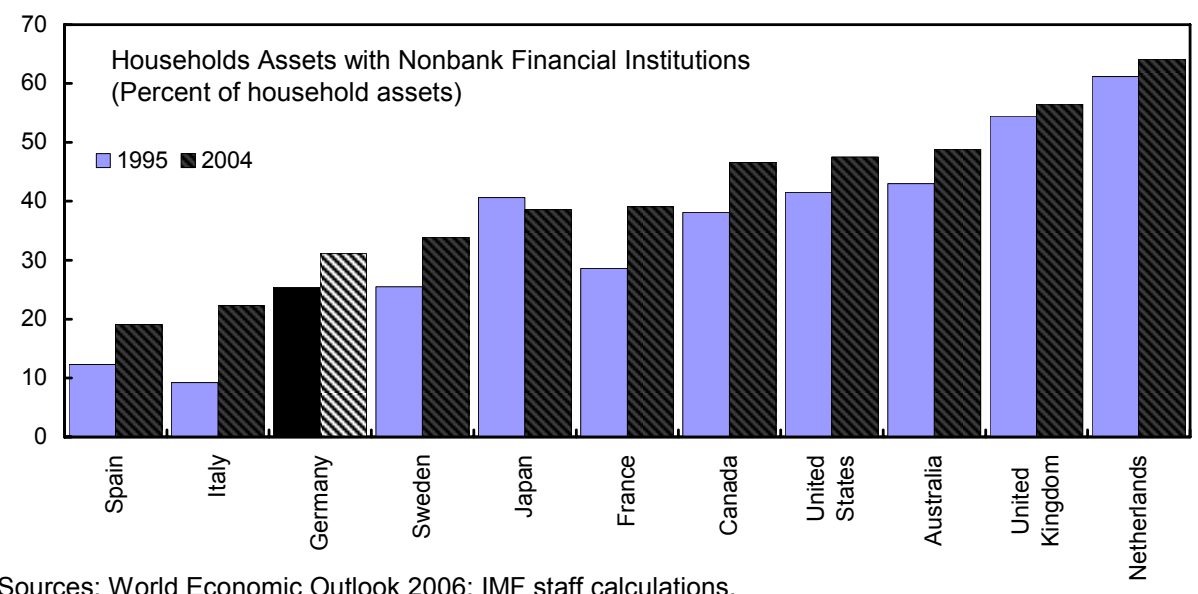

Sources: World Economic Outlook 2006; IMF staff calculations.

$1 /$ Measures the evolution of banks into new area of financial intermediation. The components of this index are: bank noninterest income, bank liabilities vis-à-vis nonbank financial institutions, and bank assets with nonbank financial institutions.

2/ Measures the relevance of nonbank financial intermediaries. The components of this index are: household assets with nonbank financial institutions, loans by nonbank financial institutions, and bonds issued by nonbank financial institutions. 
Figure 15. Germany: Healthcare Expenditures and Aging
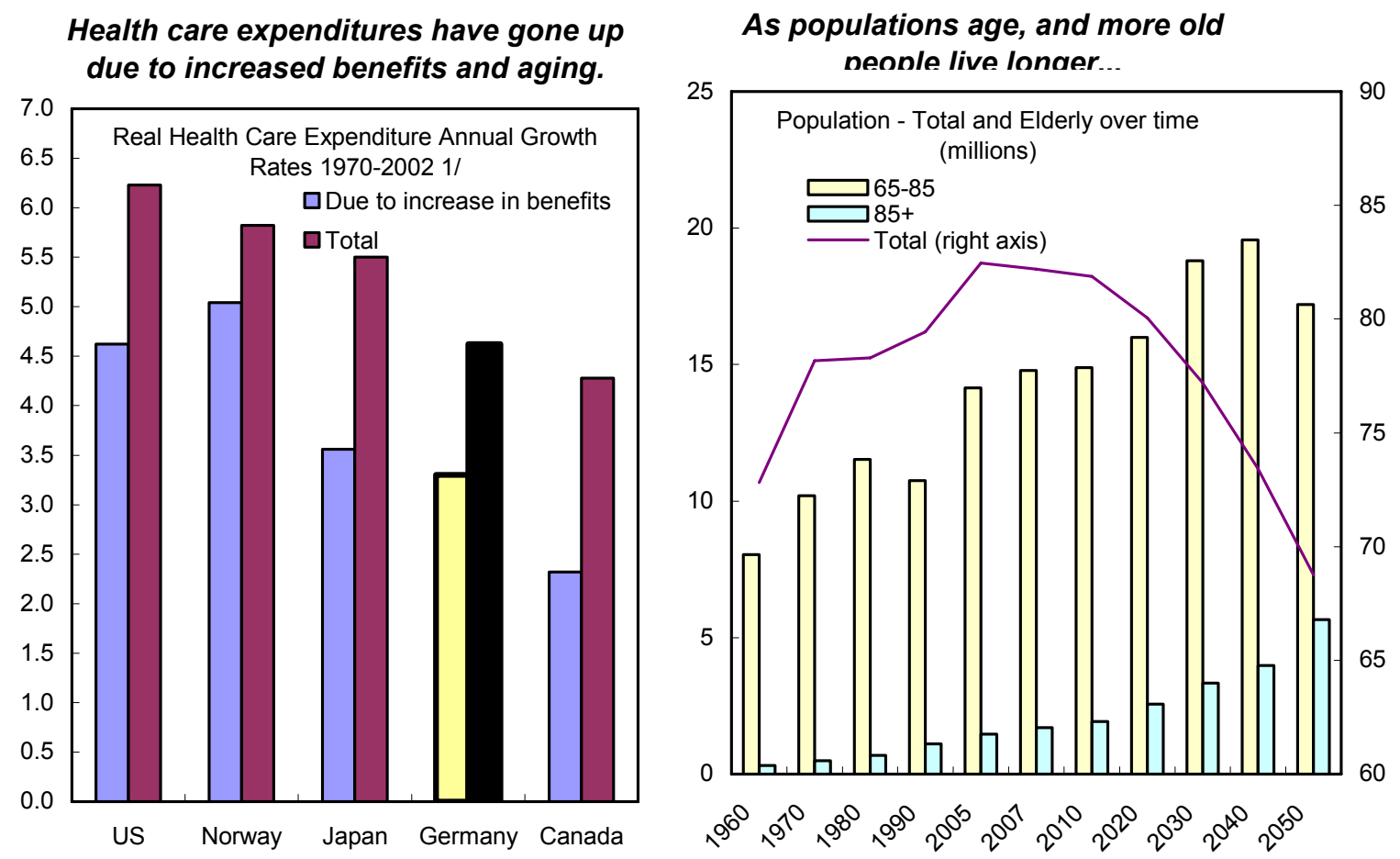

...and with health care expenditures steepening with age...
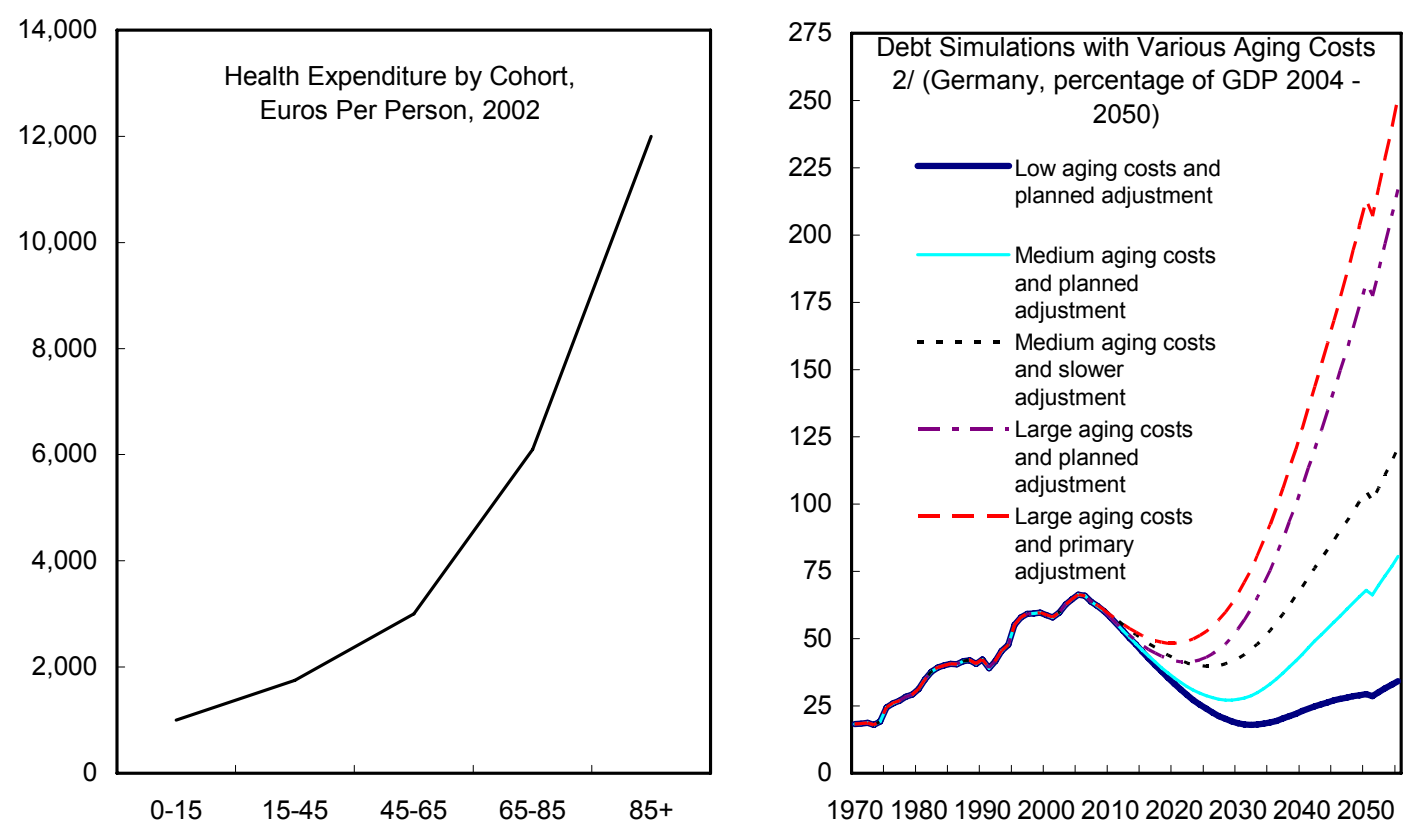

1/ Federal Statistical Office, Hagist, Christian and Laurence Kotlikoff (2005) Who's Going Broke? Comparing Growth and Health Care Costs in Ten OECD countries, NBER Working paper 11833.

2/ For different scenarios descriptions see text table General Government Indicative Balance Sheet for 2007.

Sources: Staff calculations and Hagist and Kotlikoff (2005). 
Table 1. Germany: Basic Data

Total area

357,041 square kilometers

tal population (2005)

82.4 million

GDP per capita (2006)

US\$ 35, 439

\begin{tabular}{|c|c|c|c|c|c|c|c|c|c|}
\hline & 2000 & 2001 & 2002 & 2003 & 2004 & 2005 & \multicolumn{2}{|c|}{$200620071 /$} & $20081 /$ \\
\hline & \multicolumn{9}{|c|}{ (Percentage change) } \\
\hline \multicolumn{10}{|l|}{ Demand and supply } \\
\hline Private consumption & 2.4 & 1.9 & -0.8 & 0.1 & 0.2 & -0.1 & 1.0 & -0.3 & 1.4 \\
\hline Public consumption & 1.4 & 0.5 & 1.5 & 0.4 & -1.5 & 0.5 & 0.9 & 2.0 & 0.9 \\
\hline Gross fixed investment & 3.0 & -3.6 & -6.1 & -0.3 & -0.2 & 1.0 & 6.1 & 5.5 & 1.7 \\
\hline Construction & -2.4 & -4.6 & -5.8 & -1.6 & -3.8 & -3.1 & 4.3 & 2.8 & 0.7 \\
\hline Machinery and equipment & 10.7 & -3.7 & -7.5 & 1.1 & 4.6 & 6.0 & 8.3 & 7.4 & 2.1 \\
\hline Final domestic demand & 2.3 & 0.4 & -1.4 & 0.1 & -0.2 & 0.3 & 2.0 & 1.4 & 1.3 \\
\hline Inventory accumulation 2/ & -0.1 & -0.9 & -0.6 & 0.5 & 0.0 & 0.1 & -0.1 & -0.3 & 0.1 \\
\hline Total domestic demand & 2.2 & -0.5 & -2.0 & 0.6 & -0.2 & 0.3 & 1.9 & 1.1 & 1.5 \\
\hline \multicolumn{10}{|l|}{ Exports of goods and } \\
\hline nonfactor services & 13.5 & 6.4 & 4.3 & 2.5 & 10.0 & 7.1 & 12.5 & 8.3 & 6.2 \\
\hline \multicolumn{10}{|l|}{ Imports of goods and } \\
\hline nonfactor services & 10.2 & 1.2 & -1.4 & 5.4 & 7.2 & 6.7 & 11.2 & 5.7 & 6.4 \\
\hline Foreign balance $2 /$ & 1.0 & 1.7 & 2.0 & -0.8 & 1.3 & 0.5 & 1.1 & 1.5 & 0.3 \\
\hline GDP & 3.1 & 1.2 & 0.0 & -0.3 & 1.1 & 0.8 & 2.9 & 2.5 & 1.7 \\
\hline \multirow[t]{2}{*}{ Output gap (In percent of potential GDP) } & 1.8 & 1.3 & -0.2 & -1.7 & -2.0 & -2.4 & -1.0 & 0.0 & 0.0 \\
\hline & \multicolumn{9}{|c|}{ (In millions of persons, unless otherwise indicated) } \\
\hline \multicolumn{10}{|l|}{ Employment and unemployment } \\
\hline Labor force & 41.9 & 42.1 & 42.2 & 42.3 & 42.7 & 42.6 & 43.2 & 43.3 & 43.5 \\
\hline Employment & 39.1 & 39.3 & 39.1 & 38.7 & 38.9 & 38.8 & 39.0 & 39.7 & 39.9 \\
\hline Unemployment 3/ & 3.1 & 3.2 & 3.5 & 3.9 & 4.2 & 4.6 & 4.2 & 3.6 & 3.6 \\
\hline Unemployment rate (in percent) $4 /$ & 6.9 & 6.9 & 7.7 & 8.8 & 9.2 & 10.6 & 9.8 & 8.4 & 8.2 \\
\hline & \multicolumn{9}{|c|}{ (Percentage change) } \\
\hline \multicolumn{10}{|l|}{ Prices and incomes } \\
\hline GDP deflator & -0.6 & 1.2 & 1.4 & 1.2 & 1.1 & 0.7 & 0.6 & 1.8 & 0.2 \\
\hline Consumer price index (harmonized) & 1.4 & 1.9 & 1.4 & 1.0 & 1.8 & 1.9 & 1.8 & 2.3 & 2.1 \\
\hline Average hourly earnings (total economy) & 2.8 & 2.7 & 2.0 & 1.7 & 0.3 & 1.0 & 1.1 & -0.2 & 0.6 \\
\hline Unit labor cost (industry) & -1.7 & 0.5 & 1.5 & -1.3 & -3.1 & -2.5 & -2.8 & -1.5 & -0.5 \\
\hline Real disposable income 5/ & 2.1 & 2.1 & -0.2 & 0.5 & 0.3 & 0.1 & 0.9 & 0.4 & 1.1 \\
\hline Personal saving ratio (in percent) & 9.2 & 9.4 & 9.9 & 10.3 & 10.4 & 10.5 & 10.5 & 11.1 & 10.8 \\
\hline
\end{tabular}

Sources: Deutsche Bundesbank; Federal Statistical Office; IMF, World Economic Outlook; IMF, International Financial Statistics; and staff estimates and projections.

1/ 2007 estimate, 2008 IMF staff projections.

2/ Growth contribution.

3/ National accounts definition

4/ Eurostat definition.

5/ Deflated by the national accounts deflator for private consumption. 
Table 1. Germany: Basic Data (concluded)

\begin{tabular}{|c|c|c|c|c|c|c|c|c|c|}
\hline & 2000 & 2001 & 2002 & 2003 & 2004 & 2005 & 2006 & $20071 /$ & $20081 /$ \\
\hline & \multicolumn{9}{|c|}{ (In billions of Euros, unless otherwise indicated) } \\
\hline \multicolumn{10}{|l|}{ Public finances $6 / 7 /$} \\
\hline \multicolumn{10}{|l|}{ General government } \\
\hline Expenditure & 930 & 1,005 & 1,031 & 1,049 & 1,042 & 1,053 & 1,055 & 1,066 & 1,085 \\
\hline (In percent of GDP) & 45.1 & 47.6 & 48.1 & 48.5 & 47.1 & 46.9 & 45.4 & 44.0 & 43.8 \\
\hline Revenue & 957 & 945 & 953 & 962 & 958 & 977 & 1,017 & 1,065 & 1,070 \\
\hline (In percent of GDP) & 46.4 & 44.7 & 44.4 & 44.5 & 43.3 & 43.5 & 43.8 & 44.0 & 43.2 \\
\hline Overall balance & 27 & -60 & -78 & -88 & -85 & -79 & -37 & 0 & -15 \\
\hline (In percent of GDP) & 1.3 & -2.8 & -3.7 & -4.0 & -3.8 & -3.5 & -1.6 & 0.0 & -0.6 \\
\hline Structural balance & -25 & -54 & -62 & -69 & -62 & -55 & -27 & 0 & -18 \\
\hline (In percent of potential GDP) & -1.2 & -2.5 & -2.9 & -3.2 & -2.8 & -2.4 & -1.2 & 0.0 & -0.7 \\
\hline \multicolumn{10}{|l|}{ Federal government } \\
\hline Overall balance & 28 & -27 & -36 & -40 & -51 & -58 & -30 & -16 & -24 \\
\hline (In percent of GDP) & 1.4 & -1.3 & -1.7 & -1.8 & -2.3 & -2.6 & -1.3 & -0.7 & -1.0 \\
\hline General government debt & 1,211 & 1,224 & 1,278 & 1,358 & 1,430 & 1,489 & 1,533 & 1,533 & 1,548 \\
\hline (In percent of GDP) & 58.7 & 57.9 & 59.6 & 62.8 & 64.7 & 66.3 & 66.0 & 63.3 & 62.5 \\
\hline \multicolumn{10}{|l|}{ Balance of payments } \\
\hline Trade balance 8/ & 50.1 & 88.1 & 124.2 & 118.8 & 139.1 & 139.7 & 143.4 & 167.6 & 153.4 \\
\hline Services balance & -49.0 & -49.9 & -35.7 & -34.5 & -29.4 & -28.9 & -22.4 & -21.0 & -14.5 \\
\hline Net private transfers & -9.3 & -10.5 & -11.8 & -10.0 & -11.1 & -10.9 & -12.1 & -14.0 & -12.9 \\
\hline Net official transfers & -18.7 & -16.4 & -15.7 & -18.3 & -16.8 & -17.7 & -14.7 & -20.9 & -19.3 \\
\hline Current account & -35.2 & 0.4 & 43.0 & 40.9 & 94.9 & 103.1 & 117.2 & 135.0 & 130.6 \\
\hline (In percent of GDP) & -1.7 & 0.0 & 2.0 & 1.9 & 4.3 & 4.6 & 5.0 & 5.6 & 5.3 \\
\hline Foreign exchange reserves (e. o. p.) 9/ & 53.4 & 49.5 & 40.5 & 32.5 & 33.8 & 33.7 & 28.6 & 27.7 & $\ldots$ \\
\hline Monetary data & \multicolumn{9}{|c|}{ (Percentage change) } \\
\hline Money and quasi-money (M3) 10/11/ & -1.0 & 6.1 & & 3.5 & 2.2 & 5.2 & 4.8 & 10.5 & $\ldots$ \\
\hline \multirow[t]{2}{*}{ Credit to private sector $10 /$} & 5.8 & 3.2 & 0.9 & 0.0 & -0.2 & 2.1 & 3.5 & 1.8 & $\ldots$ \\
\hline & \multicolumn{9}{|c|}{ (Period average in percent) } \\
\hline \multicolumn{10}{|l|}{ Interest rates } \\
\hline Three-month interbank rate 12/ & 4.4 & 4.3 & 3.3 & 2.3 & 2.1 & 2.1 & 3.7 & 4.8 & $\ldots$ \\
\hline Yield on ten-year government bonds $12 /$ & 5.3 & 4.8 & 4.8 & 4.1 & 4.1 & 3.6 & 3.8 & 4.3 & $\ldots$ \\
\hline \multicolumn{10}{|l|}{ Exchange rates } \\
\hline Euro per US\$ (annual average) 12/ & 1.08 & 1.12 & 1.06 & 0.88 & 0.80 & 0.80 & 0.80 & 0.69 & $\ldots$ \\
\hline Nominal effective rate $(1990=100) 13 /$ & 100.0 & 101.5 & 104.7 & 112.6 & 115.8 & 114.7 & 116.6 & 120.0 & $\ldots$ \\
\hline Real effective rate $(1990=100) 14 /$ & 100.0 & 99.3 & 101.6 & 106.0 & 105.4 & 100.1 & 97.5 & 99.2 & $\ldots$ \\
\hline
\end{tabular}

6/ Data for federal government are on an administrative basis. Data for the general government are on a national accounts basis. Debt data are end-of-year data for the general government in accordance with Maastricht definitions.

$7 /$ Government expenditure in 2000 includes, as a negative entry, the proceeds from the sales of mobile phone licenses of euro 50.8 billion (2.5 percent of GDP). The proceeds also affect the financial (but not structural) balances and the government debt.

8 / Including supplementary trade items.

9/ From 1999 onward data reflect Germany's position in the euro area. Data for 2007 refer to December.

10/ Data for 2007 refer to the change from December 2006 to December 2007.

11/ Data reflect Germany's contribution to M3 of the euro area; data not shown for 2002 because of a series break.

12/ Data for 2007 refer to December.

13/ Data for 2007 refer to December.

14/ Based on relative normalized unit labor cost in manufacturing. Data for 2007 refer to December. 
Table 2. Germany: Medium-Term Balance of Payments, 2005-13

\begin{tabular}{|c|c|c|c|c|c|c|c|c|c|}
\hline & \multicolumn{9}{|c|}{ Projections } \\
\hline & 2005 & 2006 & 2007 & 2008 & 2009 & 2010 & 2011 & 2012 & 2013 \\
\hline & \multicolumn{9}{|c|}{ (In billions of Euros, unless otherwise indicated) } \\
\hline Current account & 103 & 117 & 135 & 131 & 122 & 117 & 114 & 112 & 104 \\
\hline In percent of GDP & 4.6 & 5.0 & 5.6 & 5.3 & 4.8 & 4.5 & 4.2 & 4.0 & 3.6 \\
\hline Trade balance & 140 & 143 & 168 & 153 & 152 & 156 & 162 & 166 & 167 \\
\hline Exports & 787 & 900 & 982 & 1,047 & 1,105 & 1,166 & 1,230 & 1,297 & 1,366 \\
\hline Imports & -647 & -757 & -815 & -894 & -953 & $-1,010$ & $-1,068$ & $-1,131$ & $-1,199$ \\
\hline Nonfactor services & -29 & -22 & -21 & -15 & -22 & -32 & -40 & -49 & -57 \\
\hline Exports & 129 & 142 & 155 & 165 & 174 & 184 & 194 & 204 & 215 \\
\hline Imports & -158 & -164 & -176 & -179 & -196 & -215 & -234 & -253 & -272 \\
\hline Balance on Factor Income & 289 & 353 & 373 & 398 & 412 & 426 & 441 & 457 & 473 \\
\hline Credit & 155 & 188 & 198 & 211 & 218 & 226 & 234 & 242 & 251 \\
\hline Debit & -134 & -165 & -175 & -187 & -193 & -200 & -207 & -214 & -222 \\
\hline Current transfers, net & -29 & -27 & -35 & -32 & -33 & -34 & -35 & -33 & -35 \\
\hline Capital and financial accounts & -125 & -146 & -132 & -131 & -122 & -116 & -115 & -112 & -106 \\
\hline Capital account, net & -1 & 0 & 0 & 0 & 0 & 0 & 0 & 0 & 0 \\
\hline FDI, net & -16 & -29 & -30 & -31 & -32 & -33 & -34 & -35 & -36 \\
\hline Portfolio investment, net & -31 & -5 & -5 & -5 & -6 & -6 & -6 & -6 & -6 \\
\hline Other & -79 & -115 & -97 & -94 & -85 & -78 & -75 & -71 & -63 \\
\hline Reserve assets & 2 & 3 & 0 & 0 & 0 & 0 & 0 & 0 & 0 \\
\hline Errors and omissions & 22 & 29 & -3 & 0 & 0 & 0 & 1 & 1 & 1 \\
\hline
\end{tabular}

Source: WEO. 
Table 3. Germany: Core Set of Financial Soundness Indicators for Banks, 1998-2006

(In percent)

\begin{tabular}{|c|c|c|c|c|c|c|c|c|c|}
\hline & 1998 & 1999 & 2000 & 2001 & 2002 & 2003 & 2004 & 2005 & 2006 \\
\hline \multicolumn{10}{|l|}{ Capital adequacy } \\
\hline Regulatory capital to risk-weighted assets & 10.5 & 10.8 & 10.9 & 11.2 & 11.9 & 12.4 & 12.4 & 12.2 & 12.5 \\
\hline Commercial banks & 10.1 & 10.9 & 11.3 & 12.0 & 12.7 & 12.8 & 12.5 & 11.6 & 12.5 \\
\hline Landesbanken & 9.6 & 9.9 & 10.0 & 10.4 & 11.5 & 13.0 & 12.2 & 12.1 & 11.7 \\
\hline Savings banks & 10.8 & 10.8 & 10.6 & 10.7 & 11.1 & 11.4 & 12.0 & 12.5 & 13.0 \\
\hline Credit cooperatives & 11.0 & 11.1 & 11.0 & 10.9 & 10.9 & 11.6 & 12.0 & 12.1 & 12.2 \\
\hline Regulatory Tier I capital to risk-weighted assets $1 /$ & 6.8 & 6.9 & 7.0 & 7.2 & 7.8 & 8.2 & 8.0 & 8.0 & 8.2 \\
\hline Commercial banks & 6.7 & 7.3 & 7.6 & 8.2 & 8.7 & 9.0 & 8.3 & 7.9 & 8.4 \\
\hline Landesbanken & 5.5 & 5.6 & 5.5 & 5.8 & 7.0 & 7.8 & 7.1 & 7.3 & 7.1 \\
\hline Savings banks & 7.0 & 7.0 & 6.9 & 7.0 & 7.2 & 7.4 & 7.7 & 8.0 & 8.4 \\
\hline Credit cooperatives & 7.2 & 7.2 & 7.3 & 7.3 & 7.5 & 8.0 & 8.3 & 8.5 & 9.1 \\
\hline \multicolumn{10}{|l|}{ Asset composition and quality } \\
\hline \multicolumn{10}{|l|}{ Sectoral distribution of loans to total loans } \\
\hline Loan to households & 33.3 & 31.2 & 30.6 & 29.7 & 29.5 & 29.7 & 29.3 & 28.5 & 27.6 \\
\hline Commercial banks & $\ldots$ & 31.0 & 29.2 & 27.5 & 26.8 & 26.1 & 25.8 & 24.8 & 23.9 \\
\hline Landesbanken & $\ldots$ & 8.3 & 8.2 & 7.9 & 7.5 & 7.5 & 7.1 & 6.8 & 6.2 \\
\hline Savings banks & $\ldots$ & 63.8 & 63.6 & 62.4 & 61.9 & 62.9 & 62.3 & 62.2 & 61.1 \\
\hline Credit cooperatives & $\ldots$ & 66.6 & 68.0 & 66.4 & 67.0 & 68.1 & 68.3 & 69.3 & 68.5 \\
\hline Loans to non-financial corporations & 19.4 & 17.3 & 17.4 & 17.1 & 16.6 & 16.0 & 15.2 & 14.5 & 14.3 \\
\hline Commercial banks & $\ldots$ & 22.3 & 20.7 & 19.3 & 17.7 & 15.6 & 14.3 & 13.3 & 12.6 \\
\hline Landesbanken & $\ldots$ & 18.9 & 19.5 & 19.7 & 18.9 & 18.5 & 17.8 & 16.7 & 17.0 \\
\hline Savings banks & $\ldots$ & 17.7 & 18.5 & 18.8 & 18.6 & 18.3 & 18.0 & 17.6 & 17.3 \\
\hline Credit cooperatives & $\ldots$ & 13.0 & 13.6 & 13.4 & 13.2 & 12.9 & 12.4 & 12.0 & 12.1 \\
\hline NPLs to gross loans & 4.4 & 4.1 & 4.6 & 4.5 & 5.0 & 5.2 & 4.9 & 4.0 & 3.4 \\
\hline Commercial banks & 5.2 & 5.0 & 5.7 & 5.2 & 5.2 & 5.1 & 4.5 & 3.3 & 2.6 \\
\hline Landesbanken & 2.8 & 2.5 & 2.7 & 2.8 & 3.7 & 4.4 & 4.1 & 2.9 & 2.0 \\
\hline Savings banks & 6.1 & 5.7 & 5.6 & 5.9 & 6.4 & 6.8 & 6.9 & 6.6 & 5.9 \\
\hline Credit cooperatives & 6.5 & 6.4 & 6.9 & 7.2 & 8.0 & 8.1 & 8.2 & 7.3 & 6.6 \\
\hline NPLs net of provisions to capital & 41.4 & 38.6 & 44.0 & 45.4 & 47.8 & 50.4 & 44.5 & 34.6 & 28.7 \\
\hline Commercial banks & 39.0 & 38.5 & 40.7 & 51.2 & 47.2 & 54.5 & 41.2 & 30.6 & 24.5 \\
\hline Landesbanken 2/ & 32.5 & 26.0 & 29.6 & 27.9 & 31.6 & 34.9 & 37.4 & 25.0 & $16.1^{\text {a) }}$ \\
\hline Savings banks & 56.4 & 51.6 & 49.2 & 52.1 & 53.6 & 58.0 & 54.2 & 50.4 & 43.3 \\
\hline Credit cooperatives & 47.8 & 49.7 & 51.9 & 53.5 & 61.0 & 58.3 & 57.2 & 49.0 & 43.0 \\
\hline \multicolumn{10}{|l|}{ Earnings and profitability } \\
\hline Return on average assets (after-tax) & 0.3 & 0.2 & 0.2 & 0.2 & 0.1 & -0.1 & 0.1 & 0.3 & 0.3 \\
\hline Commercial banks & 0.6 & 0.3 & 0.3 & 0.2 & 0.0 & -0.3 & -0.1 & 0.5 & 0.3 \\
\hline Landesbanken & 0.1 & 0.1 & 0.1 & 0.1 & 0.1 & -0.2 & 0.0 & 0.2 & 0.3 \\
\hline Savings banks & 0.3 & 0.2 & 0.3 & 0.2 & 0.2 & 0.2 & 0.2 & 0.3 & 0.2 \\
\hline Credit cooperatives & 0.2 & 0.2 & 0.2 & 0.2 & 0.3 & 0.3 & 0.3 & 0.5 & 0.5 \\
\hline Return on average equity (after-tax) & 10.2 & 6.5 & 6.1 & 4.6 & 2.9 & -1.5 & 1.9 & 9.2 & 7.5 \\
\hline Commercial banks & 15.2 & 7.0 & 7.3 & 4.2 & 0.0 & -6.6 & -1.4 & 15.5 & 9.1 \\
\hline Landesbanken & 6.3 & 5.9 & 4.2 & 4.0 & 1.9 & -5.2 & -0.8 & 5.6 & 9.7 \\
\hline Savings banks & 6.5 & 6.1 & 6.1 & 5.1 & 4.7 & 4.0 & 5.0 & 5.6 & 5.0 \\
\hline Credit cooperatives & 5.1 & 4.7 & 4.1 & 4.4 & 6.6 & 5.2 & 5.3 & 9.0 & 8.5 \\
\hline Interest margin to gross income & 75.0 & 73.2 & 67.8 & 69.8 & 73.4 & 70.2 & 73.5 & 68.2 & 68.2 \\
\hline Commercial banks & 64.7 & 61.7 & 52.7 & 56.2 & 63.7 & 56.5 & 64.9 & 55.3 & 61.8 \\
\hline Landesbanken & 72.0 & 77.6 & 72.4 & 75.0 & 75.8 & 79.0 & 79.4 & 83.2 & 70.3 \\
\hline Savings banks & 81.9 & 81.3 & 80.9 & 80.8 & 81.3 & 80.6 & 79.6 & 79.0 & 77.7 \\
\hline Credit cooperatives & 79.0 & 77.1 & 76.5 & 78.3 & 79.1 & 75.4 & 75.5 & 74.7 & 65.3 \\
\hline Noninterest expenses to gross income & 63.6 & 66.0 & 68.4 & 71.4 & 67.2 & 66.5 & 65.5 & 61.0 & 62.3 \\
\hline Commercial banks & 67.8 & 73.9 & 75.4 & 80.4 & 74.2 & 74.0 & 73.5 & 59.8 & 66.0 \\
\hline Landesbanken & 46.5 & 54.8 & 55.9 & 57.1 & 56.1 & 53.1 & 53.5 & 59.3 & 53.6 \\
\hline Savings banks & 66.5 & 65.7 & 68.9 & 69.9 & 66.5 & 66.4 & 64.9 & 66.0 & 65.8 \\
\hline Credit cooperatives & 72.4 & 71.2 & 74.5 & 76.7 & 73.1 & 69.6 & 68.7 & 70.0 & 64.4 \\
\hline \multicolumn{10}{|l|}{ Liquidity } \\
\hline Liquid assets to total short-term liabilities $3 /$ & $\ldots$ & $\ldots$ & 120.9 & 121.1 & 121.0 & 123.5 & 124.4 & 122.0 & 120.9 \\
\hline Commercial banks & $\ldots$ & $\ldots$ & 109.0 & 111.0 & 110.9 & 111.7 & 110.2 & 110.7 & 111.8 \\
\hline Landesbanken & $\ldots$ & $\ldots$ & 110.2 & 104.0 & 107.1 & 115.5 & 129.9 & 122.4 & 118.8 \\
\hline Savings banks & $\ldots$ & $\ldots$ & 202.5 & 212.6 & 211.6 & 207.8 & 221.6 & 224.2 & 206.9 \\
\hline Credit cooperatives & $\ldots$ & $\ldots$ & 178.8 & 184.0 & 193.4 & 189.6 & 193.4 & 181.4 & 174.8 \\
\hline \multicolumn{10}{|l|}{ Sensitivity to market risk } \\
\hline Net open positions in FX to capital & 14.5 & 11.3 & 11.0 & 10.7 & 11.4 & 6.7 & 6.9 & 6.9 & 6.7 \\
\hline Commercial banks & 19.8 & 11.9 & 7.3 & 7.2 & 5.2 & 6.1 & 4.4 & 5.7 & 10.1 \\
\hline Landesbanken & 12.3 & 10.1 & 11.7 & 11.6 & 14.7 & 4.6 & 6.7 & 5.6 & 4.2 \\
\hline Savings banks & 9.5 & 11.9 & 13.6 & 14.3 & 13.8 & 12.2 & 11.1 & 11.7 & 10.1 \\
\hline Credit cooperatives & 19.9 & 19.7 & 21.8 & 21.7 & 20.8 & 16.1 & 15.6 & 14.0 & 11.3 \\
\hline
\end{tabular}

Source: Deutsche Bundesbank. The authorities provide annual data only and disseminate them once a year.

1/ According to Capital Adequacy Regulation, Principle I.

2/ Limited comparability of 2006 data with prior years.

3/ 2005-06 data in accordance with IMF's FSICompilation Guide. 
Table 4. Germany: Encouraged and Other Financial Soundness Indicators, 1998-2006 (In percent, unless otherwise indicated)

\begin{tabular}{|c|c|c|c|c|c|c|c|c|c|}
\hline & 1998 & 1999 & 2000 & 2001 & 2002 & 2003 & 2004 & 2005 & 2006 \\
\hline \multicolumn{10}{|l|}{ Corporate sector } \\
\hline Total debt to equity $1 /$ & 94.3 & 80.6 & 97.5 & 106.0 & 152.8 & 130.9 & 121.2 & 111.2 & 103.2 \\
\hline Total debt to GDP & 136.6 & 144.6 & 159.9 & 162.6 & 165.0 & 163.2 & 154.2 & 152.3 & 154.0 \\
\hline Return on invested capital 3/ 4/ & 8.3 & 6.5 & 6.3 & 7.4 & 8.8 & 8.3 & 8.9 & 9.1 & 9.1 \\
\hline Earnings to interest and principal expenses $1 / 5 /$ & 635.6 & 561.9 & 495.6 & 513.8 & 536.9 & 570.8 & 709.4 & 760.9 & 731.1 \\
\hline Number of applications for protection from creditors $1 / 6$ / & 17,941 & 18,006 & 18,389 & 21,019 & 23,642 & 23,840 & 22,474 & 19,540 & 15,704 \\
\hline \multicolumn{10}{|l|}{ Deposit-taking institutions } \\
\hline Capital to assets & 4.0 & 3.7 & 3.7 & 3.8 & 4.1 & 4.2 & 4.0 & 4.1 & 4.3 \\
\hline Commercial banks & 5.7 & 5.0 & 4.7 & 4.9 & 5.2 & 5.0 & 4.4 & 4.4 & 4.4 \\
\hline Landesbanken & 3.7 & 3.3 & 3.4 & 3.8 & 3.8 & 4.0 & 4.0 & 4.0 & 3.9 \\
\hline Savings banks & 4.1 & 3.8 & 3.9 & 4.0 & 4.2 & 4.3 & 4.5 & 4.6 & 4.8 \\
\hline Credit cooperatives & 4.9 & 4.6 & 4.9 & 4.7 & 4.9 & 5.1 & 5.3 & 5.4 & 5.7 \\
\hline \multicolumn{10}{|l|}{ Geographical distribution of loans to total loans } \\
\hline Germany & 85.3 & 85.4 & 83.6 & 81.3 & 80.0 & 78.6 & 76.8 & 75.2 & 72.6 \\
\hline EU-member countries & 8.4 & 8.6 & 9.6 & 11.6 & 13.2 & 14.6 & 16.9 & 17.3 & 19.5 \\
\hline Others & 6.3 & 6.0 & 6.8 & 7.1 & 6.8 & 6.8 & 6.3 & 7.5 & 7.9 \\
\hline FX loans to total loans & 9.1 & 7.8 & 9.3 & 10.2 & 9.6 & 9.1 & 9.6 & 10.2 & 10.5 \\
\hline Personnel expenses to noninterest expenses & 56.0 & 54.8 & 54.1 & 53.1 & 53.1 & 53.8 & 54.4 & 55.1 & 56.4 \\
\hline Commercial banks & 54.1 & 51.3 & 50.4 & 49.2 & 48.5 & 49.4 & 49.7 & 50.7 & 52.5 \\
\hline Landesbanken & 52.8 & 51.0 & 51.9 & 49.8 & 49.6 & 49.0 & 50.2 & 50.5 & 55 \\
\hline Savings banks & 59.9 & 59.9 & 60.0 & 59.3 & 59.5 & 60.6 & 61.3 & 61.8 & 61.5 \\
\hline Credit cooperatives & 58.2 & 58.5 & 57.8 & 58.4 & 59.0 & 59.0 & 59.2 & 60.1 & 60.9 \\
\hline Trading and fee income to total income & 25.0 & 26.8 & 32.2 & 30.2 & 26.6 & 29.8 & 26.5 & 31.8 & 31.8 \\
\hline Commercial banks & 35.3 & 38.3 & 47.3 & 43.8 & 36.3 & 43.5 & 35.1 & 44.7 & 38.2 \\
\hline Landesbanken & 28.0 & 22.4 & 27.6 & 25.0 & 24.2 & 21.0 & 20.6 & 16.8 & 29.7 \\
\hline Savings banks & 18.1 & 18.7 & 19.1 & 19.2 & 18.7 & 19.4 & 20.4 & 21.0 & 22.3 \\
\hline Credit cooperatives & 21.0 & 22.9 & 23.5 & 21.7 & 20.9 & 24.6 & 24.5 & 25.3 & 34.7 \\
\hline Customer deposits to total (non-interbank) loans & $\ldots$ & 63.5 & 63.9 & 64.0 & 65.4 & 67.1 & 70.0 & 71.8 & 75.2 \\
\hline Commercial banks & $\ldots$ & 62.6 & 63.0 & 68.6 & 74.2 & 78.4 & 85.3 & 85.5 & 95.7 \\
\hline Landesbanken & $\ldots$ & 35.2 & 38.4 & 34.3 & 30.1 & 32.8 & 35.4 & 40.6 & 42.9 \\
\hline Savings banks & $\ldots$ & 104.7 & 101.8 & 101.1 & 100.3 & 99.8 & 101.0 & 102.2 & 103.3 \\
\hline Credit cooperatives & $\ldots$ & 113.6 & 108.0 & 110.3 & 110.8 & 111.7 & 113.2 & 113.6 & 113.1 \\
\hline Spread between highest and lowest interbank rates $7 /$ & $\ldots$ & $\ldots$ & $\ldots$ & $\ldots$ & $\ldots$ & $\ldots$ & $\ldots$ & 2.0 & 2.6 \\
\hline Spread between reference loan and deposit rates $8 /$ & $\cdots$ & $\cdots$ & $\ldots$ & $\cdots$ & $\ldots$ & 379 & 366 & 353 & 317 \\
\hline \multicolumn{10}{|l|}{ Insurance sector } \\
\hline Solvency ratio, Life & $\ldots$ & $\ldots$ & & 199 & 170 & 176 & 177 & 190 & n.a. \\
\hline Solvency ratio, Non-life & $\ldots$ & $\ldots$ & 350 & 343 & 337 & 346 & 286 & 255 & n.a. \\
\hline Return on average equity, Life 9/ & 11.9 & 11.4 & 12.5 & 7.0 & 3.4 & 5.7 & 8.7 & n.a. & n.a. \\
\hline Return on average equity, Non-life 9/ & 8.1 & 7.3 & 8.7 & 8.9 & 2.8 & 4.1 & 6.8 & n.a. & n.a. \\
\hline \multicolumn{10}{|l|}{ Market liquidity } \\
\hline Average bid-ask spread in the securities market (government bills) & $\cdots$ & $\cdots$ & $\cdots$ & $\cdots$ & $\cdots$ & $\cdots$ & $\cdots$ & 0.0 & 0.0 \\
\hline Average bid-ask spread in the securities market (corporate securities) & $\cdots$ & $\ldots$ & $\ldots$ & $\ldots$ & $\ldots$ & $\ldots$ & $\ldots$ & 0.1 & 0.1 \\
\hline \multicolumn{10}{|l|}{ Households } \\
\hline Household debt to GDP 1/ & 69.7 & 72.9 & 73.4 & 72.7 & 72.4 & 72.5 & 71.2 & 69.9 & 67.4 \\
\hline Household debt service and principal payments to income 1/5/ & 4.9 & 4.7 & 5.1 & 5.0 & 4.7 & 4.2 & 3.9 & 3.7 & 3.9 \\
\hline \multicolumn{10}{|l|}{ Real estate markets } \\
\hline Real estate prices, new dwellings & 99 & 99 & 100 & 101 & 102 & 100 & 100 & 100 & 101 \\
\hline Real estate prices, resale & 99 & 100 & 100 & 100 & 98 & 97 & 95 & 93 & 93 \\
\hline Residential real estate loans to total loans & 13.7 & 16.2 & 16.4 & 16.1 & 16.2 & 18.0 & 17.8 & 17.8 & 17.7 \\
\hline Commercial real estate loans to total loans & 6.8 & 6.4 & 6.4 & 6.2 & 6.2 & 6.6 & 6.4 & 6.1 & 5.8 \\
\hline
\end{tabular}

Source: Deutsche Bundesbank. The authorities provide annual data only and disseminate them once a year.

$1 /$ Indicator compiled according to definitions of the Compilation Guide on FSIs.

2/ Return defined as net operating income less taxes, where net operating income and taxes are

compiled according to the FSI Compilation Guide.

3/ Invested capital estimated as balance sheet total less other accounts payable (AF.7 according to ESA 1995).

4/ Excluding principal payments.

5/ Resident enterprises that filed for bankruptcy.

6/ Spread between highest and lowest three month money market rates as reported by Frankfurt banks (basis points).

7/ Spread in basis points.

8/ Profits after tax devided by equity.

9/ Residential property index (yearly average, $2000=100$ ); aggregation of data for new dwellings and resale is not available 


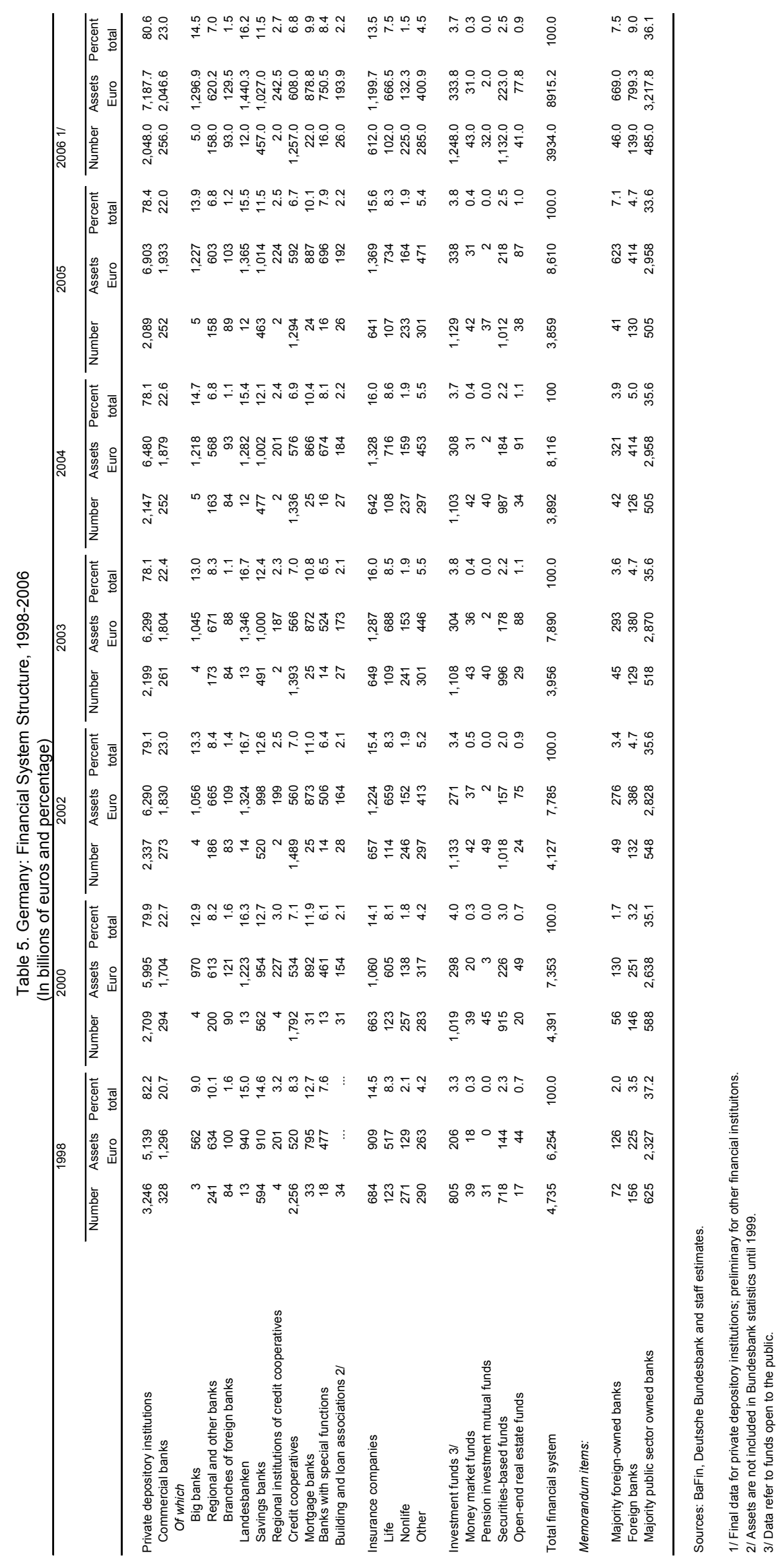


Table 6. Germany: General Government Finances, 2002-12

\begin{tabular}{|c|c|c|c|c|c|c|c|c|c|c|c|}
\hline & & & & & & Est. & & Sta & f projectio & & \\
\hline & 2002 & 2003 & 2004 & 2005 & 2006 & 2007 & 2008 & 2009 & 2010 & 2011 & 2012 \\
\hline & & & & & (In & billions of & uros) & & & & \\
\hline Revenue & 952.5 & 961.9 & 958.1 & 977.0 & $1,017.4$ & $1,065.3$ & $1,069.7$ & $1,099.8$ & $1,120.7$ & $1,139.9$ & $1,173.6$ \\
\hline Current & 944.0 & 952.9 & 948.6 & 967.1 & $1,008.1$ & $1,055.9$ & $1,060.1$ & $1,089.9$ & $1,110.6$ & $1,129.4$ & $1,162.8$ \\
\hline Direct taxes & 227.2 & 226.1 & 221.1 & 227.6 & 250.0 & 265.2 & 262.3 & 270.1 & 275.1 & 281.7 & 290.5 \\
\hline Indirect taxes & 250.3 & 255.7 & 260.2 & 265.5 & 280.4 & 312.0 & 317.0 & 325.3 & 334.9 & 341.4 & 352.0 \\
\hline Social security contributions & 390.7 & 396.3 & 396.9 & 396.9 & 401.1 & 401.9 & 409.3 & 423.2 & 431.0 & 438.7 & 450.6 \\
\hline Other current & 75.8 & 74.9 & 70.5 & 77.2 & 76.6 & 76.7 & 71.5 & 71.3 & 69.5 & 67.6 & 69.7 \\
\hline Capital & 8.5 & 9.0 & 9.5 & 9.9 & 9.3 & 9.4 & 9.6 & 9.9 & 10.2 & 10.5 & 10.8 \\
\hline Primary expenditure & 968.2 & 984.9 & 979.3 & 990.1 & 989.7 & $1,000.3$ & $1,019.4$ & $1,038.4$ & $1,058.8$ & $1,076.4$ & $1,103.4$ \\
\hline Current & 899.2 & 916.5 & 915.3 & 926.1 & 927.5 & 937.6 & 953.9 & 970.7 & 988.7 & $1,004.6$ & $1,029.3$ \\
\hline Wages & 168.7 & 169.2 & 169.5 & 168.5 & 167.7 & 167.7 & 169.5 & 170.8 & 171.7 & 173.3 & 174.7 \\
\hline Goods and services & 88.4 & 90.4 & 91.2 & 96.9 & 97.8 & 101.0 & 104.5 & 107.2 & 109.3 & 108.8 & 111.2 \\
\hline Subsidies & 31.7 & 29.7 & 28.7 & 27.2 & 26.8 & 28.2 & 30.1 & 31.9 & 33.8 & 33.9 & 34.9 \\
\hline Social benefits & 579.8 & 594.2 & 592.7 & 598.2 & 600.1 & 605.3 & 611.9 & 620.3 & 631.4 & 646.0 & 663.8 \\
\hline Other current & 30.6 & 32.9 & 33.2 & 35.3 & 35.2 & 35.3 & 37.9 & 40.6 & 42.5 & 42.6 & 44.7 \\
\hline Capital & 69.0 & 68.4 & 64.0 & 64.0 & 62.1 & 62.7 & 65.6 & 67.7 & 70.1 & 71.8 & 74.1 \\
\hline Primary balance & -15.7 & -23.0 & -21.2 & -13.1 & 27.8 & 65.0 & 50.2 & 61.5 & 61.9 & 63.5 & 70.2 \\
\hline Interest & 62.7 & 64.3 & 62.4 & 62.5 & 65.1 & 65.4 & 65.4 & 66.5 & 64.6 & 64.1 & 60.8 \\
\hline Overall balance & -78.3 & -87.3 & -83.6 & -75.6 & -37.3 & -0.4 & -15.2 & -5.0 & -2.7 & -0.6 & 9.3 \\
\hline & & & & & & percent o & GDP) & & & & \\
\hline Revenue & 44.4 & 44.5 & 43.3 & 43.5 & 43.8 & 44.0 & 43.2 & 43.3 & 42.8 & 42.2 & 42.2 \\
\hline Current & 44.0 & 44.0 & 42.9 & 43.1 & 43.4 & 43.6 & 42.8 & 42.9 & 42.4 & 41.8 & 41.8 \\
\hline Direct taxes & 10.6 & 10.4 & 10.0 & 10.1 & 10.8 & 10.9 & 10.6 & 10.6 & 10.5 & 10.4 & 10.4 \\
\hline Indirect taxes & 11.7 & 11.8 & 11.8 & 11.8 & 12.1 & 12.9 & 12.8 & 12.8 & 12.8 & 12.6 & 12.6 \\
\hline Social security contributions & 18.2 & 18.3 & 17.9 & 17.7 & 17.3 & 16.6 & 16.5 & 16.6 & 16.5 & 16.3 & 16.2 \\
\hline Other current & 3.5 & 3.5 & 3.2 & 3.4 & 3.3 & 3.2 & 2.9 & 2.8 & 2.7 & 2.5 & 2.5 \\
\hline Capital & 0.4 & 0.4 & 0.4 & 0.4 & 0.4 & 0.4 & 0.4 & 0.4 & 0.4 & 0.4 & 0.4 \\
\hline Primary expenditure & 45.2 & 45.5 & 44.3 & 44.1 & 42.6 & 41.3 & 41.1 & 40.8 & 40.4 & 39.9 & 39.6 \\
\hline Current & 42.0 & 42.4 & 41.4 & 41.3 & 39.9 & 38.7 & 38.5 & 38.2 & 37.8 & 37.2 & 37.0 \\
\hline Wages & 7.9 & 7.8 & 7.7 & 7.5 & 7.2 & 6.9 & 6.8 & 6.7 & 6.6 & 6.4 & 6.3 \\
\hline Goods and services & 4.1 & 4.2 & 4.1 & 4.3 & 4.2 & 4.2 & 4.2 & 4.2 & 4.2 & 4.0 & 4.0 \\
\hline Subsidies & 1.5 & 1.4 & 1.3 & 1.2 & 1.2 & 1.2 & 1.2 & 1.3 & 1.3 & 1.3 & 1.3 \\
\hline Social benefits & 27.1 & 27.5 & 26.8 & 26.6 & 25.8 & 25.0 & 24.7 & 24.4 & 24.1 & 23.9 & 23.9 \\
\hline Other current & 1.4 & 1.5 & 1.5 & 1.6 & 1.5 & 1.5 & 1.5 & 1.6 & 1.6 & 1.6 & 1.6 \\
\hline Capital & 3.2 & 3.2 & 2.9 & 2.9 & 2.7 & 2.6 & 2.6 & 2.7 & 2.7 & 2.7 & 2.7 \\
\hline Primary balance & -0.7 & -1.1 & -1.0 & -0.6 & 1.2 & 2.7 & 2.0 & 2.4 & 2.4 & 2.4 & 2.5 \\
\hline Interest & 2.9 & 3.0 & 2.8 & 2.8 & 2.8 & 2.7 & 2.6 & 2.6 & 2.5 & 2.4 & 2.2 \\
\hline Overall balance & -3.7 & -4.0 & -3.8 & -3.4 & -1.6 & 0.0 & -0.6 & -0.2 & -0.1 & 0.0 & 0.3 \\
\hline Memorandum item: & & & & & & & & & & & \\
\hline Structural fiscal balance & -2.9 & -3.2 & -2.8 & -2.4 & -1.2 & 0.0 & -0.7 & -0.3 & -0.1 & 0.0 & 0.3 \\
\hline Gross public debt end-year & 59.6 & 62.8 & 64.7 & 66.3 & 66.0 & 63.3 & 62.5 & 61.1 & 59.4 & 59.3 & 59.1 \\
\hline
\end{tabular}

Sources: Ministry of Finance; and Fund staff projections. 


\section{APPENDIX I. Germany: Fund Relations}

(As of December 31, 2007)

- Mission: November 28 to December 10, 2007 in Frankfurt, Bonn, and Berlin. The concluding statement of the mission is available at http://www.imf.org/external/np/ms/2007/121007.htm.

- $\quad$ Staff team: Messrs. Kähkönen (Head), Mody, Odenius, Ms. Carare (EUR) and Messrs. Seelig and Kiff (MCM). Mr. Ahmad (FAD) joined the mission as an expert on fiscal federalism.

- $\quad$ Country interlocutors: The Bundesbank President Weber, Federal Financial Supervisory Authority (BaFin) Vice-President Caspari, State Secretaries Anzinger (Labor and Social Security), Mirow (Finance), and Pfaffenbach (Economy), members of the German Council of Economic Experts, and senior representatives at the Chancellery, several ministries, the Bundesbank, and BaFin. Mr. von Stenglin, the Alternate Executive Director for Germany, also participated in the discussions. Meetings took place with parliamentarians, Länder representatives, labor unions, employers, research institutes, and financial market participants.

- $\quad$ Fund relations: The previous Article IV consultation took place on December 8, 2006. The associated Executive Board's assessment and staff report are available at http://www.imf.org/external/pubs/cat/longres.cfm?sk=20177.0 .

- $\quad$ Selected issues papers: (1) The modest effect of the German VAT hike: The role of inflation smoothing; (2) Growthlinkages within Europe; (3) Alleviating shortages of skilled labor; and (4) Germany's corporate governance: Turning inside out.

I. Membership Status: Joined August 14, 1952.

II. General Resources Account:

Quota

Fund holdings of currency

Reserve position in Fund

III. SDR Department:

Net cumulative allocation

Holdings

IV. Outstanding Purchases and Loans:

V. Financial Arrangements:
SDR Million

$13,008.20$

$12,124.67$

883.61

SDR Million

$1,210.76$

$1,368.05$

None

None
\% Quota

100.00

93.21

6.79

\section{\% Allocation}

100.00

112.99 


\section{Projected Payments to Fund:}

(SDR Million; based on existing use of resources and present holdings of SDRs):

\begin{tabular}{lrrrrr} 
& \multicolumn{6}{c}{ Forthcoming } \\
\cline { 2 - 6 } & 2008 & 2009 & 2010 & 2011 & 2012 \\
Principal & -- & -- & -- & -- & -- \\
Charges/Interest & -0.06 & 0.06 & 0.06 & 0.06 & 0.06 \\
Total & 0.06 & 0.06 & 0.06 & 0.06 & 0.06
\end{tabular}

\section{Exchange Rate Arrangement:}

Germany's currency is the euro, which floats freely and independently against other currencies.

Germany is an Article VIII member and maintains an exchange system free of restrictions on payments and transfers for current international transactions. It maintains measures adopted for security reasons, which have been notified to the Fund for approval in accordance with the procedures of Decision 144 (EBD/08/5, January 16, 2008)and does so solely for the preservation of national or international security.

\section{Anti-Money Laundering/Combating the Financing of Terrorism (AML/CFT)}

The authorities have moved towards a more risk-based approach, in which the intensity of audits and inspections should reflect institutions' AML/CFT risk. A dialogue with the associations of certified public accountants and other auditors has led to a revised AML/CFT assessment methodology in 2005. Legal revisions also granted the BaFin the power to freeze funds without a court order or other involvement of prosecution authorities if facts suggest that funds serve the purpose of terrorist financing. BaFin can now also require financial holding groups and financial conglomerates to develop a coordinated risk management approach for the whole group.

\section{Staff Analytical Work on Germany, 2003-07}

\section{Growth and Competitiveness}

- Alleviating Shortages of Skilled Labor and their Impact on the Economy, forthcoming Working Paper.

- Growth Linkages within Europe,see Selected Issues Chapter 2.

- What explains Germany's Rebounding Export Market Share? CESifo Working Paper No. 1957.

- Long-run Growth in Germany. IMF Country Report No. 06/17.

- Does Excessive Regulation Impede Growth in Germany? IMF Country Report No. 06/17.

- The Performance of Germany's Non-Financial Corporate Sector - An International Perspective. IMF Country Report No. 06/17. 
- Investment Trends in OECD Countries: Long-Term Developments and Future Prospects. IMF Country Report No. 04/340.

- Does PPP hold in the Long Run? Germany and Switzerland. IMF Country Report No. 04/340.

- Business Investment in the Current Cycle. IMF Country Report No. 03/342.

\section{Inflation}

- The modest effect of the German VAT hike: Role of inflation smoothing, forthcoming Working Paper.

\section{Fiscal Policy and Entitlement Programs}

- Tax Reform and Debt Sustainability in Germany: An Assessment Using the Global Fiscal Model. IMF Country Report No. 06/436.

- Business Tax Reform. Forthcoming Selected Issues Paper.

- Why is Germany's Deficit so Large?, IMF Country Report No. 06/17.

- A Preliminary Public Sector Balance Sheet for Germany, IMF Country Report No. 06/17.

- Germany: A Long-Run Fiscal Scenario Based on Current Policies, IMF Country Report No. 06/17.

- Pensions and Growth. IMF Country Report No. 04/340.

- Federalism and the Political Economy of Adjustment. IMF Country Report No. $04 / 340$.

\section{Labor Markets}

- The Employment Effects of Labor and Product Markets Deregulation and their Implications for Structural Reform. CESifo Working Paper No 1709, May 2006.

- Employment, Unemployment, and Labor Supply in Germany. IMF Country Report No. 04/340.

- The Unbearable Stability of the German Wage Structure: Evidence and Interpretation. IMF Staff Papers, August 2004.

\section{The Financial System}

- Landesbanken: A Measure of the Costs for Taxpayers. IMF Country Report No. 06/436.

- The German Banking Sector: Credit Decline, Soundness and Efficiency. IMF Country Report No. 06/17.

- Germany's Three-Pillar Banking System. IMF Occasional Paper 233 (2004).

- Germany's Financial System: International Linkages and the Transmission of Financial Shocks. IMF Country Report No. 03/342.

\section{Corporate Governance}

- Germany's Corporate Governance: Turning Inside Out, see Selected Issues Chapter 4. 


\section{APPENDIX II. Germany: Statistical Issues}

Germany's economic and financial statistics are adequate for surveillance purposes. Germany has a full range of statistical publications and subscribes to the Fund's Special Data Dissemination Standard (SDDS). The authorities make substantial use of the Internet to facilitate on-line access to data and press information.

Germany adopted the European System of Integrated Economic Accounts 1995 (ESA95) in 1999. The 2005 ROSC Data Module mission found that the macroeconomic statistics generally follow internationally accepted standards and guidelines on concepts and definitions, scope, classification and sectorization, and basis for recording. However, the sources for estimating value added for a few categories of service industries could be improved. A direct source for quarterly changes in inventories, which is an important contributor to short-term deviation in the trend GDP growth rate, is lacking. There is no systematic, proactive process to monitor the ongoing representativeness of the samples of local units and products between rebases of the producer price index.

Comprehensive data reporting systems support the accuracy and reliability of the government finance and balance of payments statistics. However, although explanatory documentation exists, the lack of a table bridging the general government data in the ESA95 classification and the general government cash data on an administrative basis is impairing fiscal analysis; Germany publishes general government revenue, expenditure, and balance on an accrual basis every six months (ESA95). Monthly data are only disseminated on a cashbasis.

Germany is participating in the Coordinated Compilation Exercise for financial soundness indicators (FSIs). In 2006, as part of this exercise, the German authorities compiled a comprehensive set of FSI data and metadata. 


\begin{tabular}{|c|c|c|c|c|c|}
\hline \multicolumn{6}{|c|}{$\begin{array}{l}\text { Germany: Table of Common Indicators Required for Surveillance } \\
\text { (As of January } 30,2008 \text { ) }\end{array}$} \\
\hline & $\begin{array}{l}\text { Date of latest } \\
\text { observation }\end{array}$ & $\begin{array}{l}\text { Date } \\
\text { received }\end{array}$ & $\begin{array}{l}\text { Frequency } \\
\text { of } \\
\text { Data }^{6}\end{array}$ & $\begin{array}{l}\text { Frequency } \\
\text { of } \\
\text { Reporting }^{6}\end{array}$ & $\begin{array}{l}\text { Frequency } \\
\quad \text { of } \\
\text { Publication }^{6}\end{array}$ \\
\hline Exchange Rates & January 08 & $01 / 25 / 2008$ & $\mathrm{D}$ & $\mathrm{D}$ & $\mathrm{D}$ \\
\hline $\begin{array}{l}\text { International Reserve Assets and } \\
\text { Reserve Liabilities of the Monetary } \\
\text { Authorities }^{1}\end{array}$ & December 07 & January 08 & $\mathrm{M}$ & $\mathrm{M}$ & $\mathrm{M}$ \\
\hline Reserve/Base Money & December 07 & January 08 & M & $\mathrm{M}$ & $\mathrm{M}$ \\
\hline Broad Money & December 07 & January 08 & $\mathrm{M}$ & $\mathrm{M}$ & $\mathrm{M}$ \\
\hline Central Bank Balance Sheet & December 07 & January 08 & $\mathrm{M}$ & $\mathrm{M}$ & $\mathrm{M}$ \\
\hline $\begin{array}{l}\text { Consolidated Balance Sheet of the } \\
\text { Banking System }\end{array}$ & December 07 & January 08 & $\mathrm{M}$ & $\mathrm{M}$ & $M$ \\
\hline Interest Rates & December 07 & January 08 & $\mathrm{M}$ & $\mathrm{M}$ & $\mathrm{M}$ \\
\hline Consumer Price Index & November 07 & January 08 & $\mathrm{M}$ & $\mathrm{M}$ & $\mathrm{M}$ \\
\hline $\begin{array}{l}\text { Revenue, Expenditure, Balance and } \\
\text { Composition of Financing }{ }^{3}- \\
\text { General Government }^{4}\end{array}$ & June 07 & November 07 & $\begin{array}{l}\text { Semi- } \\
\text { annual }\end{array}$ & $\begin{array}{l}\text { Semi- } \\
\text { annual }\end{array}$ & $\begin{array}{l}\text { Semi- } \\
\text { annual }\end{array}$ \\
\hline $\begin{array}{l}\text { Revenue, Expenditure, Balance and } \\
\text { Composition of Financing }{ }^{3}-\text { Central } \\
\text { Government }\end{array}$ & December 07 & January 08 & Q & Q & Q \\
\hline $\begin{array}{l}\text { Stocks of Central Government and } \\
\text { Central Government-Guaranteed } \\
\text { Debt }^{5}\end{array}$ & December 07 & January 08 & $\mathrm{Q}$ & Q & Q \\
\hline External Current Account Balance & December 07 & January 08 & $\mathrm{M}$ & $\mathrm{M}$ & $\mathrm{M}$ \\
\hline $\begin{array}{l}\text { Exports and Imports of Goods and } \\
\text { Services }\end{array}$ & December 07 & January 08 & $\mathrm{M}$ & $\mathrm{M}$ & $\mathrm{M}$ \\
\hline GDP/GNP & Q4 07 & January 08 & $Q$ & $Q$ & Q \\
\hline Gross External Debt & $\mathrm{H} 107$ & November 07 & $\begin{array}{c}\text { Semi- } \\
\text { annual }\end{array}$ & $\begin{array}{c}\text { Semi- } \\
\text { annual }\end{array}$ & $\begin{array}{l}\text { Semi- } \\
\text { annual }\end{array}$ \\
\hline \multicolumn{6}{|c|}{$\begin{array}{l}\text { Includes reserve assets pledged or otherwise encumbered as well as net derivative positions. } \\
{ }^{2} \text { Both market-based and officially-determined, including discount rates, money market rates, rates on treasury bills, notes, } \\
\text { and bonds. } \\
{ }^{3} \text { Foreign, domestic bank, and domestic nonbank financing. } \\
{ }^{4} \text { The general government consists of the central government (budgetary funds, extra budgetary funds, and social security } \\
\text { funds) and state and local governments. } \\
{ }^{5} \text { Including currency and maturity composition. } \\
{ }^{6} \text { Daily (D); weekly (W); monthly (M); quarterly (Q); annually (A); irregular (I); and not available (NA). }\end{array}$} \\
\hline
\end{tabular}




\title{
INTERNATIONAL MONETARY FUND
}

\section{GERMANY \\ Staff Report for the 2007 Article IV Consultation Supplementary Information}

\author{
Prepared by the European Department \\ (In consultation with the Policy Development and Review Department) \\ Approved by Michael Deppler and Adnan Mazarei
}

February 20, 2008

This supplement provides an update on economic developments and prospects in Germany. With clearer evidence of weakening in the fourth quarter of 2007 and downward revision of global growth prospects, staff now forecasts German growth in 2008 at 1.5 percent, slightly below the projection in the staff report. The fiscal deficit is projected to rise correspondingly. Further write-downs have been reported at German banks and public sector financial commitments to capital injection have continued to increase. BaFin and the Bundesbank have reached a tentative agreement on coordinating supervision, but one that is not sufficiently far-reaching. The new information does not alter the thrust of the staff appraisal.

1. Staff projects a deceleration of GDP growth to $1 \frac{1}{2}$ percent in 2008 (Table 1). The growth projection for 2008 has been marked down from 1.7 to 1.5 percent, reflecting slower projected growth in the U.S. and Europe. Also, in line with view that the global environment will begin to improve in the later part of 2008, a modest upturn to 1.6 percent is projected for 2009.

\section{At this point, staff considers the risks to the forecast to be still tilted to the} downside, albeit modestly. While the revised forecast incorporates much of the downside risk embedded in the previous baseline, the tensions in the international financial system remain elevated (Figure 1). While the spreads on the inter-bank lending rates have moderated since the large liquidity injection by the ECB, the stress has shifted to credit markets, reflected in the credit default spreads. In particular, there have been continued disclosures of write-downs and losses by banks (as reported below). While larger banks have also been affected, the core of the problem continues to persist with some mid-sized banks. Recent news does not indicate if these financial developments have had implications for real growth over and above the tightening credit standards reported in the staff report. The greater risk, as the preliminary fourth quarter estimates warn, is a loss of consumer confidence (Figure 2). 


\section{The 2008 fiscal deficit is now expected to be slightly larger than originally} projected. With the revised GDP projections and assuming that automatic stabilizers are allowed to operate, staff now projects the overall deficit of the general government to reach 0.7 percent of GDP in 2008. The staff report had projected a shift from a balanced budget for the general government last year to an overall deficit of 0.6 percent of GDP this year, largely reflecting reductions in the corporate tax rate and the contributions towards unemployment insurance.

\section{Further write-downs have been reported at German banks, resulting in} increased public financial support. Additional write-downs have been reported at a number of banks, including West LB, IKB, Bayerische LB, and Commerzbank. This has added to the call on public money to support the public sector banks and at IKB (which though technically a private bank has KfW, a state-owned financial institution, as its principal shareholder). With the new developments, the cumulative support, including by KfW, implies a significant governmental commitment (exceeding $€ 11.75$ billion, or about $1 / 2$ percent of GDP, text table). Reportedly, the government is leading a further $€ 1.5$ billion package in a third effort to stabilize IKB. With write-downs possible, these commitments are set to increase. The continued reliance on public support for the ongoing bank rescues underscore staff's call for greater transparency, a resolution mechanism that injects incentives for prudent action, and, looking ahead, a more systematic restructuring of the banking sector.

\begin{tabular}{|c|c|c|c|}
\hline Bank & $\begin{array}{l}\text { Public Sector } \\
\text { Commitment }\end{array}$ & $\begin{array}{c}\text { Private and Public Banks \& } \\
\text { Banking Associations }\end{array}$ & Other \\
\hline $\begin{array}{l}\text { Sachsen } \\
\text { LB }\end{array}$ & $€ 2.75$ billion & $\begin{array}{c}€ 17.5 \text { billion (liquidity } \\
\text { support) }\end{array}$ & \\
\hline West LB & $€ 4$ billion * & $€ 1$ billion* & \\
\hline IKB & $€ 5$ billion** & $\begin{array}{c}€ 1.2 \text { billion million cash } \\
\text { infusion ** }\end{array}$ & $\begin{array}{c}\text { Additional } € 1.5 \text { billion } \\
\text { needed to cover additional } \\
\text { losses. }\end{array}$ \\
\hline
\end{tabular}

${ }^{*}$ Contingent on future losses on pool of $€ 23$ billion of structured products.

** Provisions taken by KfW against its risk exposure for a liquidity facility of $€ 8.1$ billion.

5. Pursuant to the instructions by the Ministry of Finance, BaFin and the Bundesbank have made some progress on their coordination efforts. Progress has been achieved on reducing duplication of supervisory visits by BaFin and the Bundesbank, in response to the perceived intrusiveness by banks of such visits. Yet, staff's reading of available public information is that the core issue of increasing accountability has not been tackled. Supervisory accountability would be best achieved, as noted in the staff report, by combining supervision and enforcement actions in either BaFin or the Bundesbank; alternatively, clear protocols for coordination would need to ensure accountability. 
Table 1. Germany: Basic Data

Total area

Total population (2005)

357,041 square kilometers

GDP per capita (2006)

82.4 million

US\$ 35,439

\begin{tabular}{|c|c|c|c|c|c|c|c|c|c|}
\hline & 2000 & 2001 & 2002 & 2003 & 2004 & 2005 & \multicolumn{2}{|c|}{$200620071 /$} & $20081 /$ \\
\hline & \multicolumn{9}{|c|}{ (Percentage change) } \\
\hline \multicolumn{10}{|l|}{ Demand and supply } \\
\hline Private consumption & 2.4 & 1.9 & -0.8 & 0.1 & 0.2 & -0.1 & 1.0 & -0.3 & 1.2 \\
\hline Public consumption & 1.4 & 0.5 & 1.5 & 0.4 & -1.5 & 0.5 & 0.9 & 2.0 & 1.3 \\
\hline Gross fixed investment & 3.0 & -3.6 & -6.1 & -0.3 & -0.2 & 1.0 & 6.1 & 5.5 & 1.5 \\
\hline Construction & -2.4 & -4.6 & -5.8 & -1.6 & -3.8 & -3.1 & 4.3 & 2.8 & 0.6 \\
\hline Machinery and equipment & 10.7 & -3.7 & -7.5 & 1.1 & 4.6 & 6.0 & 8.3 & 7.4 & 1.9 \\
\hline Final domestic demand & 2.3 & 0.4 & -1.4 & 0.1 & -0.2 & 0.3 & 2.0 & 1.4 & 1.3 \\
\hline Inventory accumulation 2/ & -0.1 & -0.9 & -0.6 & 0.5 & 0.0 & 0.1 & -0.1 & -0.3 & 0.1 \\
\hline Total domestic demand & 2.2 & -0.5 & -2.0 & 0.6 & -0.2 & 0.3 & 1.9 & 1.1 & 1.4 \\
\hline \multicolumn{10}{|l|}{ Exports of goods and } \\
\hline nonfactor services & 13.5 & 6.4 & 4.3 & 2.5 & 10.0 & 7.1 & 12.5 & 8.3 & 5.6 \\
\hline \multicolumn{10}{|l|}{ Imports of goods and } \\
\hline nonfactor services & 10.2 & 1.2 & -1.4 & 5.4 & 7.2 & 6.7 & 11.2 & 5.7 & 5.9 \\
\hline Foreign balance 2/ & 1.0 & 1.7 & 2.0 & -0.8 & 1.3 & 0.5 & 1.1 & 1.5 & 0.2 \\
\hline GDP & 3.1 & 1.2 & 0.0 & -0.3 & 1.1 & 0.8 & 2.9 & 2.5 & 1.5 \\
\hline \multirow[t]{2}{*}{ Output gap (In percent of potential GDP) } & 1.8 & 1.3 & -0.2 & -1.7 & -2.0 & -2.4 & -1.0 & 0.0 & -0.1 \\
\hline & \multicolumn{9}{|c|}{ (In millions of persons, unless otherwise indicated) } \\
\hline \multicolumn{10}{|l|}{ Employment and unemployment } \\
\hline Labor force & 41.9 & 42.1 & 42.2 & 42.3 & 42.7 & 42.6 & 43.2 & 43.3 & 43.3 \\
\hline Employment & 39.1 & 39.3 & 39.1 & 38.7 & 38.9 & 38.8 & 39.0 & 39.6 & 39.8 \\
\hline Unemployment 3/ & 3.1 & 3.2 & 3.5 & 3.9 & 4.2 & 4.6 & 4.2 & 3.6 & 3.5 \\
\hline Unemployment rate (in percent) 4 / & 6.9 & 6.9 & 7.7 & 8.8 & 9.2 & 10.6 & 9.8 & 8.4 & 8.1 \\
\hline & \multicolumn{9}{|c|}{ (Percentage change) } \\
\hline \multicolumn{10}{|l|}{ Prices and incomes } \\
\hline GDP deflator & -0.6 & 1.2 & 1.4 & 1.2 & 1.1 & 0.7 & 0.6 & 1.8 & 0.2 \\
\hline Consumer price index (harmonized) & 1.4 & 1.9 & 1.4 & 1.0 & 1.8 & 1.9 & 1.8 & 2.3 & 2.2 \\
\hline Average hourly earnings (total economy) & 2.8 & 2.7 & 2.0 & 1.7 & 0.3 & 1.0 & 1.1 & -0.2 & 0.6 \\
\hline Unit labor cost (industry) & -1.7 & 0.5 & 1.5 & -1.3 & -3.1 & -2.5 & -2.8 & -1.5 & -0.5 \\
\hline Real disposable income $5 /$ & 2.1 & 2.1 & -0.2 & 0.5 & 0.3 & 0.1 & 0.9 & 0.4 & 0.9 \\
\hline Personal saving ratio (in percent) & 9.2 & 9.4 & 9.9 & 10.3 & 10.4 & 10.5 & 10.5 & 11.1 & 10.8 \\
\hline
\end{tabular}

Sources: Deutsche Bundesbank; Federal Statistical Office; IMF, World Economic Outlook; IMF, International Financial Statistics; and staff estimates and projections.

1/ 2007 estimate, 2008 IMF staff projections.

2/ Growth contribution.

3/ National accounts definition

4/ Eurostat definition.

5/ Deflated by the national accounts deflator for private consumption. 
Table 1. Germany: Basic Data (concluded)

\begin{tabular}{|c|c|c|c|c|c|c|c|c|c|}
\hline & 2000 & 2001 & 2002 & 2003 & 2004 & 2005 & 2006 & $20071 /$ & $20081 /$ \\
\hline & \multicolumn{9}{|c|}{ (In billions of Euros, unless otherwise indicated) } \\
\hline \multirow{2}{*}{\multicolumn{10}{|c|}{$\begin{array}{l}\text { Public finances } 6 / 7 / \\
\text { General government }\end{array}$}} \\
\hline & & & & & & & & & \\
\hline Expenditure & 930 & 1,005 & 1,031 & 1,049 & 1,042 & 1,053 & 1,055 & 1,066 & 1,085 \\
\hline (In percent of GDP) & 45.1 & 47.6 & 48.1 & 48.5 & 47.1 & 46.9 & 45.4 & 44.0 & 43.8 \\
\hline Revenue & 957 & 945 & 953 & 962 & 958 & 977 & 1,017 & 1,065 & 1,068 \\
\hline (In percent of GDP) & 46.4 & 44.7 & 44.4 & 44.5 & 43.3 & 43.5 & 43.8 & 44.0 & 43.1 \\
\hline Overall balance & 27 & -60 & -78 & -88 & -85 & -79 & -37 & 0 & -17 \\
\hline (In percent of GDP) & 1.3 & -2.8 & -3.7 & -4.0 & -3.8 & -3.5 & -1.6 & 0.0 & -0.7 \\
\hline Structural balance & -25 & -54 & -62 & -69 & -62 & -55 & -27 & 0 & -21 \\
\hline (In percent of potential GDP) & -1.2 & -2.5 & -2.9 & -3.2 & -2.8 & -2.4 & -1.2 & 0.0 & -0.9 \\
\hline \multicolumn{10}{|l|}{ Federal government } \\
\hline Overall balance & 28 & -27 & -36 & -40 & -51 & -58 & -30 & -16 & -26 \\
\hline (In percent of GDP) & 1.4 & -1.3 & -1.7 & -1.8 & -2.3 & -2.6 & -1.3 & -0.7 & -1.0 \\
\hline General government debt & 1,211 & 1,224 & 1,278 & 1,358 & 1,430 & 1,489 & 1,533 & 1,533 & 1,550 \\
\hline (In percent of GDP) & 58.7 & 57.9 & 59.6 & 62.8 & 64.7 & 66.3 & 66.0 & 63.3 & 62.6 \\
\hline \multicolumn{10}{|l|}{ Balance of payments } \\
\hline Trade balance 8/ & 50.1 & 88.1 & 124.2 & 118.8 & 139.1 & 139.7 & 143.4 & 167.6 & 152.0 \\
\hline Services balance & -49.0 & -49.9 & -35.7 & -34.5 & -29.4 & -28.9 & -22.4 & -21.0 & -14.6 \\
\hline Net private transfers & -9.3 & -10.5 & -11.8 & -10.0 & -11.1 & -10.9 & -12.1 & -15.0 & -12.9 \\
\hline Net official transfers & -18.7 & -16.4 & -15.7 & -18.3 & -16.8 & -17.7 & -14.7 & -19.9 & -19.3 \\
\hline Current account & -35.2 & 0.4 & 43.0 & 40.9 & 94.9 & 103.1 & 117.2 & 135.0 & 129.6 \\
\hline (In percent of GDP) & -1.7 & 0.0 & 2.0 & 1.9 & 4.3 & 4.6 & 5.0 & 5.6 & 5.2 \\
\hline Foreign exchange reserves (e. o. p.) 9/ & 53.4 & 49.5 & 40.5 & 32.5 & 33.8 & 33.7 & 28.6 & 27.7 & $\ldots$ \\
\hline Monetary data & \multicolumn{9}{|c|}{ (Percentage change) } \\
\hline Money and quasi-money (M3) 10/ 11/ & -1.0 & 6.1 & & 3.5 & 2.2 & 5.1 & 4.7 & 10.6 & 10.6 \\
\hline \multirow[t]{2}{*}{ Credit to private sector $10 /$} & 5.8 & 3.2 & 0.9 & 0.0 & -0.2 & 2.1 & 3.5 & 1.8 & 3.2 \\
\hline & \multicolumn{9}{|c|}{ (Period average in percent) } \\
\hline \multicolumn{10}{|l|}{ Interest rates } \\
\hline Three-month interbank rate $12 /$ & 4.4 & 4.3 & 3.3 & 2.3 & 2.1 & 2.1 & 3.7 & 4.8 & 4.4 \\
\hline Yield on ten-year government bonds $12 /$ & 5.3 & 4.8 & 4.8 & 4.1 & 4.1 & 3.6 & 3.8 & 4.3 & 4.1 \\
\hline \multicolumn{10}{|l|}{ Exchange rates } \\
\hline Euro per US\$ (annual average) 12/ & 1.08 & 1.12 & 1.06 & 0.88 & 0.80 & 0.80 & 0.80 & 0.69 & 0.68 \\
\hline Nominal effective rate $(1990=100) 13 /$ & 100.0 & 101.5 & 104.7 & 112.6 & 115.8 & 114.7 & 116.6 & 119.7 & 120.0 \\
\hline Real effective rate $(1990=100) 14 /$ & 100.0 & 99.3 & 101.6 & 106.0 & 105.4 & 100.1 & 97.5 & 99.2 & $\ldots$ \\
\hline
\end{tabular}

6/ Data for federal government are on an administrative basis. Data for the general government are on a national accounts basis. Debt data are end-of-year data for the general government in accordance with Maastricht definitions.

7/ Government expenditure in 2000 includes, as a negative entry, the proceeds from the sales of mobile phone licenses of euro 50.8 billion (2.5 percent of GDP). The proceeds also affect the financial (but not structural) balances and the government debt.

$8 /$ Including supplementary trade items.

9/ From 1999 onward data reflect Germany's position in the euro area. Data for 2007 refer to December.

10/ Data for 2008 refer to the change from January 2007 to January 2008.

11/ Data reflect Germany's contribution to M3 of the euro area; data not shown for 2002 because of a series break.

12/ Data for 2008 refer to January.

13/ Data for 2008 refer to January

14/ Based on relative normalized unit labor cost in manufacturing. Data for 2007 refer to December. 
Figure 1. Germany: Financial Indicators
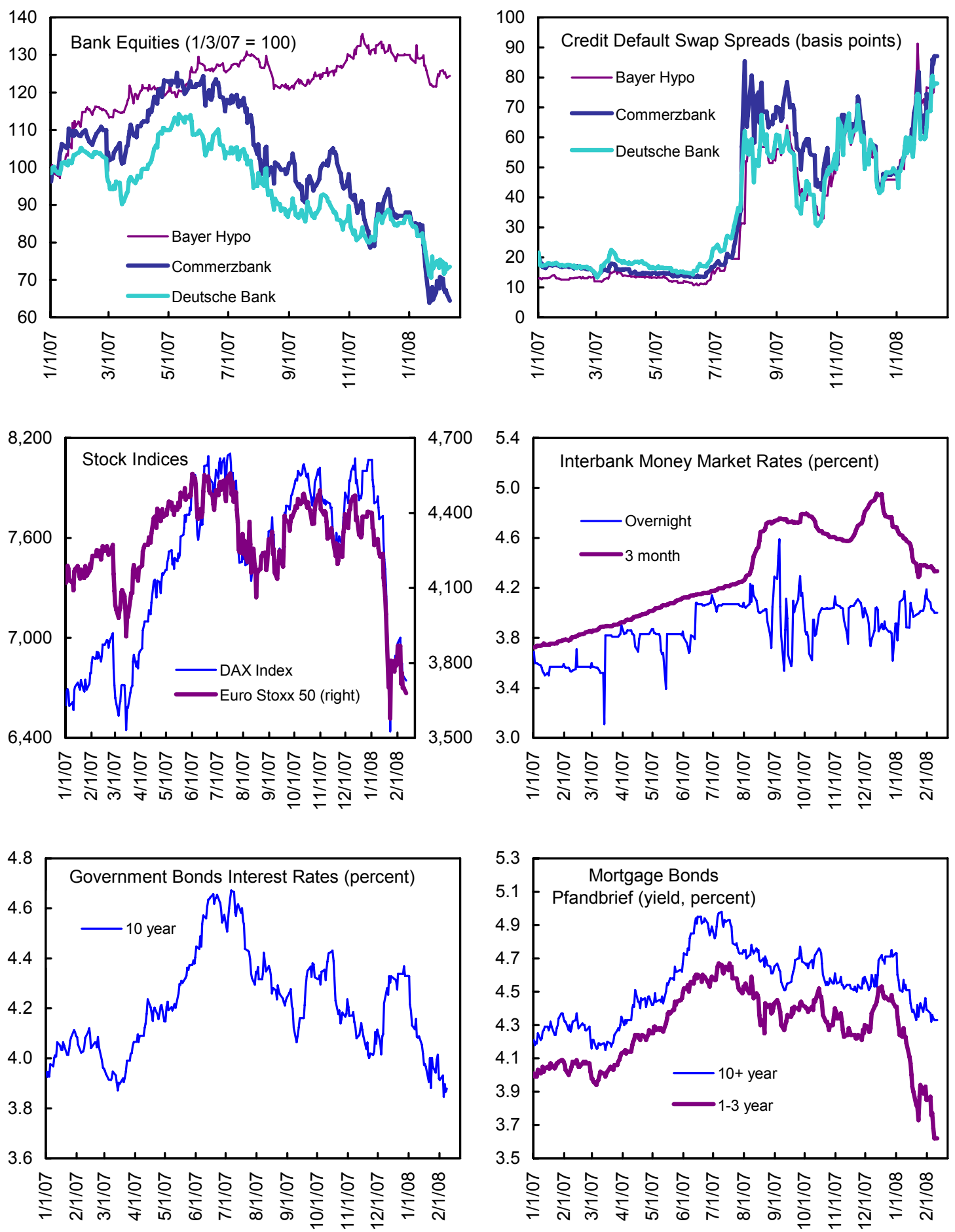

Source: Thomson Financial/DataStream. 
Figure 2. Germany: Sentiment, Orders, and Production

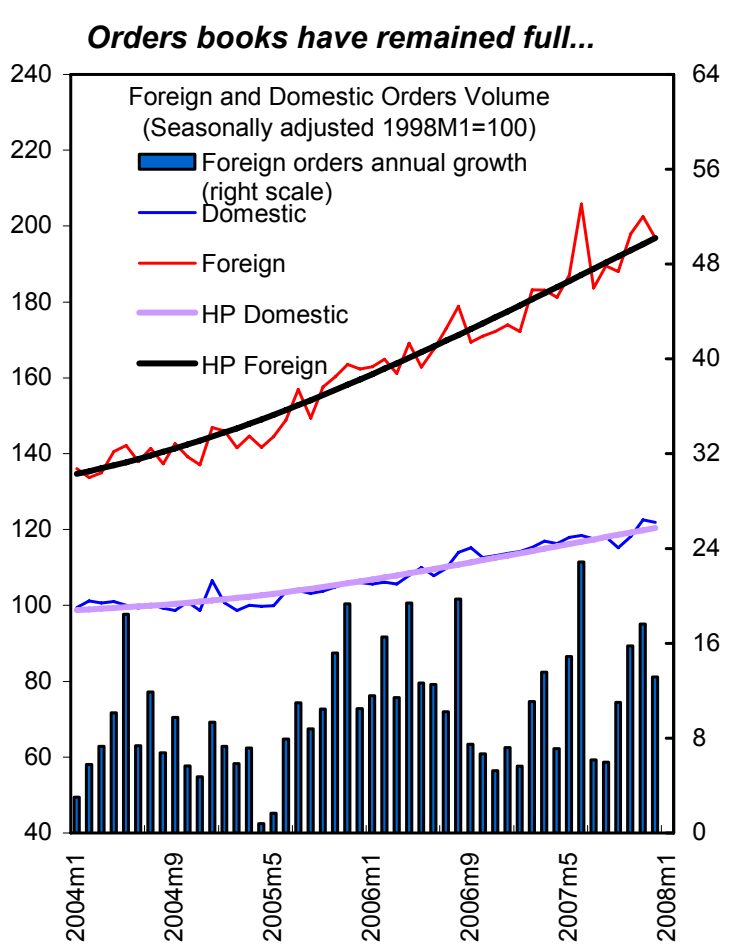

Business expectations are tapering off...

...but industrial production is expanding

Orders books have remained full..
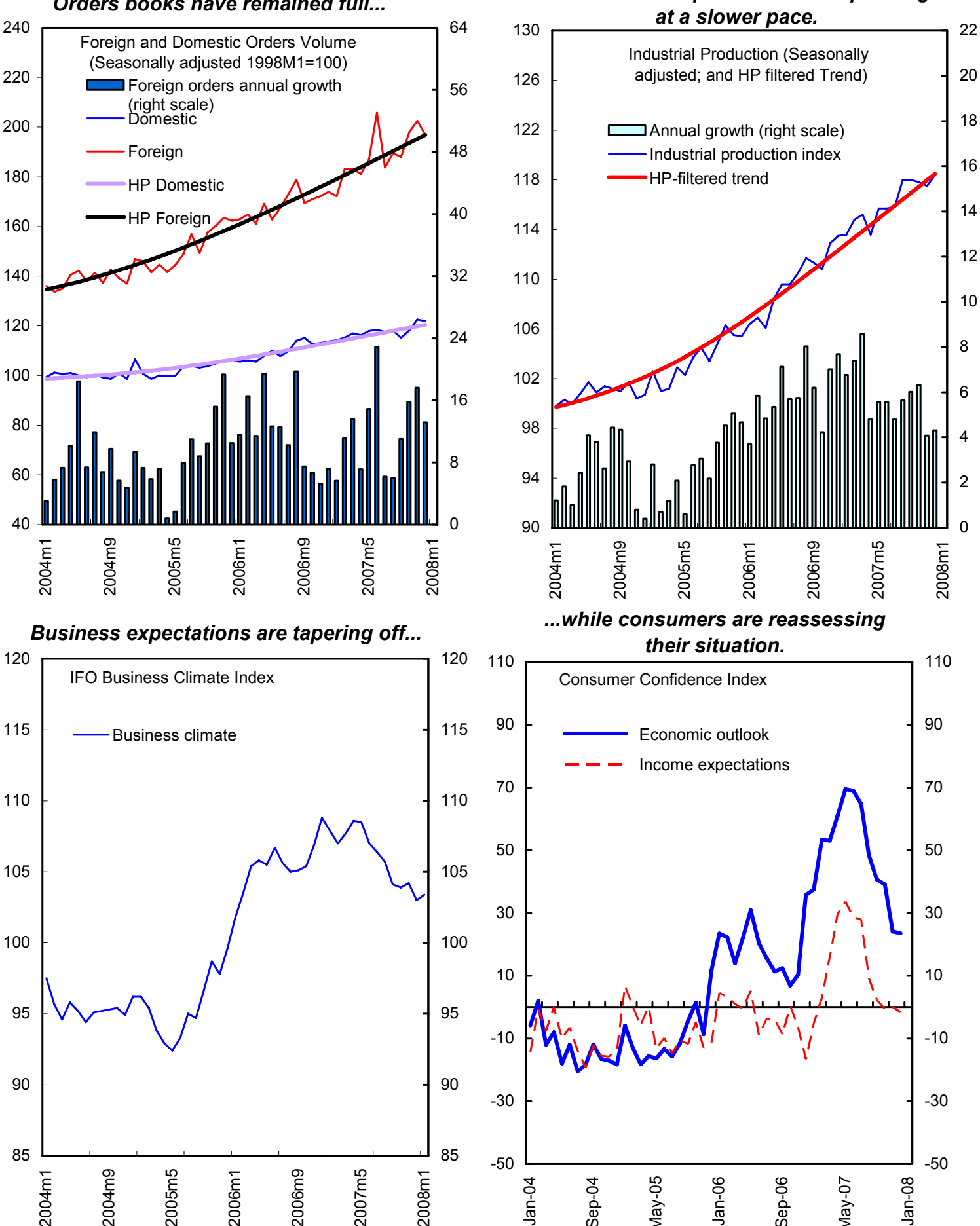

...while consumers are reassessing

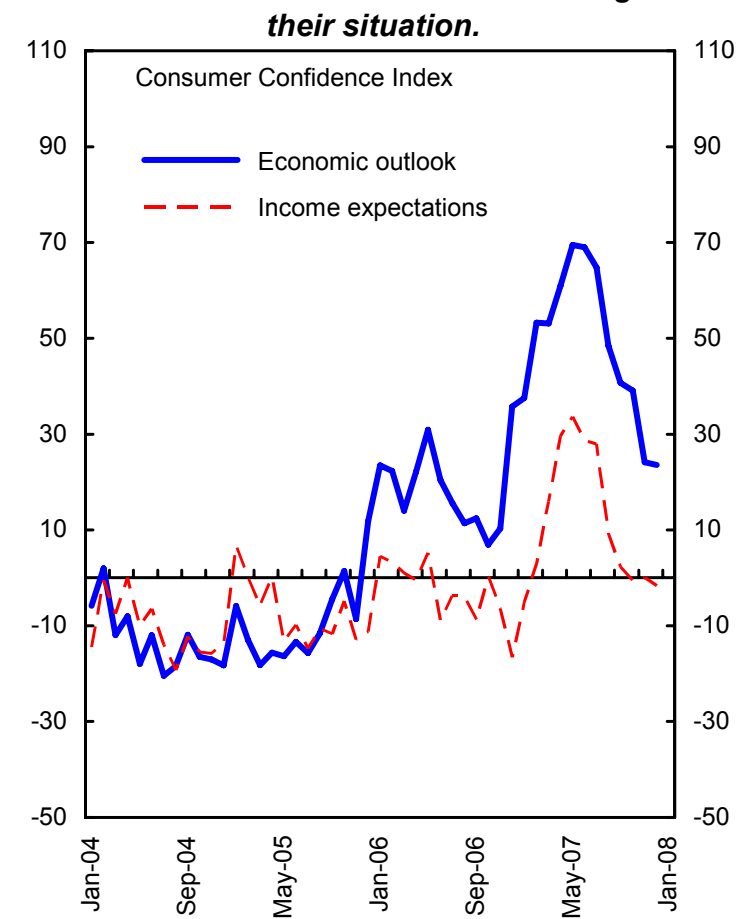

Source: Bundesbank, IFO institute, and GfK. 
Public Information Notice (PIN) No. 08/26

FOR IMMEDIATE RELEASE

February 27, 2008
International Monetary Fund $70019^{\text {th }}$ Street, NW

Washington, D. C. 20431 USA

\section{IMF Executive Board Concludes 2007 Article IV Consultation with Germany}

On February 22, 2008, the Executive Board of the International Monetary Fund (IMF) concluded the 2007 Article IV consultation with Germany. ${ }^{1}$

\section{Background}

Far reaching reforms have strengthened the German economy, but a weakening global cycle is dampening near-term growth prospects. Strong external competitiveness generated a robust recovery since 2004 with beneficial spillovers to Europe. A flurry of investment activity and a belated decline in unemployment have held up growth throughout 2007 despite the VAT hike. Policy credibility has been enhanced by determined fiscal consolidation.

GDP growth is projected to slow to 1.5 percent in 2008 from 2.5 percent in 2007. A slowing U.S. economy and weaker world trade is pulling down GDP growth given Germany's strong external dependence. To a lesser extent a strengthened euro and high oil prices are weighing down on output growth. On the positive side, a pick-up in consumption is helped by steady employment gains and limited wage moderation. Inflation is expected to slow moderately to 2.2 percent in 2008.

\footnotetext{
${ }^{1}$ Under Article IV of the IMF's Articles of Agreement, the IMF holds bilateral discussions with members, usually every year. A staff team visits the country, collects economic and financial information, and discusses with officials the country's economic developments and policies. On return to headquarters, the staff prepares a report, which forms the basis for discussion by the Executive Board. At the conclusion of the discussion, the Managing Director, as Chairman of the Board, summarizes the views of Executive Directors, and this summary is transmitted to the country's authorities. This PIN summarizes the views of the Executive Board as expressed during the February 22, 2008 Executive Board discussion based on the staff report.
} 
Productivity picked up in recent years, but sectoral trends are not comforting. Potential growth is estimated at 1/2-13/4 percent annually but will likely slip back on account of population aging unless total factor productivity growth rebounds. Labor productivity growth has accelerated only in the manufacturing sector. The much larger service sector has, however, shown little improvement, especially in real estate related and financial services. Moreover, shortages of skilled labor are pronounced and wide ranging, and particularly in the export oriented sector, health care and education, are holding back growth.

The financial sector has made much progress, but the recent turbulence highlighted unmet challenges. Long-standing concerns about low banking sector profitability and incentives for high-risk taking have now come to the fore. On the upside, considerable banking consolidation has already occurred and capital markets are growing rapidly, although from low levels.

Through a sustained effort Germany balanced its budget. Although the adjustment was helped by the upswing, policy efforts contributed in a major way. In 2006, the structural balance improved by more than one percentage point, a year ahead of the excessive deficit procedure schedule, and the adjustment continued steadily in 2007. This considerable up-front adjustment, and the ambitious goals to reach a primary surplus of $3^{1 / 2}$ percent of GDP by 2011 has improved public finances sustainability significantly. Nonetheless, longer-term fiscal challenges remain, as costs from health care will pose an increasing burden.

\section{Executive Board Assessment}

The Executive Directors welcomed the marked strengthening of Germany's economic performance of the past few years, and commended the consolidation and reform policies that have made these gains possible, including an impressive increase in employment and the best fiscal position since unification. Nonetheless, the reform agenda remains unfinished, and the near-term outlook is for slower growth and higher inflation, with the balance of risks modestly on the downside. Looking forward, Directors agreed on the need for the authorities to maintain short-term stability, especially in the financial sector, and to persist with the outstanding medium-term reform agenda.

Directors noted that the global economic slowdown, the strength of commodity prices, and financial tensions are having their impact on Germany. Fortunately, the relatively sound financial position of most banks and the low reliance of enterprises and households on credit have so far helped maintain normal lending, and while growth is slowing, it is expected to remain close to potential. At the same time, consumer and business confidence have weakened, credit standards have tightened recently, and some banks are facing continuing difficulties. In view of the yet unknown dimensions and fast-moving nature of the current global financial market turmoil, Directors urged the authorities to remain vigilant.

Directors observed that the fiscal position is moving from overall balance in 2007 to a moderate deficit in 2008. They generally considered that this fiscal loosening should help cushion the 
effects of the anticipated economic slowdown. Looking further ahead, Directors viewed fiscal sustainability as within reach, and they encouraged the authorities to move to complete the reform process and associated consolidation steps in order to secure it. In particular, achieving long-term fiscal sustainability will require tackling healthcare expenditures. Directors welcomed the authorities' intention to move to a fiscal framework centered on maintaining the overall deficit close to balance in cyclically-adjusted terms. They urged the authorities to press ahead with a second round of fiscal federalism reforms to improve incentives for prudent fiscal management.

Directors underscored that one of the authorities' key objectives must be to preserve confidence in the financial sector. While this has been achieved thus far by using public resources to rescue banks that faced insolvency, the fiscal costs of these rescues have mounted. Directors recommended adopting a bank resolution framework that is fully transparent and allows for quick resolutions, while providing stronger incentives for prudent management through the dilution of shareholders' equity in recapitalized or intervened banks.

Directors welcomed ongoing discussions to strengthen banking supervision. Looking ahead, they urged more frequent financial statements and more widespread use of International Financial Reporting Standards (IFRS) reporting to better capture off-balance-sheet activity. They considered that despite recent efforts, further measures are needed to enhance supervisory accountability and raise the quality of supervision. Directors therefore welcomed the recent protocol to improve coordination between the Bundesbank and the financial sector supervisory authority (BaFin).

Directors noted that the intensification of international financial integration suggests a need to restructure the German banking sector. Global competition is likely to continue to erode the traditional business models of banks that only serve targeted communities. Directors considered that bank restructuring should be guided by the goal of creating robust and sustainable banks, while allowing private capital to play a role.

Directors called on the authorities to safeguard their hard-won economic gains by pressing ahead with their medium-term reform agenda in the areas of labor markets, the general framework for investment, the financial sector, and fiscal policy. They pointed to the risks attached to any pause in the broader structural reform process for the achievement of long-term sustainability.

Directors recommended that a coordinated effort be made to raise Germany's growth potential. To that end, skills shortages need to be addressed by improving education and training, but also by encouraging the immigration of skilled workers. Directors welcomed efforts to rationalize active labor market programs and make child care more readily available. However, they cautioned that the new sectoral minimum wages could undermine work incentives and the success of Hartz IV labor market reforms. Directors called for enhancing the business climate by continuing to reduce taxes on capital and labor, but in a budget-neutral manner. 
Directors welcomed efforts to further develop capital markets, and underscored the importance of promoting transparency in corporate governance. They considered that rationalizing company supervisory board structures could help raise efficiency, and they saw a role for strengthening disclosure standards to improve internal and external discipline imposed on company managements. Directors cautioned against initiatives that would further empower insiders or render governance more complex.

Public Information Notices (PINs) form part of the IMF's efforts to promote transparency of the IMF's views and analysis of economic developments and policies. With the consent of the country (or countries) concerned, PINs are issued after Executive Board discussions of Article IV consultations with member countries, of its surveillance of developments at the regional level, of post-program monitoring, and of ex post assessments of member countries with longer-term program engagements. PINs are also issued after Executive Board discussions of general policy matters, unless otherwise decided by the Executive Board in a particular case. The staff report (use the free Adobe Acrobat Reader to view this pdf file) for the 2007 Article IV Consultation with Germany is also available. 


\section{Germany: Selected Economic Indicators}

\begin{tabular}{|c|c|c|c|c|c|}
\hline & 2003 & 2004 & 2005 & 2006 & $20071 /$ \\
\hline Economic activity and prices & \multicolumn{5}{|c|}{ (Change in percent, unless otherwise noted) } \\
\hline Real GDP & -0.3 & 1.1 & 0.8 & 2.9 & 2.5 \\
\hline Net exports 2/ & -0.8 & 1.3 & 0.5 & 1.1 & 1.5 \\
\hline Total domestic demand & 0.6 & -0.2 & 0.3 & 1.9 & 1.1 \\
\hline Private consumption & 0.1 & 0.2 & -0.1 & 1.0 & -0.3 \\
\hline Gross fixed investment & -0.3 & -0.2 & 1.0 & 6.1 & 5.5 \\
\hline Construction investment & -1.6 & -3.8 & -3.1 & 4.3 & 2.8 \\
\hline Gross national saving (percent of GDP) & 19.8 & 21.8 & 22.0 & 23.0 & 24.0 \\
\hline Gross domestic investment (percent of GDP) & 17.9 & 17.5 & 17.4 & 18.0 & 18.4 \\
\hline Labor force $3 /$ & 42.6 & 43.0 & 43.3 & 43.2 & 43.3 \\
\hline Employment 3/ & 38.6 & 38.8 & 38.7 & 39.0 & 39.7 \\
\hline Standardized unemployment rate (in percent) & 8.8 & 9.2 & 10.6 & 9.8 & 8.4 \\
\hline Unit labor costs (industry) & -1.3 & -3.1 & -2.5 & -2.8 & -1.5 \\
\hline GDP deflator & 1.2 & 1.1 & 0.7 & 0.6 & 1.8 \\
\hline Harmonized CPI index & 1.0 & 1.8 & 1.9 & 1.8 & 2.3 \\
\hline Public finance & \multicolumn{5}{|c|}{ (In percent of GDP) } \\
\hline General government balance 4/ & -4.0 & -3.8 & -3.5 & -1.6 & 0.0 \\
\hline Structural government balance & -3.2 & -2.8 & -2.4 & -1.2 & 0.0 \\
\hline General government gross debt & 62.8 & 64.7 & 66.3 & 66.0 & 63.3 \\
\hline Money and credit & \multicolumn{5}{|c|}{ (Change in percent over 12 months) } \\
\hline Private sector credit $5 /$ & 0.0 & -0.2 & 2.1 & 3.5 & 1.7 \\
\hline M3 5/ & 3.5 & 2.2 & 5.2 & 4.8 & 8.9 \\
\hline Interest rates & \multicolumn{5}{|c|}{ (In percent) } \\
\hline Three month money market rate $6 /$ & 2.3 & 2.1 & 2.1 & 3.7 & 4.6 \\
\hline Ten-year government bond yield $6 /$ & 4.1 & 4.1 & 3.6 & 3.8 & 4.3 \\
\hline Balance of payments & \multicolumn{5}{|c|}{ (In billions of euros, unless otherwise noted) } \\
\hline Exports $7 /$ & 770.0 & 846.5 & 915.9 & $1,042.2$ & $1,137.4$ \\
\hline Imports $7 /$ & 685.7 & 736.8 & 805.1 & 921.2 & 990.8 \\
\hline Trade balance (percent of GDP) & 5.5 & 6.3 & 6.2 & 6.2 & 6.9 \\
\hline Current account balance & 40.9 & 94.9 & 103.1 & 117.2 & 135.0 \\
\hline Current account (percent of GDP) & 1.9 & 4.3 & 4.6 & 5.0 & 5.6 \\
\hline Exchange rate & \multicolumn{5}{|c|}{ (Period average) } \\
\hline Euro per US dollar 8/ & 0.88 & 0.80 & 0.80 & 0.80 & 0.73 \\
\hline Nominal effective rate $(1990=100) 8 /$ & 112.6 & 115.8 & 114.7 & 114.9 & 120.0 \\
\hline Real effective rate $(1990=100) 9 /$ & 106.0 & 105.4 & 100.1 & 97.4 & 99.2 \\
\hline
\end{tabular}

Sources: Deutsche Bundesbank; IMF, IFS; IMF, World Economic Outlook; and staff projections.

$1 /$ Staff projections, if not otherwise indicated.

2/ Contribution to GDP growth.

3/ Domestic definition on a national accounts basis; according to new integrated system of economic accounts (ESA95).

4/ On a national accounts basis; according to new integrated system of economic accounts (ESA95).

5/ Data for 2007 refer to December 2007 M3 refers to Germany's contribution in the euro area.

6/ Data for 2007 refer to December 2007.

7/ Includes supplementary trade items.

8/ Data for 2007 refer to December 2007.

9/ Based on relative normalized unit labor cost in manufacturing. Data for 2007 refer to December. 


\section{Statement by Klaus Stein, Executive Director for Germany February 22, 2008}

We would like to thank the staff for a solid and thoughtful report and a set of insightful Selected Issues chapters. The report offers a balanced reflection of what my authorities considered to be a very constructive and candid dialogue during the consultations.

\section{Economic Situation}

The upswing of the German economy continued in 2007, supported by sound fundamentals. At 2.5 percent, real GDP grew considerably faster than initially expected. The unemployment rate declined by $1 \frac{1}{2}$ percentage points and external competitiveness remained strong. Furthermore, the general government posted a balanced budget for the first time since reunification and well ahead of schedule. Economic activity remained largely unaffected by the fiscal contraction, high oil prices, the euro appreciation, and the financial market turbulences. Meanwhile, inflationary pressures have clearly intensified and are expected to moderate only gradually.

The German economy is increasingly benefiting from the sustained adjustment efforts in the private sector and the broad and far-reaching reforms implemented over the past several years. Unfortunately, these reforms go largely unmentioned in Box 1 discussing previous policy implementation. They essentially comprise policy measures in the labor market and structural changes in the social security system, combined with a phased strategy of expenditure-based fiscal consolidation. At the same time, my authorities are well aware that further challenges lie ahead.

For 2008, the government projects economic activity to slow to 1.7 percent, which is somewhat above the staff projection. Growth will be driven mainly by private investment and a gradual strengthening in private consumption. Factors supporting consumption include higher employment, a pick-up in wage growth, and a further lowering of unemployment insurance contributions.

My authorities consider the risks to their forecast to be broadly balanced. They agree that developments in - international and domestic - financial markets give rise to particular uncertainty at this juncture. The economy appears, however, well-placed to weather tensions in this context, given high capacity utilization and a large order backlog in the manufacturing sector. Also, sentiment among businesses remains fairly positive and balance sheets are generally strong. Reliance of German businesses and households on external financing is relatively low. Moreover, available evidence points only to a moderate tightening of lending standards, also when compared to the rest of the euro area. Furthermore, growth of credit to businesses remains undiminished. That being said, vigilance is warranted going forward. 


\section{Fiscal Policy}

The steep reduction of the fiscal deficit ratio by $3 \frac{1}{2}$ percentage points since 2005 has been the result of buoyant revenues and sustained expenditure restraint, and was supported by improving cyclical conditions. The public spending ratio declined from $48 \frac{1}{2}$ percent to 44 percent of GDP over the last five years. This has been accompanied by efficiency-enhancing reforms strengthening both the tax structure and the composition of spending.

My authorities are keenly aware of the remaining challenge of securing long-term fiscal sustainability in the face of rising aging-related costs. As laid out in the latest Stability Program, Germany is going to keep the general government budget close to balance or in surplus, in line with the Stability and Growth Pact. As a part of this policy, the government intends to eliminate the deficit at the federal level by 2011. Among the reforms needed to ensure long-term sustainability are further measures to increase competition and transparency in the healthcare system.

The government is confident that the modest and temporary increase in the deficit expected this year is consistent with their proven strategy of growth-oriented fiscal consolidation. The temporary loosening is mainly the result of the coming-into-effect of the corporate income tax reform at the start of this year as well as the further round of reductions in unemployment insurance contributions, which will further foster employment. Both steps, along with the ongoing redirection of spending towards R\&D and education, will promote growth and thus fiscal consolidation down the road.

Indeed, the fiscal loosening that is already in the pipeline for $\mathbf{2 0 0 8}$ may prove opportune from the point of view of cushioning the incipient softening of economic activity. In the event of a stronger-than-expected downturn, automatic stabilizers would be the effective way to further support the economy.

Strong fiscal institutions are an important element in promoting prudent policies. The existing constitutional golden rule has shortcomings in that it leaves undue room for discretion and lacks symmetry between cyclical upswings and downturns. Building on the first round of federalism reforms of 2006, my authorities plan a revised deficit rule in a second round of reforms next year. They are of the view that, by ensuring a structurally balanced budget, the new rule is sufficiently ambitious. They are not convinced of the need for a contingent requirement of further belt-tightening as suggested by the staff. The government will continue to update its estimates of aging-related costs, including through its periodical sustainability report, and take corrective measures as needed. Moreover, it considers that the necessary trigger and quantification of a further belt-tightening requirement would be difficult to operationalize. 


\section{Structural Reforms}

The recent economic upswing is not just cyclical but also a reflection of the sustained restructuring efforts in the business sector and the far-reaching reforms undertaken in the labor market and in other areas. Mainly on account of the reforms, potential output growth is estimated to have risen over the last years by around a quarter percentage point to between $1 \frac{1}{2}$ and $13 / 4$ percent.

Looking ahead, further increases in trend economic growth are both achievable and necessary to confront the challenges posed by globalization and population aging. The most recent steps to this end include the above-mentioned lowering in social security contributions and the corporate income tax reform involving a steep reduction in effective tax rates to below 30 percent. These measures, along with the ongoing expansion of child care facilities, will help boost the investment climate, job incentives, and labor participation going forward.

At the same time, anchoring reforms in a sufficiently broad consensus and balancing efficiency considerations with social security concerns has served Germany well. In the government's view, there is a need to ensure that citizens increasingly share in the fruits of the upswing. That being said, Germany will stay the course in terms of economic policy and will continue the successful reforms of recent years. This does not rule out selective modifications in distinct cases.

On labor market issues, it is worth noting that the extension of the unemployment benefit period for elderly workers is being accompanied by targeted wage subsidies and strengthened job search requirements to protect job incentives. As regards wage bargaining, the continuing decline of the share of employees covered by collective wage agreements and the more adaptable working hour arrangements testify to increasing flexibility in labor markets.

On the issue of skills shortages, we would caution that the factors contributing to German emigration are difficult to gauge empirically. That said, the staff rightly points to the policy challenges involved. Besides the high priority the government places on improvements in education and training, selective steps were taken last fall to facilitate immigration, and further opening is being considered.

Finally, on the planned amendment to the Foreign Trade and Payments Act in the context of sovereign wealth fund investments, my authorities reiterate their firm commitment to undertake this in a manner that preserves Germany's long-standing reputation for openness to foreign capital. 


\section{Financial Sector}

Supervisory authorities continue to monitor financial sector developments closely. Risks related to international financial turbulence remain, and further writedowns cannot be ruled out. However, it is worth underscoring that the German banking system has remained robust and fully functional throughout the turmoil, notwithstanding the subprime-related capital injections that became necessary in a limited number of cases. A supporting factor has been bank profitability, which - while not yet on par with international levels - has improved appreciably over recent years.

The turmoil has highlighted the need for further restructuring of the Landesbank sector and for a review of individual business models. Besides the ongoing process of vertical integration, horizontal integration across regions is an option that attracts increasing attention. Indeed, the reform debate, including on opening the sector to private capital, has picked up considerable momentum of late. While outside of its purview, the federal government welcomes and supports this process.

As regards Deutsche Industriebank (IKB), losses on subprime-related investments necessitated two recapitalizations in 2007. A third package of support, including from the government, is currently being devised. Each time, difficult choices had and have to be made involving trade-offs between the evolving concerns of safeguarding financial stability, containing fiscal costs and moral hazard, and paving the way for selling the shares of IKB held by Kreditanstalt für Wiederaufbau (KfW).

As for the staff's reservations about relationship banking, we would note that the links between banks and large industrial enterprises were dramatically loosened in the nineties. Capital markets in Germany, including securitization markets, continue to grow at a high pace. As regards SMEs, even in the context of global competition, there are strong economic reasons for maintaining relationship banking, especially to reduce information asymmetries and to stabilize SME's access to loans over the business cycle.

On the bank resolution framework and possible revisions thereof, this issue should be viewed in a European context to ensure a level playing field across the EU. The relevant EU provision for bank insolvencies, the so-called winding-up-directive, is currently being reviewed.

As regards supervision, an agreement was reached this month on a revised guideline governing the respective competencies of the Deutsche Bundesbank and the BaFin. The revised guideline further specifies the tasks of the two agencies and directs their focus more clearly on the respective mandates of banking supervision on the one side and prudential enforcement and regulation on the other. The revision will thus go a long way towards clarifying the division of labor and eliminating any overlap. It should thereby 
further improve transparency and efficiency of banking supervision. By contrast, my authorities are not persuaded by the staff recommendation to consolidate bank supervision and enforcement in one of the two institutions. Leaving out BaFin would run counter to the basic principle of integrated financial supervision, a course that the authorities adopted only in 2002. Leaving out the Bundesbank would mean foregoing its extensive infrastructure and bank contacts and weakening it in the performance of its financial stability responsibility. Moreover, the issue thus far has been one of duplication of work, not of lack of accountability, as suggested by the staff.

On corporate governance, a proposal for a new EU statute for private companies similar to the Societas Europea statute is due to be put forward in the near future. It is also worth noting that the draft Risk Limitation Law mentioned by the staff may yet be modified to address concerns about legal uncertainties and undue constraints on shareholder rights.

Finally, on a more general note, my authorities attach great importance to addressing structural issues in international financial markets that may have contributed to excessive risk-taking. They support expedited efforts among relevant international bodies and supervisory authorities, in particular, to review and improve capital requirements and liquidity management standards and to increase transparency in areas such as off-balance sheet vehicles and rating agencies. 